\title{
Subsurface Structure of the East Bay Plain Ground-Water Basin: San Francisco Bay to the Hayward Fault, Alameda County, California
}

\author{
By R.D. Catchings ${ }^{1}$, J.W. Borchers ${ }^{1}$, M.R. Goldman ${ }^{1}$, G. Gandhok ${ }^{1}$, \\ D.A. Ponce ${ }^{1}$, and C.E. Steedman ${ }^{1}$
}

Open-File Report 2006-1084

2006

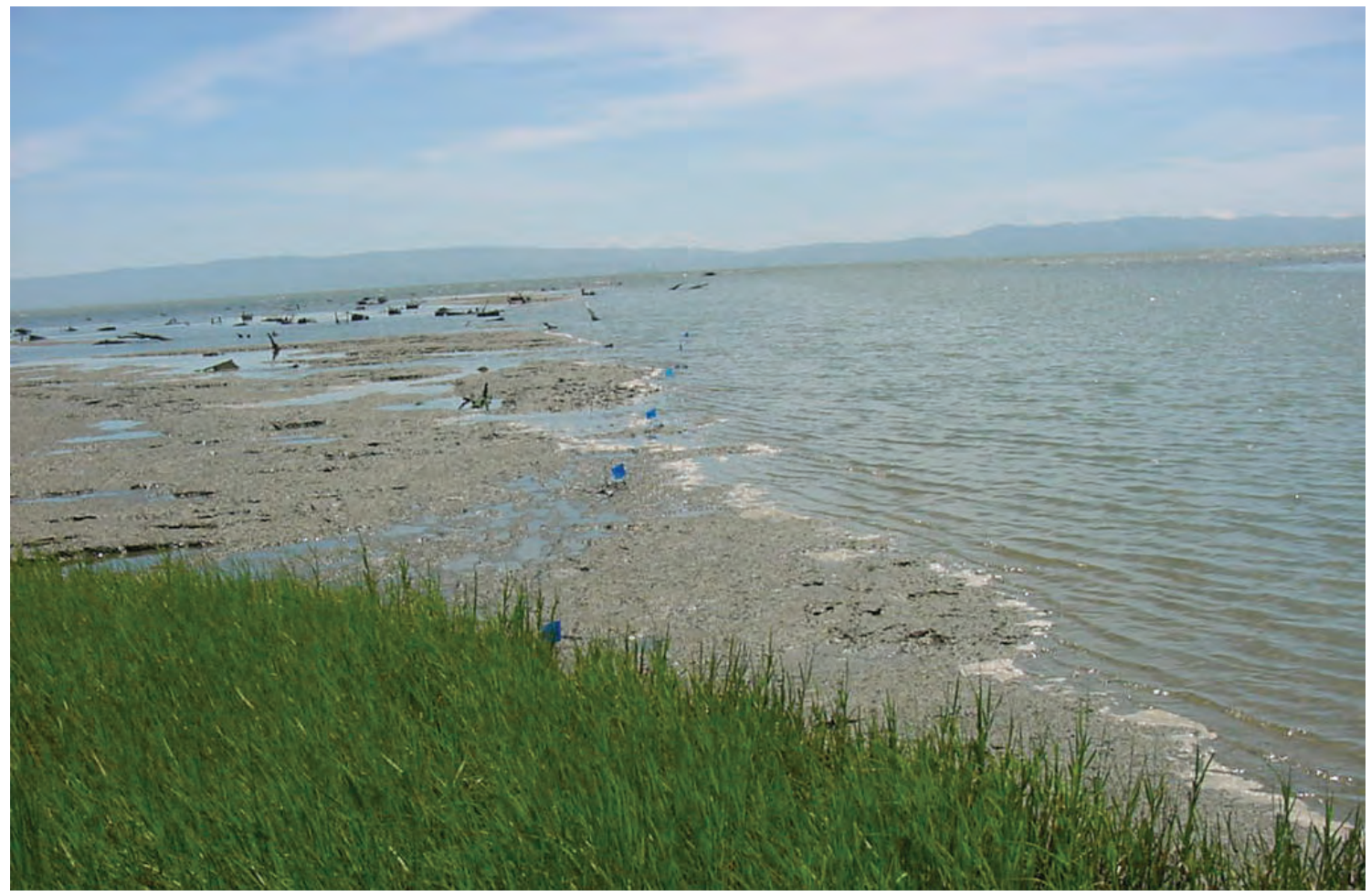

Any use of trade, firm, or product names is for descriptive purposes only and does not imply endorsement by the U.S. Government.

U.S. DEPARTMENT OF THE INTERIOR

U.S. GEOLOGICAL SURVEY

${ }^{1}$ U.S. Geological Survey, 345 Middlefield Rd, Menlo Park, CA 94025 


\section{Introduction}

The area of California between the San Francisco Bay, San Pablo Bay, Santa Clara Valley, and the Diablo Ranges (East Bay Hills), commonly referred to as the "East Bay", contains the East Bay Plain and Niles Cone ground-water basins (CDWR, 1967) (Fig. 1). The area has a population of 1.46 million (2003 US Census), largely distributed among several cities, including Alameda, Berkeley, Fremont, Hayward, Newark, Oakland, San Leandro, San Lorenzo, and Union City. Major known tectonic structures in the East Bay area include the Hayward Fault and the Diablo Range to the east and a relatively deep sedimentary basin known as the San Leandro Basin (Marlow et al., 1999; Stanley et al., 2002; Ponce et al., 2003) beneath the eastern part of the bay. Known active faults, such as the Hayward, Calaveras, and San Andreas pose significant earthquake hazards to the region, and these and related faults also affect ground-water flow in the San Francisco (SF) Bay area (Izbicki et al., 2003). Because most of the valley comprising the San Francisco Bay area is covered by Holocene alluvium or water at the surface, our knowledge of the existence and locations of such faults, their potential hazards, and their effects on ground-water flow within the alluvial basins is incomplete.

To better understand the subsurface stratigraphy and structures and their effects on ground-water and earthquake hazards, the U.S. Geological Survey (USGS), in cooperation with the East Bay Municipal Utility District (EBMUD), acquired a series of high-resolution seismic reflection and refraction profiles across the East Bay Plain near San Leandro in June 2002 (Fig. 2). In this report, we present results of the seismic imaging investigations, with emphasis on ground water.

\section{Geology and Tectonics}

The San Francisco Bay area is located within a relatively wide segment of the North American-Pacific plate boundary consisting of a number of active right-lateral, strike-slip fault zones, including the San Gregorio, San Andreas, Hayward-Rodgers Creek, Calaveras, and other smaller fault zones (Wallace, 1990; Graymer, 2000). The San Francisco Bay lies within a structural depression between the Diablo Range (East Bay Hills) to the east and the Santa Cruz Mountains to the west (Fig. 1). Within the structural depression, areas between the bay and the mountain ranges are largely covered by Quaternary alluvium (Graymer, 2000). On the eastern side of the bay, the alluvialcovered areas extend about 6 to $15 \mathrm{~km}$ from the bay to rock exposures in the Diablo Range. The alluvium and underlying sedimentary units consist largely of late Pleistocene to Holocene unconsolidated marine and continental deposits (Muir, 1993; Figuers, 1998). The marine deposits are largely estuarine mud and salt-marsh deposits, known as Young Bay Mud, Old Bay Mud or the Yerba Buena Mud (Sloan, 1992)), and other minor units (Trask and Rolston, 1951; Ross, 1977; Atwater et al, 1981; Rogers and Figuers, 1991; Sloan, 1992; Ch2M-Hill, Inc., 2000). The continental deposits are mostly coarse-grained stream-channel deposits and finer-grained flood-plain deposits (Sloan, 1992; Koltermann and Gorelick, 1992) that were deposited as coalescing alluvial fans of San Leandro, San Lorenzo, and Alameda Creeks and other drainages along the east side of the San Francisco Bay. Partly consolidated sedimentary rocks and deposits probably underlie the late Pleistocene continental and marine deposits in much of the southern East Bay Plain (Marlow and others, 1999; Izbicki and others, 2003).

In the region, basement rocks beneath the valleys are assumed to be the same as those found in the adjacent mountain ranges, which consist largely of Mesozoic Great 
Valley and Franciscan complexes, and overlying Tertiary and younger rocks (Howard, 1979; Graymer, 2000). In the study area, the Great Valley complex is principally composed of dismembered ophiolite and silicic volcanic rocks, which are overlain by Late Jurassic silicic tuff and tuffaceous sandstone, Late Jurassic to Early Cretaceous turbidites, and Late Cretaceous and Paleocene strata (Graymer, 2000). The Franciscan complex is composed of multiple rock types, including graywacke, metagraywacke, metachert, metabasalt, turbidites, sandstone, quartz diorite, and serpentinite (Graymer, 2000). The Tertiary strata consist of various sedimentary and volcanic rocks, which were probably deposited unconformably over the Mesozoic Rocks (Graymer, 2000). Within the East Bay Hills, late Cenozoic faulting and folding (Aydin, 1998; Unruh and Lettis, 1998) have deformed the sequence of rocks.

\section{Hydrogeology}

Historically, aquifer descriptions were extended into the East Bay Plain from the Niles Cone ground-water basin to the south (Brown and Caldwell, 1986; Maslonkowski, 1988). The four aquifers defined in the Niles Cone ground-water basin from shallowest to deepest are the Newark, Centerville, Fremont, and Deep aquifers. Generally, in the East Bay Plain sedimentary deposits that correlate with the Newark aquifer in the Niles Cone ground-water basin lie between depths of 9-40 m (30-130 ft) below land surface (CH2M HILL, 2000). Near the San Francisco Bay these deposits have been intruded by seawater. In the East Bay Plain sedimentary deposits that are correlative with the Centerville and Freemont aquifers in the Niles Cone ground-water basin are discontinuous lenses of sand and gravel interbedded with clays and silts between about 36 and $122 \mathrm{~m}(120-400 \mathrm{ft})$ below land surface. Most useable ground water is stored in the Centerville and Fremont equivalent deposits and in the Deep aquifer which lies between about 152 and $198 \mathrm{~m}$ (500-650 ft) below land surface in the study area. The aquifer system in the East Bay Plain consists of often discontinuous deposits of alluvial sand and gravel with some aeolian sand, separated by estuarine mud or fine-grained alluvial flood plain deposits.

In the East Bay Plain ground-water basin, the Deep aquifer is thickest and most continuous south of San Leandro (Izbicki et al., 2003). Luhdorff and Scalmannini (2003) proposed that a stratigraphic or structural transition partly restricts hydraulic interconnection within the Deep aquifer between the East Bay Plain and Niles Cone ground-water basins. They identified eight distinct coarse-grained stratigraphic units within the Deep aquifer underlying the southern East Bay Plain and within their transition zone. Sediments comprising the Deep aquifer in the study area may have been deposited further south, in the alluvial fan of Alameda Creek, and moved to the northwest by rightlateral motion on the Hayward Fault (Maslonkowski, 1988; Koltermann and Gorelick, 1992).

Considerable hydraulic connection between the two ground-water basins has been demonstrated only in the Deep Aquifer (Luhdorff and Scalmannini, 2003). Ground water in sediments overlying the Deep aquifer generally flows from east to west from the Oakland Hills to San Francisco Bay (SF Bay Regional Water Quality Board, 2004; $\mathrm{CH} 2 \mathrm{MHill}, 2000)$. Ground-water flow in the Deep aquifer may have a northerly component that has not been seen in the shallower aquifer system.

Knowledge of the aquifer system in the study area is principally derived from drillers' reports and associated bore hole geophysical logs collected from production and monitoring wells. Because of the complex depositional environment, where alluvial fan deposits interfinger with estuarine deposits, and because wells are spread widely over the 
ground-water basin, it is difficult to correlate stratigraphy from well to well. Highresolution seismic imaging methods, like those presented in this report, combined with well-log data, provide a means to more closely correlate stratigraphic horizons and structural complexity that affect ground-water flow across the East Bay Plain.

\section{Seismic Survey}

\section{Data Acquisition}

In June 2002, the USGS acquired a 6-km-long, high-resolution seismic transect from the SF Bay to the Hayward fault (Fig. 1). Most $(\sim 4.2 \mathrm{~km})$ of the transect trended along San Lorenzo (SL) Creek, and the remaining segments were acquired along accessible paths toward the Hayward Fault (Fig. 2). For ease of processing the data, we divided the transect into six nearly linear segments or "profiles", here referred to as profiles SL-1 through SL-6. Acquisition parameters are presented in Table 1.

We used a combination of Betsy-Seisgun ${ }^{\mathrm{TM}}$ blasts, down-hole explosive blasts, and dropped weights as seismic sources. Betsy Seisgun ${ }^{\mathrm{TM}}$ blasts consisted of 400 -grain shotgun blanks in 0.3-m-deep holes, and down-hole explosive sources consisted of $\sim 150$ g $(1 / 3 \mathrm{lb}$.) pentolite explosives in 2-m-deep holes. Along paved streets near the Hayward fault, we used an accelerated weight-drop source, borrowed from Lawrence Livermore National Laboratory. The combination of seismic sources was spaced at 5-m increments along the seismic profile, except where cultural features limited their use.

The data were recorded using an array of four Geometrics Strataview ${ }^{\mathrm{TM}} \mathrm{RX} 60$ seismographs, each with 60 active channels (240 total active channels), mated to $40-\mathrm{Hz}$, single-element, Mark Products L-40A ${ }^{\mathrm{TM}}$ vertical geophones. The geophones were spaced at 5-m increments along the profile and co-located (1-m separation) with the seismic sources. Shot timing was determined electronically at the seismic source when a hammer, used to trigger the seisgun, electrically closed contact with the Betsy Seisgun ${ }^{\mathrm{TM}}$, sending an electrical signal to the seismograph. The weight-drop source similarly triggered the seismographs electronically upon impact with the ground surface. For the explosive source shots, seismographs and seismic sources were manually triggered, and timing was determined from up-hole times at the co-located geophones.

Data were acquired using a shoot-through acquisition technique, whereby recording sensors remained stationary as shots were fired through the actively recording array. Typically, shots were fired through one-half to three-quarters of the active array before the southwestern 60 channels were moved to the northeastern end of the active array. This process of moving the seismic array was utilized for all segments of the profile that were longer than $1200 \mathrm{~m}$. Three seconds of data were recorded for sources generated by the Betsy Seisgun ${ }^{\mathrm{TM}}$ and weight-drop, and five seconds of data were recorded for the explosive shots. The data were recorded in SEG-2 format on the hard drive of Geometrics ${ }^{\mathrm{TM}}$ seismographs during field acquisition and were later transferred to 4-mm tape in SEG-Y format for long-term storage.

Table 1. Acquisition parameters for Profiles SL-1 though SL-6. Distances are relative to the first and last geophone. Cumulative length does not include recording lapse.

\begin{tabular}{|c|c|c|c|c|c|c|c|}
\hline Profile \# & Orientation & $\begin{array}{c}\text { Length of } \\
\text { geophone } \\
\text { profile }(\mathrm{m})\end{array}$ & $\begin{array}{c}\text { Length of } \\
\text { shot point } \\
\text { profile }(\mathrm{m})\end{array}$ & $\begin{array}{c}\text { No. } \\
\text { of } \\
\text { shots }\end{array}$ & $\begin{array}{c}\text { No. of } \\
\text { CDPs }\end{array}$ & $\begin{array}{c}\text { Max } \\
\text { fold }\end{array}$ & $\begin{array}{c}\text { Cumulative } \\
\text { Length (m) } \\
\text { (geophones) }\end{array}$ \\
\hline Profile SL1 & SW-NE & 2833 & 2799 & 538 & 1153 & 168 & 2833 \\
\hline Profile SL2 & W-E & 729 & 708 & 148 & 311 & 148 & 3562 \\
\hline Profile SL3 & W-E & 673 & 673 & 130 & 287 & 130 & 4235 \\
\hline Profile SL4 & SW-NE & 270 & 260 & 26 & 107 & 26 & 4505 \\
\hline
\end{tabular}




\begin{tabular}{|l|l|l|l|c|c|c|c|}
\hline Profile SL5 & SW-NE & 284 & 244 & 39 & 95 & 39 & 4789 \\
\hline Profile SL6 & SW-NE & 574 & 574 & 115 & 233 & 115 & 5363 \\
\hline
\end{tabular}

\section{Shot-point and Receiver Locations and Theoretical Fold}

Prior to acquiring the seismic data, geophone and shot locations were surveyed using a measuring tape. After acquiring the data, geodetic positions of every shot location and every $20^{\text {th }}$ geophone position were determined using either a differential Global Positioning System (GPS) or an Electronic Distance Measurement ((EDM) instrument. Surveyed locations may be accurate to within $0.05 \mathrm{~m}$. Locations of geophones that were not surveyed were interpolated from the surveyed geophone locations.

Lateral variations in the elevations of shot points and receivers may cause inaccuracies when stacking reflection data and when determining velocities if the variations are not included in processing. We have accounted for these elevation variations during data processing but we include profile geometries in Appendices A-G for reference. Graphical displays of the profile geometries are also presented, including plots of shot and geophone elevations, shot and geophone lateral variations, and fold (Figs. 3-8).

\section{Profile SL 1}

Profile SL 1 was oriented southwest-northeast, and it extended $2833 \mathrm{~m}$ along the southern side of San Lorenzo Creek from the San Francisco Bay to Washington Avenue (Fig. 2). A total of 538 shots were fired, with 43 shot points not utilized due to cultural features. Geophone elevations varied by about $8 \mathrm{~m}$ over a distance of about $2833 \mathrm{~m}$ (Fig. 3a), and the geophone array deviated laterally from a linear array by $89 \mathrm{~m}$ (Fig. 3b), which is about a $3 \%$ lateral variation relative to profile length. Shot point elevations varied about $7 \mathrm{~m}$ along the 2799-m-long shot point array (Fig. 3c) and varied laterally from a linear array by about $88 \mathrm{~m}$ (Fig. 3d). For purposes of stacking the reflection data, fold along SL-1 varied with distance along the profile because of changes in geophone placement described above. Maximum fold was greater than 160, decreasing to 1 at the ends of profile SL-1 (Fig. 3e).

\section{Profile SL 2}

Profile SL-2 was oriented west to east, and it extended $729 \mathrm{~m}$ along the northern side of San Lorenzo Creek from Washington Avenue to Embers Way at the I-880 freeway. Three RX-60 seismographs with 159 active channels were used to record the data. A total of 148 shots were fired, with five shot points not utilized due to cultural features. Geophone elevation varied by about $4 \mathrm{~m}$ along the 729-m-long profile (Fig. 4a), and the geophone array varied laterally by about $58 \mathrm{~m}$ relative to a linear array of the shot points, an approximately $8 \%$ lateral variation relative to profile length (Fig. $4 \mathrm{~b}$ ). Shot point elevations varied by about $4 \mathrm{~m}$ along the 708-m-long shot point array (Fig. 4c), and shot points varied laterally from a linear array by about $44 \mathrm{~m}$ (Fig. 4d), a 6\% variation. Theoretical stacking fold along SL-2 varied smoothly along the profile because of the stationary recording array, with a maximum fold of 148 near the center, decreasing to one at the ends of the profile (Fig. 4e).

\section{Profile SL 3}

Profile SL 3 was oriented west to east, and it extended $673 \mathrm{~m}$ along the northern side of San Lorenzo Creek from the I-880-freeway overpass at Hesperian Boulevard to 
the Southern Pacific railroad tracks at Lewelling Boulevard. Three RX-60 seismographs with 144 active channels were used to record the data. A total of 130 shots were fired, with 14 shot points were not utilized due to cultural features. Geophone elevation varied across the 673-m-long profile by about $2.5 \mathrm{~m}$ (Fig. 5a), and the geophone array varied from a linear array by about $47 \mathrm{~m}$ (Fig. 5b), an approximate $7 \%$ lateral variation relative to the profile length. Shot point elevations also varied by about $2.5 \mathrm{~m}$ along the $673-\mathrm{m}-$ long shot point array (Fig. 5c), with shot points varying laterally relative to a linear array by about $46 \mathrm{~m}$ (Fig. 5d). Fold along SL-3 varied smoothly along the profile because of the stationary recording array. Maximum fold was 130 near the center of the profile, decreasing to one at the ends of the profile (Fig. 5e).

\section{Profile SL 4}

Profile SL 4 was oriented southwest-northeast, originating at the Southern Pacific railroad tracks (north of Lewelling Blvd.) and extending northeast $270 \mathrm{~m}$ across the athletic fields of San Lorenzo High School. One RX-60 seismograph with 55 live channels was used to record the data. A total of 26 shots were fired, with 29 shot points not utilized within the confines of the school's football field. Geophone elevation varied across the 270-m-long survey by about $1.6 \mathrm{~m}$ (Fig. 6a), and the geophone array varied laterally relative to a linear array by about $1 \mathrm{~m}$ (Fig. 6b), approximately a $0.4 \%$ lateral variation relative to the profile length. Shot point elevations also varied about $2 \mathrm{~m}$ along the 260-m-long shot point array (Fig. 6c), with a lateral variation relative to a linear array of about $1.2 \mathrm{~m}$ (Fig. 6d). Fold along SL-4 varied considerably across the profile because of the missing shot points across the football field (Fig. 6e). A maximum fold of 26 was obtained near the middle of the profile. However, much of the western half of the profile had a fold of only three due to the unused shot points. Fold decreased to one at the ends of the profile.

\section{Profile SL 5}

Profile SL 5 was oriented southwest to northeast (Fig. 2). The profile originated at Ashland Avenue and the southwest entrance to Edendale Park, and it extended $284 \mathrm{~m}$ northeast to the northeastern corner of Edendale Park. One RX-60 seismograph with 58 active channels was used to record the data. A total of 39 shots were fired, with 19 shot points not utilized due to cultural features such as sprinklers and a children's playground. Geophone elevation varied by about $1.3 \mathrm{~m}$ along the 284-m-long profile (Fig. 7a), with the geophone array varying laterally from a linear array by about $2.1 \mathrm{~m}$ (Fig. 7b), an approximately $0.7 \%$ lateral variation relative to the profile length. Shot point elevations also varied about $1.3 \mathrm{~m}$ along the 244-m-long shot point array (Fig. 7c), with lateral variation relative to a linear array of about $2 \mathrm{~m}$ (Fig. $7 \mathrm{~d}$ ) or about $0.8 \%$. Fold along SL-5 varied smoothly across the profile because of the stationary recording array. Maximum fold was 39 near the center of the profile, decreasing to one at the ends of the profile (Fig. 7e).

\section{Profile SL 6}

Profile SL 6 was oriented southwest to northeast (Fig. 2). The profile extended $574 \mathrm{~m}$ from near the corner of E-14 ${ }^{\text {th }}$ Street and $163^{\text {rd }}$ Avenue (on the northwestern side of $163^{\text {rd }}$ Avenue) to Liberty Street at the I-580 freeway. Two RX-60 seismographs with 117 active channels were used to record the data. A total of 115 weight-drop sources were used, with two shot points not utilized due to cultural features. Geophone elevation varied by about $11 \mathrm{~m}$ across the 574-m-long profile (Fig. 8a), with the geophone array 
varying laterally relative to a linear array by about $2.5 \mathrm{~m}$ (Fig. $8 \mathrm{~b}$ ), approximately a $0.4 \%$ lateral variation relative to profile length. Shot point elevations also varied by about 11 $\mathrm{m}$ along the 574-m-long shot point array (Fig. 8c), and the shot point array varied relative to a linear array by about $4.9 \mathrm{~m}$ (Fig. 8d). Fold along SL-6 varied smoothly along the profile because of the stationary recording array. Maximum fold was 115 near the center of the array, decreasing to one at the ends of the profile (Fig. 8e).

\section{Seismic Imaging Method}

Because of the shoot-through acquisition method, we developed reflection and refraction images from the same data. Individual profiles were analyzed separately, but we present them here as a composite image so that the images can be seen in the context of the entire seismic profile. However, we describe specifics of data processing and inversion for each profile so that possible anomalies and artifacts can be pointed out.

\section{Data Analysis}

First-arrival refractions from usable seismograms were used to develop a P-wave tomographic velocity model of the shallow subsurface along each seismic profile. We used a modified version of an algorithm by Hole (1992), whereby we parameterize the starting model into 5-m by 5-m vertical and horizontal grids. As a check on the validity of the model, we utilized multiple starting models, all of which yielded similar final models. Velocities were measured at depths ranging from about $3 \mathrm{~m}$ below the ground surface (bgs) to maximum depths of about $120 \mathrm{~m}$ bgs. The depth of velocity imaging was largely determined by the maximum distance that clear first arrivals could be observed on the seismic records. Because of the noisy urban environment, clear first arrivals were typically observed to lateral distances of about $600 \mathrm{~m}$ or less from the source. For greater depths, velocities needed for seismic reflection stacking were determined using semblance, parabolic methods, and apriori knowledge of the local geology, derived by combining borehole and empirical data. We also used the inversionderived velocities to convert the reflection time images to depth images and to migrate the seismic reflection images.

\section{Seismic Refraction Images}

\section{Composite Velocity Image}

Near-surface velocities along profile SL-1 vary from $900 \mathrm{~m} / \mathrm{s}$ near the northeastern end of the profile to about $1400 \mathrm{~m} / \mathrm{s}$ at the southwestern end of the profile (Fig. 9). At approximately $100 \mathrm{~m}$ depth, velocities range from $1800 \mathrm{~m} / \mathrm{s}$ on the southwestern end of the profile to about $2000 \mathrm{~m} / \mathrm{s}$ on the northeastern end. Near-surface velocities along SL-1 are generally greater near the bay (southwest end of the profile) than those farther to the northeast. Because P-wave velocities in relatively thick sequences of unconsolidated and saturated sediments are typically at least $1500 \mathrm{~m} / \mathrm{s}$ (Nur, 1982; Schon, 1996), we can use the $1500 \mathrm{~m} / \mathrm{s}$ velocity contour (white contour, Fig. 9) to infer lateral variations in the top of continuously water-saturated sediments along the profile. However, because the model is a smoothed average over vertical and lateral distances of about 10 to $15 \mathrm{~m}$ ( 2 to 3 grids), the $1500 \mathrm{~m} / \mathrm{s}$ velocity contour probably infers relative depth variations, not the exact depths of continuously saturated sediments. Another factor that may influence the velocity variations is the presence of faults, which can result in shallower depths to the $1500 \mathrm{~m} / \mathrm{s}$ velocity contour in saturated rocks 
(Mooney and Ginzburg, 1986). Thus, some of the vertical variation in the depth of the $1500 \mathrm{~m} / \mathrm{s}$ velocity contour may be related to faulting and fracturing.

On the basis of variations in the depth of the $1500 \mathrm{~m} / \mathrm{s}$ velocity contour across the East Bay Plain, we suggest that, generally, the water table is shallowest near the San Francisco Bay and deepens toward the Hayward Fault. However, there are several local variations in the depth of the $1500 \mathrm{~m} / \mathrm{s}$ contour that suggest the depth to the water table changes or shallow-depth sediments have been disrupted by faulting. Along profile SL-1, two distinct zones with relatively greater depths to the $1500 \mathrm{~m} / \mathrm{s}$ velocity contour are centered near meters 250 and 2300 of the seismic profile. These zones are also seen as anomalies in the seismic reflection images, and as discussed below, the zones may correlate with significant shallow-depth faulting.

Velocities along profile SL-2 vary from $800 \mathrm{~m} / \mathrm{s}$ at the surface to $1900 \mathrm{~m} / \mathrm{s}$ at a depth of about $100 \mathrm{~m}$ (Fig. 9). Across much of the seismic profile, the depth to the 1500 $\mathrm{m} / \mathrm{s}$ velocity contour does not vary significantly. However, there is appreciable variation in the depth of the $1500 \mathrm{~m} / \mathrm{s}$ contour near the ends of the seismic profile. We cannot rule out possible edge effects, resulting from too few raypaths at depth near the ends of the array, as causing the depth variations near the ends of the profile. However, as discussed below, we conclude that the apparent variation in the depth of the $1500 \mathrm{~m} / \mathrm{s}$ velocity contour near the northeast end of the profile is probably due to lateral changes in structure and/or composition. Generally, near-surface velocities are lower along profile SL-2 relative to those along profile SL-1, particularly along the northeastern section of the profile. Lateral complexities in the higher-velocity (deeper) strata $(>1500 \mathrm{~m} / \mathrm{s})$ are probably related to lateral variations in composition or structure along the profile.

Near-surface velocities along profile SL-3 vary from $800 \mathrm{~m} / \mathrm{s}$ on the southwest end of the profile to $1100 \mathrm{~m} / \mathrm{s}$ on the northeast end. At depths of about $80 \mathrm{~m}$, maximum velocities are about $1850 \mathrm{~m} / \mathrm{s}$ along the profile (Fig. 9). The $1500 \mathrm{~m} / \mathrm{s}$ velocity contour, which is outlined in white on the velocity image, varies from about $20 \mathrm{~m}$ to about $35 \mathrm{~m}$ deep along the seismic profile, with the greatest depth occurring near the northeast end of the profile. The greater depths to the $1500 \mathrm{~m} / \mathrm{s}$ contour near the northeast end of the profile may be related to raypath edge effects, but we suggest that the greater depths are related to structural or compositional variations based on two observations. First, the $1500 \mathrm{~m} / \mathrm{s}$ velocity contour deepens more than $100 \mathrm{~m}$ southwest from the northeast end of profile SL-3. Ray-path edge effects are unlikely to occur that far from the end of the profile, especially at shallow depths. Second, the $1500 \mathrm{~m} / \mathrm{s}$ contour is deep at both the northeastern end of profile SL-3 and the southwestern end of profile SL-4. Higher velocities $(>1700 \mathrm{~m} / \mathrm{s})$ also show appreciable lateral variation, suggesting considerable structural or compositional variation at depth.

Due to the relatively short length of profile SL-4, we obtained velocities to maximum depths of only $40 \mathrm{~m}$. Near-surface velocities along profile SL-4 vary from 800 $\mathrm{m} / \mathrm{s}$ to $1100 \mathrm{~m} / \mathrm{s}$ (Fig. 9), with the highest near-surface velocities near meter 100 of the seismic profile. The relatively higher near-surface velocities are likely due to soils with high water content on the San Lorenzo High School football field, which recently had been seeded and was being watered during data acquisition. From the near surface to about $40 \mathrm{~m}$ below land surface, velocities increase to about $2000 \mathrm{~m} / \mathrm{s}$, which are high relative to those along profiles SL-1 through SL-3. For velocities greater than about 1200 $\mathrm{m} / \mathrm{s}$, the velocity contours largely dip to the southwest, suggesting more structural or compositional complexity toward the southwest. In particular, the $1500 \mathrm{~m} / \mathrm{s}$ velocity contour dips southwestward, and it largely coincides with the $1500 \mathrm{~m} / \mathrm{s}$ velocity contour near the northeastern end of profile SL-3. These similar variations in velocity near the 
adjoining ends of the two profiles suggest structural or compositional anomalies in this vicinity of the East Bay Plain.

The relatively short length of profile SL-5 $(\sim 300 \mathrm{~m})$ limited our velocity measurements to maximum depths less than $50 \mathrm{~m}$ along the profile. Near-surface velocities range from 700 to $900 \mathrm{~m} / \mathrm{s}$, with minor lateral variation in velocity or depth of velocity contours (Fig. 9). The velocity gradient in the upper $20 \mathrm{~m}$ is high, reaching 1500 $\mathrm{m} / \mathrm{s}$ at about $18 \mathrm{~m}$ and about $2000 \mathrm{~m} / \mathrm{s}$ at depths less than $40 \mathrm{~m}$. Low-velocity sediments $(<1500 \mathrm{~m} / \mathrm{s})$ do not vary appreciably in depth along the profile, but higher-velocity ( $>$ $1500 \mathrm{~m} / \mathrm{s}$ ) sediments vary considerably in depth along the profile, with the greatest depths near the southwestern end of the profile. The appreciable lateral variations in velocity below the $1500 \mathrm{~m} / \mathrm{s}$ contour may suggest structural complexity below depths of about 20 m.

The approximately 575-m length of profile SL-6 allowed us to determine velocities to a maximum depth of approximately $75 \mathrm{~m}$ (Fig. 9). Near-surface velocities vary from about 800 to about to $1100 \mathrm{~m} / \mathrm{s}$ in the upper $10 \mathrm{~m}$, with higher near-surface velocities near meter 150 and between meters 400 and 450. High-velocity gradients in the upper $25 \mathrm{~m}$ are prominent, with maximum velocities of about $1800 \mathrm{~m} / \mathrm{s}$. The thickness of near-surface, low-velocity $(<1800 \mathrm{~m} / \mathrm{s})$ deposits does not vary significantly along the profile, although there is slightly greater thickness to the southwest. However, the depth of higher-velocity deposits $(>1800 \mathrm{~m} / \mathrm{s})$ varies appreciably along the profile; high-velocity deposits are significantly deeper on the southwest end of the profile.

Collectively, the velocity profiles suggest that low-velocity, unconsolidated, unsaturated sediments $(<1500 \mathrm{~m} / \mathrm{s})$ are relatively thin $(<5 \mathrm{~m})$ near the San Francisco Bay, and they deepen ( $40 \mathrm{~m}$ maximum) toward the center of the East Bay Plain (west of Washington Avenue). From near Washington Avenue eastward, the low-velocity sediments decrease in thickness toward the East Bay Hills to about $15 \mathrm{~m}$ or less. Velocities of $1500 \mathrm{~m} / \mathrm{s}$ and higher follow a similar trend across the East Bay Plain, with lateral variations in velocity occurring abruptly. Such large changes in the velocity structure, occurring over relatively short distances, probably indicate tectonic disruption of sediments that may affect the ground-water-flow system.

\section{Seismic Reflection Data Processing}

In seismic-reflection data processing, we followed procedures similar to those outlined by Brouwer and Helbig (1998). Processing steps included geometry installation, independent trace editing, timing corrections, elevation static corrections, AGC, bandpass filtering, F-K filtering (or surgical muting), velocity analysis (from refractions, semblence, and borehole-velocity measurements), NMO correction, stretch muting, common-depth-point (CDP) stacking, post-stack AGC, post-stack bandpass filtering, and post-stack deconvolution. Principal parameters used in processing are shown in Table 2 . For migrated images, we applied pre-stack Kirchoff depth migration after velocity analysis.

In trace editing, noisy traces (due to cultural noises) or redundant traces (due to geometry) were removed from the shot gathers before stacking or migrating. Elevation statics, migration, and velocity analysis were accomplished, in part, using the tomographic velocity model from each profile. For velocities at depths in excess of those determined by the tomography velocity model, we used parabolic methods, and we inferred velocities based on lithologic logs from nearby wells and velocity-depth (pressure) relations (Carmichael, 1989). 
Table 2. Processing parameters for the San Leandro seismic profiles.

\begin{tabular}{|l|l|l|l|}
\hline Parameter & SL-1 & SL-2 & SL-3 \\
\hline CDP Spacing & $2.3-2.5 \mathrm{~m}$ & $1.7-2.5 \mathrm{~m}$ & $2.3-2.5 \mathrm{~m}$ \\
\hline $\begin{array}{l}\text { AGC } \\
\text { Prestack }\end{array}$ & $500 \mathrm{~ms}$ & $500 \mathrm{~ms}$ & $500 \mathrm{~ms}$ \\
Poststack & $100 \mathrm{~ms}$ & $100 \mathrm{~ms}$ & $100 \mathrm{~ms}$ \\
\hline $\begin{array}{l}\text { Bandpass Filtering } \\
\text { Notch }\end{array}$ & $60,120 \mathrm{~Hz}$ & $60,120 \mathrm{~Hz}$ & $60,120 \mathrm{~Hz}$ \\
$\begin{array}{l}\text { Prestack } \\
\text { Poststack Low } \\
\text { Poststack High }\end{array}$ & $15-30-400-800 \mathrm{~Hz}$ & $15-30-400-800 \mathrm{~Hz}$ & $15-30-200-400 \mathrm{~Hz}$ \\
\hline $\begin{array}{l}\text { FK Filter (min-max } \\
\text { veloc, min-max freq., k- } \\
\text { space restrict.) }\end{array}$ & $50-100-200-400 \mathrm{~Hz}$ & $\begin{array}{l}15-30-400-800 \mathrm{~Hz} \\
50-100-200-400 \mathrm{~Hz}\end{array}$ & $\begin{array}{l}15-30-400-800 \mathrm{~Hz} / \mathrm{s}, 1 \mathrm{~Hz}, \\
50-100-200-400 \mathrm{~Hz}\end{array}$ \\
\hline $\begin{array}{l}\text { Migration (freq., } \\
\text { aperture, angle) }\end{array}$ & $400 \mathrm{~m} / \mathrm{s}, 800 \mathrm{~m} / \mathrm{s}, 1 \mathrm{~Hz}$, & $90 \mathrm{~m} / \mathrm{s}, 800 \mathrm{~m} / \mathrm{s}, 1 \mathrm{~Hz}$, \\
\hline \multicolumn{2}{|l}{$50000 \mathrm{~Hz}, 400 \mathrm{~m}, 30 \mathrm{deg}$} & $400 \mathrm{~Hz}, 200 \mathrm{~m}, 60 \mathrm{deg}$ & $400 \mathrm{~Hz}, 200 \mathrm{~m}, 30 \mathrm{deg}$ \\
\hline
\end{tabular}

\begin{tabular}{|l|l|l|l|}
\hline Parameter & SL-4 & SL-5 & SL-6 \\
\hline CDP Spacing & $2.4-2.6 \mathrm{~m}$ & $2.4-2.6 \mathrm{~m}$ & $2.4-2.8 \mathrm{~m}$ \\
\hline AGC & & $500 \mathrm{~ms}$ & $500 \mathrm{~ms}$ \\
$\quad \begin{array}{l}\text { Prestack } \\
\text { Poststack }\end{array}$ & $500 \mathrm{~ms}$ & $100 \mathrm{~ms}$ & $100 \mathrm{~ms}$ \\
\hline Bandpass Filtering & $100 \mathrm{~ms}$ & & \\
$\quad$ Notch & $27 \mathrm{~Hz}$ & $27 \mathrm{~Hz}$ & $27 \mathrm{~Hz}$ \\
$\begin{array}{l}\text { Prestack } \\
\text { Poststack Low }\end{array}$ & $15-30-400-800 \mathrm{~Hz}$ & $15-30-400-800 \mathrm{~Hz}$ & $15-30-400-800 \mathrm{~Hz}$ \\
Poststack High & $50-100-200-400 \mathrm{~Hz}$ & $15-30-400-800 \mathrm{~Hz}$ & $15-30-400-800 \mathrm{~Hz}$ \\
\hline $\begin{array}{l}\text { FK Filter (min-max } \\
\text { veloc, min-max freq., k- } \\
\text { space restrict.) }\end{array}$ & $90 \mathrm{~m} / \mathrm{s}, 800 \mathrm{~m} / \mathrm{s}, 1 \mathrm{~Hz}$, & $90 \mathrm{~m} / \mathrm{s}, 800 \mathrm{~m} / \mathrm{s}, 1 \mathrm{~Hz}$, & $90 \mathrm{~m} / \mathrm{s}, 800 \mathrm{~m} / \mathrm{s}, 1 \mathrm{~Hz}$, \\
\hline $\begin{array}{l}\text { Migration(freq., } \\
\text { aperture, angle) }\end{array}$ & $600 \mathrm{~Hz} 50 \%$ & $600 \mathrm{~Hz} 50 \%$ & $600 \mathrm{~Hz} 50 \%$ \\
\hline
\end{tabular}

\section{Seismic Reflection Images}

We developed seismic reflection images along each of the six profiles by stacking secondary arrivals from the same shot gathers used to obtain the velocity image. We present composite seismic reflection images of the East Bay Plain transect with relatively low frequencies (30-60-200-400 Hz; Figs. 10 and 17a), relatively high frequencies (50100-200-400 Hz; Fig. 11), and intermediate frequencies (25-50-400-800 Hz; Fig. 17b). The lower-frequency stacks image to greater depths, and the higher-frequency stacks more clearly resolve the upper few hundred meters of the subsurface. Thus, some of the images show structure at depths of $1500 \mathrm{~m}$ or more, and other images show details of the shallow (upper few hundred meters) subsurface.

\section{Reflection Images: Profiles SL-1 Through SL-6}

Numerous sub-horizontal reflections are imaged in the upper few hundred meters at relatively low frequencies (30-60-200-400 Hz) on the SL profiles (Fig. 10). These reflections correlate with sequences of sediments (sand, clay, and gravel) known to underlie the East Bay Plain (Izbicki et al., 2003), but at relatively low frequencies, thin 
layers may be averaged and represented on reflection images as a single reflector. Furthermore, the reflection images do not discriminate between individual layers of coarse or fine-grained sediment; instead, such layers are probably indicated as groups or sequences of sediments containing mixed textures. The lateral continuity of the more prominent reflectors suggests that the same or similar stratigraphic layers or groups of layers persist across the East Bay Plain from the bay to the Hayward fault, although these layers may differ laterally in content, such as grain size, degree of consolidation, and amount of tectonic disruption. Vertical offsets of stratigraphic layers and folding of layers in the reflection images suggest that the layers are disrupted at multiple locations along the SL profiles. Apparent disruptions in the stratigraphic layers occur along profile SL-1 between meters 200-400 and meters 1900-2800 and along much of profile SL-6. At these locations, the reflection image is distorted by diffractive energy. Such disruption is often associated with faults, but might result from the non-linear geometry of the seismic array in specific locations. Several observations argue against non-linear geometric distortion. First, the location and degree of disruption of the layers do not coincide with the location and degree of curvature of the seismic profile (see Figs. 2-8). Second, vertical offsets in the sedimentary layers persist beyond the areas of curvature of the seismic profile. Third, there are similar disruptions in the sedimentary layers in areas where the seismic array is linear. Fourth, the most disrupted reflectors coincide with zones of relatively low velocities; fault zones and low P-wave velocities have been well documented elsewhere (Mooney and Ginzburg, 1986; Catchings, 1999; Catchings et al., 2002). On the basis of these observations, we suggest that the disrupted layers and the corresponding degraded reflection images result from vertical and horizontal offsets (faulting) and fracturing. The layered strata are disrupted in all depth ranges from the very near surface to at least the base of the layered strata, as inferred by the reflectivity pattern of the deeper seismic images.

The thickness of layered strata is highly variable along the seismic transect. For example, within 1300 m of the San Francisco Bay (profile SL-1), strong reflections persist to depths in excess of $800 \mathrm{~m}$, which is the greatest depth of such reflections observed along the seismic transect. Northeast of meter 1300 of profile SL-1, the deep $(800 \mathrm{~m})$ reflectors abruptly terminate, and from meter 1300 to about meter 1900 of profile SL-1, the sub-horizontal reflectors become progressively shallower (from $\sim 800$ to about $400 \mathrm{~m}$ deep) along an apparent series of faults. Because these reflectors do not dip significantly to the southwest, they probably were not deposited in an existing basin but were vertically offset after deposition. At depths of about $400 \mathrm{~m}$ and less, some of the more prominent reflectors are offset vertically at multiple locations along the seismic transect.

Rocks underlying the layered strata are largely non-reflective, with depth to the top of the non-reflective rocks ranging from about 200 to $800 \mathrm{~m}$ along the East Bay Plain seismic transect. These non-reflective rocks are probably Franciscan basement rocks, but on the basis of reflectivity alone, we cannot be certain that some of the non-reflective rocks below $800 \mathrm{~m}$ are not sediments. However, if the rocks below about $800 \mathrm{~m}$ depth are sediments, they are not sub-horizontally layered and probably dip at high angles to account for the lack of reflectivity.

\section{Higher-Frequency Stacks}

To provide more details of the upper $500 \mathrm{~m}$ along the seismic transect, we developed a higher-frequency (50-100-200-400 Hz) reflection image (Fig. 11). Because the frequency of the seismic wave determines, in part, which layers (minimum thickness) are imaged, higher-frequency seismic data can image thinner layers when all other 
parameters are the same. Whereas the lower-frequency seismic sections image a series of thin layers as a single reflector, multiple thin layers can be resolved with the higherfrequency data. The general formula (Dobrin and Savit, 1988) used to determine the minimum layer thickness needed to generate reflections is the one-quarter-wavelength criteria, where wavelength is:

$\lambda=v / f$, where $v=$ velocity $(\mathrm{m} / \mathrm{s}), \lambda=$ wavelength $(\mathrm{m})$, and $f=$ frequency $(\mathrm{Hz})$ : and the radial width or length of the reflector is related to the Fresnel zone (W):

$\omega=v / 4(\operatorname{sqrt}(t / f)$, where $t$ is time $(\mathrm{sec}), v=$ velocity $(\mathrm{m} / \mathrm{s})$ :

Only stratigraphic layers that are about one-fourth of $\lambda$ and $\omega$ will likely generate reflections seen in figure 11 . The minimum thickness of the reflectors varies with velocity, but assuming dominant frequencies of $100 \mathrm{~Hz}$ and average velocities of 1500 $\mathrm{m} / \mathrm{s}$, as determined in the shallow subsurface along this transect, the shallow reflectors imaged in figure 11 are at least $4 \mathrm{~m}$ thick and $5 \mathrm{~m}$ long. Thus, layers thinner than about 4 $\mathrm{m}$ and those with radii less than $5 \mathrm{~m}$ cannot be resolved with our data. Both the high- and low-frequency stacks show similar strata, but the high-frequency stack provides more detail, from which we correlate well logs and known stratigraphy.

\section{Well Logs}

Several wells with lithologic and/or electric borehole geophysical logs are located within $1 \mathrm{~km}$ of the seismic transect (Fig. 12). Most of these wells are several hundred meters from the seismic profile. To compare the borehole geophysical logs with the seismic images, we projected the wells perpendicularly onto the seismic profile (Figs. 12 and 13). The stratigraphy should be generally consistent over distances of several hundred meters, although the exact stratigraphic sequence and depths to stratigraphic horizons beneath the seismic profile may differ somewhat from those determined in the wells because the wells and the seismic transect are not co-located.

We identified 27 deep wells ( $>400 \mathrm{ft}$ deep) along the seismic transect with available geophysical and/or lithologic logs. We plotted five geophysical logs from wells close to the seismic profile on the seismic sections. Wells 3S3W-14K12, 3S3W-13M4, and $3 \mathrm{~S} 3 \mathrm{~W}-13 \mathrm{D} 7$ project perpendicularly to profile SL-1 at approximately meters 570 , 1010 , and 1435, respectively, of the profile. Well 3S2W-7E1 projects to profile SL-2 at about meter 660 , and well 3S2W-7G12 projects to profile SL-4 at about meter 145 . Both spontaneous potential and resistivity logs are available for each well; however, for display purposes, we include only the short-normal resistivity logs on the seismic sections. We plotted seven lithologic logs from wells close to the seismic profile on the seismic sections. Wells 3S3W-14F1, 3S3W-14K2, 3S3W-14G2, 3S3W14J2, 3S3W12R1, project perpendicularly to profile SL-1 at meters $485,525,640,840,2570$, respectively, of the profile. Well $3 \mathrm{~S} 3 \mathrm{~W}-12 \mathrm{H} 1$ projects perpendicularly to the trend of the seismic profile at about meter 425 of profile SL-2, and well 3S2W-6R2 projects perpendicularly to profile SL-5 at about meter 175 .

The projected wells are not uniformly spaced along the seismic transect. There is only one nearby well along profile SL-5 and no wells near profile SL-6, making it more ambiguous to correlate known lithologies and these seismic images. Along profiles SL-1 through SL-4, we correlate the seismic images with well-log data and infer lateral variations in sedimentary sequences that include major aquifers (Fig. 13). However, we emphasize that our interpretation is non-unique, particularly between the various seismic profiles and along profile SL-4, where the seismic image is degraded due to missing shot points. On the basis of our correlations, we suggest that the sedimentary sequences that contain the aquifer materials in some places are continuous across the East Bay Plain, but 
some layers are disrupted (vertically offset) in multiple locations. Although these sedimentary sequences appear continuous across much of the East Bay Plain, we emphasize that their compositions (grain size, lithology, etc.) may vary significantly along the seismic profile. These sedimentary sequences also vary in depth, but the general trend is for sequences to shallow to the northeast. Sub-horizontal reflectors below the Deep Aquifer along profiles SL-1 and SL-6 suggest that additional thick sedimentary sequences underlie the Deep aquifer, but the water-yielding potential of these sediments cannot be obtained from the seismic data. The deeper sedimentary sequences appear to be of limited lateral extent and do not extend across the entire East Bay Plain. The termination of sub-horizontal reflections along profile SL-6 suggests that most sedimentary sequences containing aquifers terminate west of the surface trace of the Hayward fault.

\section{Gravity Data and Models}

For this investigation, D.A. Ponce acquired gravity data along the East Bay Plain seismic transect (Table 3 ) that compliment a regional gravity data set published by Ponce (2001). Along the East Bay Plain seismic transect, gravity measurements were made every $40 \mathrm{~m}$ (every $8^{\text {th }}$ seismic shot point) to help constrain the seismic observations (Fig. 14). The raw data were reduced to provide the Bouguer (complete and simple) anomaly, which ranges from about -2.6 mgal near the Bay to about 20.5 mgal near the Hayward fault. The overall gravity field increases to the northeast along the seismic transect, but there are local anomalies superimposed on the regional trend, suggesting structural variations in the upper few kilometers.

We developed a 2-D gravity model along the East Bay seismic transect (Figs. 15), and we compare our model with another gravity model (Ponce et al., 2003) adjacent to the East Bay Plain seismic transect (Figs. 14 and 16). We used densities similar to those of Ponce et al. (2003), with Franciscan basement, the San Leandro gabbro, and the basin sediments having densities of $2.67 \mathrm{~g} / \mathrm{cm}^{3}, 2.48 \mathrm{~g} / \mathrm{cm}^{3}$, and $2.2 \mathrm{~g} / \mathrm{cm}^{3}$, respectively. Our model was developed using depths to basement inferred by the deepest sub-horizontal reflectors seen on the seismic transect (Fig. 16). Along the seismic transect, our gravity model assumes that variations in the gravity field are largely an indication of changes in the depth to Franciscan basement. Although lateral variations in the sedimentary section likely contribute to small anomalies in the gravity field, the largest anomalies in the gravity field are likely due to variations in the depth of basement rocks. Thus, our simplified model is probably indicative of the relative variation in the depth of basement rocks along the East Bay Plain seismic profile.

Our gravity models suggests that Franciscan basement is about $900 \mathrm{~m}$ deep from the eastern shore of the SF Bay to about meter 1500 of the seismic profile, where it abruptly rises to about $525 \mathrm{~m}$ depth. From about meter 1500 to about meter 2200, basement rises along a series of steps to about $400 \mathrm{~m}$ depth. Along the remainder of the profile, basement varies in depth between about 200 and $400 \mathrm{~m}$, except at the northeastern end of the profile, where basement sharply rises to within $50 \mathrm{~m}$ of the surface. Generally, the combined seismic/gravity model suggests a large vertical change in depth of basement near the bay, a small basin near the center of the transect, and a sharp rise in basement at the northeast end of the profile (Fig. 15). Our gravity model (based on seismic reflection images) is also consistent with basement depths modeled by Ponce et al. (2003) along an adjacent transect (Fig. 16), suggesting that the seismically imaged variations in basement structure are accurate. 
Table 3. Principal facts of gravity stations along the SL seismic transect. Latitudes and longitudes are based on the North American Datum 1927 (NAD27). CBA, complete Bouguer anomaly; Elev., elevation; FAA, free-air anomaly; ISO, isostatic anomaly; OG, observed gravity; SBA, simple Bouguer anomaly; TC, terrain correction.

\begin{tabular}{|c|c|c|c|c|c|c|c|c|c|c|}
\hline $\begin{array}{c}\text { Station } \\
\text { Name }\end{array}$ & $\begin{array}{l}\text { Location } \\
\text { Lat ( } \\
\text { Degrees }\end{array}$ & $\begin{array}{c}\text { Location } \\
\text { Lon } \\
\text { Degrees }\end{array}$ & $\begin{array}{l}\text { Elev } \\
\text { Feet }\end{array}$ & $\begin{array}{c}\text { Observed } \\
\text { Gravity } \\
\text { mGal }\end{array}$ & $\begin{array}{l}\text { FAA } \\
\text { mGal }\end{array}$ & $\begin{array}{r}\mathrm{SBA} \\
\mathrm{mGal}\end{array}$ & $\begin{array}{c}\text { TC } \\
\text { Inner } \\
\text { mGal }\end{array}$ & $\begin{array}{c}\text { TC } \\
\text { Outer } \\
\text { mGal }\end{array}$ & $\begin{array}{l}\text { CBA } \\
\mathrm{mGal}\end{array}$ & $\begin{array}{r}\text { ISO } \\
\text { mGal }\end{array}$ \\
\hline 02SF3002 & 3741.08 & 1227.71 & 31.7 & 979954.48 & -7.01 & -8.09 & 0.28 & 1.08 & -7.02 & -7.88 \\
\hline 02SF3018 & 3741.10 & 1227.67 & 34.3 & 979954.69 & -6.59 & -7.76 & 0.18 & 0.98 & -6.78 & -7.61 \\
\hline 02SF3030 & $37 \quad 41.12$ & 1227.63 & 37.2 & 979954.58 & -6.45 & -7.72 & 0.18 & 0.99 & -6.75 & -7.55 \\
\hline 02SF3050 & $37 \quad 41.12$ & 1227.57 & 34.7 & 979954.99 & -6.28 & -7.46 & 0.18 & 1 & -6.48 & -7.24 \\
\hline 02SF3074 & $37 \quad 41.15$ & 1227.50 & 36.8 & 979955.19 & -5.92 & -7.18 & 0.18 & 1 & -6.19 & -6.91 \\
\hline 02SF3090 & 3741.16 & 1227.45 & 37.7 & 979955.35 & -5.69 & -6.98 & 0.3 & 1.12 & -5.87 & -6.56 \\
\hline 02SF3110 & 3741.16 & 1227.38 & 37.6 & 979955.66 & -5.39 & -6.68 & 0.3 & 1.13 & -5.56 & -6.21 \\
\hline 02SF3130 & 3741.16 & 1227.32 & 39.3 & 979955.89 & -5 & -6.34 & 0.3 & 1.13 & -5.22 & -5.83 \\
\hline 02SF3145 & 3741.16 & 1227.27 & 39.5 & 979956.17 & -4.7 & -6.05 & 0.3 & 1.13 & -4.93 & -5.51 \\
\hline 02SF4007 & $37 \quad 41.30$ & $122 \quad 7.40$ & 36.1 & 979956.5 & -4.9 & -6.13 & 0 & 0.84 & -5.3 & -5.93 \\
\hline 02SF4020 & $37 \quad 41.33$ & 1227.37 & 37.2 & 979956.7 & -4.64 & -5.91 & 0 & 0.85 & -5.07 & -5.68 \\
\hline 02SF4040 & 3741.36 & 1227.32 & 34.8 & 979957.28 & -4.33 & -5.51 & 0 & 0.86 & -4.66 & -5.23 \\
\hline 02SF4053 & $37 \quad 41.39$ & 1227.28 & 34.4 & 979957.56 & -4.13 & -5.3 & 0 & 0.87 & -4.44 & -4.98 \\
\hline 02SF4B01 & $37 \quad 41.45$ & 1227.23 & 33.6 & 979958.1 & -3.75 & -4.9 & 0 & 0.89 & -4.02 & -4.51 \\
\hline 02SF4B02 & $37 \quad 41.48$ & $122 \quad 7.18$ & 32.3 & 979958.53 & -3.49 & -4.59 & 0 & 0.9 & -3.7 & -4.15 \\
\hline 02SF4B03 & $37 \quad 41.55$ & 1227.18 & 29.8 & 979958.9 & -3.46 & -4.47 & 0 & 0.92 & -3.56 & -4 \\
\hline 02SF4B04 & 3741.60 & 1227.09 & 32.9 & 979959.25 & -2.89 & -4.01 & 0 & 0.94 & -3.08 & -3.45 \\
\hline 02SF5001 & $37 \quad 41.63$ & 1227.06 & 34.6 & 979959.28 & -2.74 & -3.92 & 0 & 0.94 & -2.99 & -3.34 \\
\hline 02SF5020 & 3741.66 & 1227.01 & 37.8 & 979959.33 & -2.43 & -3.72 & 0 & 0.95 & -2.78 & -3.09 \\
\hline 02SF5040 & $37 \quad 41.70$ & 1226.96 & 37.6 & 979959.63 & -2.21 & -3.49 & 0 & 0.97 & -2.54 & -2.81 \\
\hline 02SF5058 & $37 \quad 41.73$ & $122 \quad 6.92$ & 36.1 & 979959.98 & -2.04 & -3.28 & 0 & 0.98 & -2.31 & -2.54 \\
\hline $02 \mathrm{SF} 6001$ & $\begin{array}{ll}37 & 41.77 \\
\end{array}$ & 1226.86 & 35.8 & 979959.86 & -2.25 & -3.47 & 0 & 1 & -2.49 & -2.68 \\
\hline 02SF6019 & \begin{tabular}{ll|}
37 & 41.81 \\
\end{tabular} & $122 \quad 6.81$ & 34.8 & 979960.37 & -1.89 & -3.08 & 0 & 1.02 & -2.07 & -2.21 \\
\hline 02SF6040 & $37 \quad 41.85$ & 1226.77 & 35.5 & 979960.49 & -1.77 & -2.98 & 0 & 1.04 & -1.95 & -2.06 \\
\hline 02SF6061 & $37 \quad 41.89$ & $122 \quad 6.72$ & 36.3 & 979960.49 & -1.75 & -2.99 & 0.01 & 1.07 & -1.93 & -1.99 \\
\hline 02SF6080 & $37 \quad 41.93$ & 1226.67 & 37.4 & 979960.52 & -1.67 & -2.95 & 0.03 & 1.12 & -1.84 & -1.86 \\
\hline 02SF6100 & $37 \quad 41.97$ & 1226.62 & 39.7 & 979960.5 & -1.54 & -2.89 & 0.07 & 1.18 & -1.72 & -1.7 \\
\hline 02SF6119 & 3742.00 & $122 \quad 6.58$ & 62.8 & 979959.27 & -0.64 & -2.78 & 0.07 & 1.15 & -1.66 & -1.61 \\
\hline 02SF6120 & $37 \quad 42.00$ & $122 \quad 6.58$ & 62.4 & 979959.19 & -0.75 & -2.88 & 0.07 & 1.15 & -1.76 & -1.71 \\
\hline 02SF6GPS & 3742.02 & $122 \quad 6.54$ & 77 & 979958.63 & 0.03 & -2.6 & 0.11 & 1.17 & -1.46 & -1.38 \\
\hline
\end{tabular}

\section{Interpretation and Discussion}

We interpret structures and stratigraphic relations along the SL seismic profiles on the basis of the combined reflection, refraction, well log, and gravity data. Many of these separate geophysical observations are consistent, leading to similar interpretations. Below, we discuss some of the more important issues related to earthquake hazards and ground-water-flow systems.

\section{Structure of the San Leandro Basin and East Bay Plain}

Consolidated basement rocks bound the aquifer system beneath the East Bay Plain. We interpret basement rocks to be the largely non-reflective rocks below depths of 200 to $1000 \mathrm{~m}$ along the seismic transect (Figs. 10 and 17; Fig 18). These rocks are probably Franciscan and older rocks that are not well stratified, and thus do not generate strong reflective energy. The poorly reflective probable Franciscan basement rocks are located below 800 to $1000 \mathrm{~m}$ depth southwest of meter 1300 of profile SL-1. At about meter 1300 of profile SL-1, basement rocks are vertically offset, east side up, several hundred meters along a zone of faults (Figs. 17 and 18). From about meter 1300 to about meter 2000, basement rocks rise along a series of faults to depths of about $400 \mathrm{~m}$ below land surface. The gravity anomaly along the southwestern $1300 \mathrm{~m}$ of profile SL-1 can be interpreted similarly, whereby basement abruptly rises by hundreds of meters over relatively short distances (Fig. 18). As observed within many strike-slip fault zones, there is greater vertical offset on some faults than other faults within a fault zone. From meter 2000 to about meter 3100 , basement varies only slightly in depth $(\sim 50 \mathrm{~m})$, but from about meter 3100 to about meter 4000, basement deepens by about $100 \mathrm{~m}$. Although the 
reflectors are not as well imaged along this segment of the transect as areas to the west, vertically offset reflectors suggest that basement deepens along one or more faults. Between meters 4000 and 4700 basement abruptly rises about 100-200 m to a depth of about $400 \mathrm{~m}$. This also probably occurs along one or more faults. Between meter 5000 and to about meter 6000 , basement rises to about $250 \mathrm{~m}$ depth, but because of large gaps in the seismic transect, we do not know if additional faults are present in this part of the transect. From about meter 6200 to the end of the seismic profile, basement abruptly rises to the near-surface along strands of the Hayward fault.

On the basis of the gravity and reflectivity patterns observed, we conclude that the deepest onshore part of the San Leandro Basin is about 800 to $900 \mathrm{~m}$ below the ground surface (bgs), and it extends northeastward about $1.4 \mathrm{~km}$ inland. Maximum depths of approximately $800 \mathrm{~m}$ for sub-horizontally layered sediments within the San Leandro Basin are consistent with observations by Marlow et al. (1999), who also imaged subhorizontal reflectors to depths of about $800 \mathrm{~m}$ near the center of the San Leandro Basin beneath the San Francisco Bay. However, on the basis of gravity modeling, Marlow et al. (1999) noted that relatively low-density $\left(2.12\right.$ to $\left.2.25 \mathrm{~g} / \mathrm{cm}^{3}\right)$ rocks may extend to as much as $1.5 \mathrm{~km}$ depth. Although we cannot rule out the possibility that additional sediments underlie the sub-horizontal strata within the San Leandro Basin, the reflectivity pattern below 800-900 m near the bay is consistent with shallow-depth basement rocks imaged farther northeast along the transect. Furthermore, gravity modeling is consistent with shallow depths to basement on the northeast end of the profile and our imaged depth near the bay of $800-900 \mathrm{~m}$.

\section{Evidence for Faults Underlying the East Bay Plain}

In several of the above sections of this report, we have highlighted evidence that infers the existence of faults beneath the East Bay Plain. In this section, we discuss the cumulative evidence. The principal evidence for the existence of buried faults beneath the East Bay Plain are the high-resolution reflection images, which show several zones along the transect where reflectors are vertically offset (Figs. 11, 19, 20, 21). We cannot exclude the possibility that some of the vertically offset reflections are artifacts related to non-linearity of the seismic profiles, but the combined velocity, gravity, and reflection data strongly suggest that the vertically offset reflectors are buried faults. Only selected individual faults are shown on figures 18 and 22. Further study likely may reveal additional faults. For purposes of discussion, we refer to the zones of vertically offset reflections as fault zones.

Fault zones are known to cause P-wave velocity anomalies, whereby lower seismic velocities occur within the fault zones relative to adjacent areas (Aki and Lee, 1976; Mooney and Luetgert, 1982; Catchings et al., 2002). Within the depth ranges of our seismic velocity measurements, we observe similar velocity anomalies within each of the probable near-surface East Bay Plain fault zones. Along profile SL-1, there are distinct low-velocity zones centered near meters 250 and 2250, and these low-velocity zones correlate with zones of near-surface, vertically offset reflections (Figs. 11 and 19). Similar, but less prominent low-velocity zones are observed along and between various profiles across the East Bay Plain.

The velocity data further suggest that several of the areas with vertically offset reflectors are zones of faulting by virtue of a relationship between the relative depth of fully saturated sediments and seismic velocity. As discussed above, unconsolidated, water-saturated sediments have minimum P-wave velocities of $1500 \mathrm{~m} / \mathrm{s}$ (Nur, 1982; Schon, 1996), and lateral variations in the $1500 \mathrm{~m} / \mathrm{s}$ velocity contours can be used to infer the relative depth of these sediments (Catchings et al.,1999; 2000a; Gandhok et al., 
1999). Along the East Bay Plain seismic transect, the depth to the $1500 \mathrm{~m} / \mathrm{s}$ velocity contour (saturated sediments) increases within and southwest of the major near-surface fault zones (as inferred by vertically offset reflectors) (Fig. 19). Conversely, the saturated sediments are most shallow northeast of the near-surface fault zones. Ground-water flows from the northeast to the southwest across the East Bay Plain (San Francisco Bay Regional Water Quality Control Board, 2004). Thus, the inferred lateral variation in relative depth to the ground-water table, whereby it is shallower to the northeast and deepens to the southwest of fault zones, is expected if the offset reflectors are groundwater barriers caused by faulting (Fig. 19). Mechanical disruption of sediments in fault zones reduces seismic velocity in a manner consistent with the seismic velocity profiles. Available ground-water-level data are areally too sparse and temporally too widely spread to definitively confirm or refute interpretations of water table depth derived from the seismic velocity data.

Gravity modeling is consistent with the seismic reflection image, whereby the gravity model infers near-vertical offsets in stratigraphic layers, especially near the northern end of the San Leandro Basin. These near-vertical offsets in stratigraphy suggest a number of fault strands underlie the East Bay Plain between the San Francisco Bay and the Hayward fault. Additional seismic profiling and paleoseismic trenching are needed to confirm the imaged fault zones, but the cumulative reflection, velocity, and gravity data presented in this study strongly suggest multiple fault strands underlie the East Bay Plain.

\section{Length of Faults}

Although the cumulative data suggest multiple fault strands underlie the East Bay Plain, the lengths of these faults are unknown. Fault length is important for earthquake hazard assessment because fault length is directly related to the maximum magnitude earthquake the faults can generate. Sparsely spaced earthquake hypocenters recorded between 1984 and 2004 (ANSS, 2004; Zoback and Olson, 1995; Simpson et al., 2004) are consistent with sub-alluvial faults that may extend from the southern Santa Clara Valley to the northern part of the San Francisco Bay. On the basis of vertically offset reflectors observed along the East Bay Plain seismic transect, we suggest that the fault zone bounding the San Leandro Basin on the northeast at about meter 1300 of the SL-1 profile may be the most laterally extensive of the East Bay Plain faults, with the exception of the Hayward fault. The lack of significant southwestward dipping strata within and near the northeastern end of the San Leandro Basin suggests that the northeastern end of the basin formed along a zone of faults with a significant $(\sim 500 \mathrm{~m})$ component of vertical movement rather than a uniformly down-warping central basin as suggested by Marlow et al. (1999). Such a large vertical offset suggests that the fault may be laterally extensive, and a growing body of geophysical evidence (Catchings et al., in prep.) suggests that the bounding fault may be an extension of the Silver Creek Fault zone. The Silver Creek fault zone has been mapped and imaged farther south within the Santa Clara Valley (Bortugno et al., 1991; Catchings et al., 2000b; R. Williams, Pers. Comm, 2005), and older ground-water and gravity data suggest that the fault extends as far north as Union City (CDWR, 1967). For purposes of discussion in the report, we refer to the fault bounding the San Leandro Basin as the East Bay fault zone, which would be more than $60 \mathrm{~km}$ long if it is contiguous with the Silver Creek fault zone. 


\section{Recency and Extent of Faulting Across the East Bay Plain}

If active, the East Bay fault zone may be capable of generating earthquakes with magnitudes comparable to or larger than those of the Hayward fault, based on comparison of the lengths of the faults. The shallow depths to which the East Bay fault zone offsets strata along profile SL-1 suggests that the fault has been active relatively recently (Figs. 11, 20, and 21). Furthermore, low-level seismicity in the vicinity of the imaged faults (Zoback and Olson, 1995; Simpson et al., 2004) indicates that the faults are probably active (Fig. 22). At shallow depths (upper $400 \mathrm{~m}$ ), vertically offset strata along the seismic transect indicate that other faults underlie the East Bay Plain between the East Bay and Hayward faults; we refer to these faults as middle faults. Although the middle faults may be separate faults, they may also be strands that merge with either the East Bay or Hayward fault zones at depth. Earthquake hypocenters indicate that some of the faults are deep seated (Simpson et al., 2004) and are unrelated to the Hayward fault above Moho depths.

\section{Aquifers}

Izbicki et al. (2003) list four principal zones in the East Bay Plain ground-water basin that may be time correlative with aquifer sediments in the Niles Cone ground-water basin, the Newark (9-40 m bgs), Centerville (36 to 67m bgs), Fremont (73 to $122 \mathrm{~m}$ bgs), and the Deep aquifers (152 to $198 \mathrm{~m}$ bgs). From comparisons among the seismic images and borehole electric and lithologic logs acquired near the seismic transect, the Deep aquifer correlates well with specific reflectors, but the Newark, Fremont, and Centerville aquifers do not stand out prominently on some electric logs, making their exact depth range poorly determined (Fig. 13). As such, there is some ambiguity in correlating the reflection horizons on the seismic image with specific layers of the Newark, Centerville, and Fremont aquifers. Many investigators have been unable to trace individual permeable beds of the Newark, Centerville, and Fremont aquifers between boreholes and wells in the East Bay Plain (Izbicki et al., 2003). In this report, we do not specifically identify the Newark, Centerville and Fremont aquifers; rather, we identify a series of reflectors that encompasses the depth ranges believed to include discontinuous permeable lenses of sediment that are time-correlative with the Newark, and the Centerville/Fremont aquifers as defined in the Niles Cone ground-water basin to the south. Partly consolidated sedimentary deposits having low porosity and low permeability are believed to underlie the major aquifers in the study area (Marlow et al., 1999), but we have not attempted to identify individual stratigraphic layers or permeable beds within the sediments underlying the Deep aquifer.

Near-coincident logged wells and the seismic transect show that aquifer zones often correlate with specific groups of reflectors. Some of these reflectors can be traced across the entire seismic transect, suggesting that the stratigraphic horizons that often contain permeable deposits are continuous across the East Bay Plain. The correlation between well logs and the reflection profile is best for the Deep aquifer, the thickest and most persistent permeable horizon of permeable sediments in the East Bay Plain (Figs. 13 and 21). A group of reflectors that correlate with the Deep aquifer varies in thickness across the East Bay Plain but is thickest near the SF Bay. Short-normal resistivity logs show that some layers of the Deep aquifer are consistently resistive, suggesting that they consist of clean, fresh-water-bearing sand and gravel layers. To the northeast, near San Leandro High School, there may be fewer coarse-grained layers within the Deep aquifer sediments. 
The hydraulic properties and quality of water within sediments that are strong reflectors beneath the Deep aquifer, seen most prominently southwest from meter 1300 of profile SL-1 and along profile SL-6, have not been determined. Historical well records indicate that several wells southwest from meter 1300 of profile SL-1 were drilled deeper than the bottom Deep aquifer in the early 1900s but well records do not identify perforated intervals of casing or water production rates for these deep wells. A downwell television scan (Michael Burke, Fugro West, written communication, 1997) of well 3S3W-14K2, drilled 993 feet deep in 1919, indicated that the steel well casing was perforated at depths below the Deep aquifer but other historical information is unavailable. Because well 14K2 is filled with sediment to 813 feet below land surface and much of the steel casing is encrusted with scale, the identification of perforated intervals by TV scan or hydraulic testing to determine hydraulic characteristics of sediments underlying the Deep aquifer are infeasible. If the reflectors beneath the Deep aquifer are Pliocene sediments (as Marlow and others (1999) suggest underlie Pleistocene deposits in the San Leandro basin) or if the reflectors are partly consolidated rocks (as encountered by deep wells near Bay Farm Island, north from the study area (Izbicki and others, 2003)), it is unlikely that the reflectors are aquifer zones that might be developed for water supply or artificial storage of water.

\section{East Bay Plain Faults, Ground-Water Flow, and Infrastructure}

In this report, we note several important features of the subsurface structure and stratigraphy that may impact ground-water flow and infrastructure across the East Bay Plain.

Hydraulic head data (Izbicki et al., 2003) indicate that ground water generally flows through shallow sediments from the hills on the east to the bay on the west. If the faults imaged on the reflection profile trend parallel to the Hayward fault, as expected, they may retard the flow of ground water toward the bay to some extent. Available ground-water-level data are areally too sparse to definitively confirm or refute interpretations of water table depth derived from the seismic velocity data.

Sedimentary units containing the Newark, Centerville/Fremont, and Deep aquifers are probably all affected by the fault zones, as their thickness and depth below ground surface appear to vary across the fault zones. If the faults hydraulically restrict westerly ground-water flow, they may partly compartmentalize the aquifer system, causing the performance of ground-water facilities to vary from operations as designed. A better understanding of the 3-dimensional aquifer structure and hydraulic continuity is needed to assess the effect of faults within the East Bay Plain.

Movement on faults underlying the East Bay Plain may restrict lateral groundwater flow. During future earthquakes, vertical movements of just a few meters may offset aquifers enough to affect flow across the fault zones. Similarly, such movements may hamper water-utility infrastructure such as pipelines. A more complete understanding of the locations and orientations of active faults within the East Bay Plain may allow for improvements before future damaging earthquakes. Such planning was implemented along the Alaska oil pipeline where it crossed four major fault zones identified from scientific investigations conducted in the 1970's. During the November 3, 2002 M. 7.9 Denali earthquake (Eberhart-Phillips et al., 2003), nearly $4 \mathrm{~m}$ of horizontal and $0.75 \mathrm{~m}$ of vertical offset occurred across the fault, but because of special engineering along the fault zones, there was no disruptive damage to the pipeline (Cluff and Slemmons, 2002). Similar engineering could be implemented across the East Bay Plain faults if their locations throughout the East Bay were determined. 


\section{Suggestions for Future Work}

Movement on fault zones beneath the East Bay Plain could affect ground-water-flow directions. A concerted effort to locate active faults beneath the East Bay Plain should be undertaken so that production wells can be strategically placed to minimize disruptions from future earthquakes on the subsurface faults. A combination of strategically placed water-level observation wells, high-resolution seismic imaging, INSAR imaging, and paleoseismological trenching may be a useful approach.

\section{Acknowledgements:}

We thank the East Bay Municipal Utility District (EBMUD) for providing partial funding for this investigation and assisting with access. We also thank Alameda County, the City of San Leandro, San Leandro High School, and EBMUD for permits and access. We thank Coyn Criley, Coye Criley, Dave Cornwell, Shane Detweiler, Joel Fassbinder, Sam Gudino, Wendy Hauso, Amy Padovani, A.S.S.S.R.S. Prashad, Friedericke Schmitz, Camgna Thach, and V Shridher for field assistance. Thanks to Jim Lienkamper and Jack Boatwright, who provided critical reviews. We thank Bob Bainer of Lawrence

Livermore National Laboratory for providing seismic sources along $163^{\text {rd }}$ Avenue in San Leandro, and we thank IRIS-PASSCAL for providing one of the multichannel seismographs used to record the data. We thank Kelly McPherson and Tim Dawson, USGS, for surveying the locations of shot points and sensor arrays.

\section{References}

2003 U.S. Census; http:/quickfacts.census.gov/qfd/states/06/06085.html

Aki, K., and W. H. K. Lee, 1976, Determination of three-dimensional velocity anomalies under a seismic array using P-arrival times from location earthquakes, I. A homogeneous initial model, J. Geophys. Res., 81, 4381-4399.

Advanced National Seismic System (ANSS) Catalog, 2004, anss@quake.geo.berkeley.edu

Atwater, B. G., Ross, B. E., Wehmiller, J.F., 1981, Stratigraphy of the late Quaternary estuarine deposits and amino acid stereochemistry of oyster shells beneath San Francisco Bay, California: Quaternary Research, v. 16, p. 181-200.

Aydin, A., 1982, The East Bay hills, a compressional domain resulting from interaction between the Calaveras and Hayward-Rogers Creek faults in E. W. Hart et al. (Eds), Proceedings, Conference on Earthquake Hazards in the Eastern San Francisco Bay Area: California Division of Mines and Geology Special Publication 62, p.11-21.

Bortugno, E.J., McJunkin, R.D., and Wagner, D.L., 1991, Map showing recency of faulting, San Francisco-San Jose quadrangle, 1:250,000: Department of Conservation, Division of Mines and Geology Regional Geologic Map Series, Map 5A, Sheet 5.

Brouwer, J., and Helbig, K., 1998, Shallow high-resolution reflection seismics. In: Helbig, K., Treitel, S. (Eds.), Handbook of Geophysical Exploration: Seismic Exploration, Vol. 19, Elsevier, New York, New York, 391 p.

California Department of Water Resources (CDWR), 1967, Evaluation of Ground Water Resources, South Bay, Appendix A: Geology: Bulletin 118-1, 153 p.

California Department of Water Resources (CDWR ), 1975, Evaluation of groundwater resources, south San Francisco Bay, Volume III, northern Santa Clara County area: Bulletin No. 118-1, various pagination 
California Department of Water Resources, Bulletin, 118-180, 1980, Ground water basins in California, $73 \mathrm{p}$.

Catchings, R.D., G. Gandhok, M. R. Goldman, E. Horta, M. J. Rymer, P. Martin, and A. Christensen, 1999, Subsurface, high-resolution seismic images from Cherry Valley, San Bernardino County, California: implications for water resources and earthquake hazards, U.S. Geol. Surv. Open-File Rept. 99-26, 57 pp.

Catchings, R.D., B.F. Cox, M. R. Goldman, G. Gandhok, M. J. Rymer, J. Dingler, P. Martin, A. Christensen, and E. Horta, 2000a, Subsurface structure and seismic velocities as determined from high-resolution seismic imaging in the Victorville, California area: implications for water resources and earthquake hazards, U.S. Geol. Surv. Open-File Rept., 00-123, 70 pp.

Catchings, R.D., M. R. Goldman, G. Gandhok, M. J. Rymer, and D. H. Underwood, 2000b, Seismic imaging evidence for faulting across the northwestern projection of the Silver Creek fault, San Jose, California, U. S. Geol. Surv. Open-File Rept., 00-125, 29 p.

Catchings, R. D., M. J. Rymer, M. R. Goldman, J. A. Hole, R. Huggins, and C. Lippus, 2002, High-resolution seismic velocities and shallow structure of the San Andreas fault zone at Middle Mountain, Parkfield, California, Bull. Seis. Soc. Am, 92, 2493-2503

Carmichael, R. S., 1989, Practical Handbook of Physical Properties of Rocks and Minerals, CRC Press, Boca Raton, Ann Arbor, Boston.

Ch2M-Hill, Inc., 2000, Regional hydrogeologic investigation of the south East Bay Plain, Oakland, California.

Cluff, L. S., and D. B. Slemmons, 2002, Trans Alaska pipeline design accommodations November 3, 2002 Magnitude 7.9 earthquake, EOS Trans. AGU, 83, S72F-1329

Dobrin, M. B., and C. H. Savit, 1988, Introduction to geophysical prospecting, McGraw-Hill Book Co., San Francisco, California, 867 pp.

Figuers, S., 1998, Groundwater study and water supply history of the East Bay Plain, Alameda and Contra Costa counties, California: Livermore, California, Norfleet Consultants, 90 p.

Eberhart-Phillips, D. and 28 others, 2003, The 2002 Denali Fault earthquake, Alaska: A large magnitude, slip-partitioned event, Science, 300, 111301118.

Gandhok, G., R. D. Catchings, M. R. Goldman, E. Horta, M. J. Rymer, P. Martin, and A.

Christensen, 1999, High-Resolution Seismic Reflection/Refraction Imaging from Interstate 10 to Cherry Valley Boulevard, Cherry Valley, Riverside County, California: Implications for Water Resources and Earthquake Hazards, U.S. Geological Survey Open-File Report 99-320, 52 pp., http://geopubs.wr.usgs.gov/open-file/of99-320/

Graymer, R.W., 2000, Geologic map and map data base $\mathrm{f}$ the Oakland metropolitan area, Alameda, Contra Costa, and San Francisco counties, California: U. S. Geological Survey, Misc. Field. Studies Map MF-2342, 1 sheet, scale 1:50,0000, http://geopubs.wr.usgs.gov/map-mf/mf2342/

Hole, J. A., 1992, Nonlinear high-resolution three-dimensional seismic traveltime tomography, Journal of Geophysical Research, v. 97, p. 6553-6562.

Howard, A. D., 1979, Geologic history of middle California: California Natural History Guides: 43, $113 \mathrm{p}$.

Izbicki, J.A, Borchers, J.W., Leighton, D.A., Kulongoski, J., Fields, L., Galloway, D.L., and Michel, R.L., 2003, Hydrogeology and geochemistry of aquifers underlying the San Lorenzo and San Leandro areas of the East Bay Plain, Alameda County, California, U.S. Geol. Surv. Water Resources Investigations Report 02-4259, http://pubs.usgs.gov/wri/wrir024259/text.html

Koltermann, C. E., and Gorelick, S. M., 1992, Paleoclimatic signature in terrestrial flood plain deposits: Science, v. 256, p. 1775-1782. 
Luhdorff and Scalmanini Consulting Engineers, 2003, East Bay Plain aquifer test project: South East Bay Plain and Niles Cone ground-water basins, 39 p.

Maslonkowski, Dennis (1988). Hydrogeology of the San Leandro and San Lorenzo Alluvial Cones of the Bay Plain Groundwater Basin, Alameda County, California, Masters of Science Thesis, San Jose State University, 143 p.

Marlow, M.S., R.C. Jachens, P.E. Hart, P.R. Carlson, R.J. Anima, J.R. Childs, 1999, Development of the San Leandro synform and neotectonics of the San Francisco Bay block, California, Marine and Petroleum Geology, v. 16, p. 431-442.

Mooney, W.D., and J. H. Luetgert, 1982, A seismic refraction study of the Santa Clara Valley and southern Santa Cruz Mountains, west-central California, Bull. Seism. Soc. Am., 72, 901-909

Mooney, W.D., and A. Ginzburg, 1986, Seismic measurements of the internal properties of fault zones, Pure and Applied Geophysics, 124, p. 141-157

Muir, K. S., 1993, Classification of groundwater recharge potential in the East Bay Plain area, Alameda County, California: Alameda County Flood Control and Water Conservation District, Hayward, Calif., C-92-320, 10 p.

Nur, A. (1982). Notes on wave propagation in porous rocks, Stanford Rock Physics Progress Report, January 1982, v. 13, 121 pp. Stanford University, Stanford, CA,

Ponce, D.A., 2001, Principal facts for gravity data along the Hayward fault and vicinity, San Francisco Bay area, northern California, U.S. Geological Survey Open-File Report 01-124, 29 pp., http://geopubs.wr.usgs.gov/open-file/of01-124/

Ponce, D.A., T. G. Hilderbrand, and R. C. Jachens, 2003, Gravity and magnetic expression of the San Leandro Gabbro with implications for the geometry and evolution of the Hayward Fault zone, Northern California, Bull. Seism. Soc. Am., 93, 14-26

Ross, B. E., 1977, The Pleistocene history of the San Francisco Bay along the southern crossing: Master of Science thesis, San Jose State University, $121 \mathrm{p}$.

Rogers, J. D., and Figuers, S.H., 1991, Engineering geologic site characterization of the greater Oakland-Alameda area, Alameda and San Francisco counties, California: Pleasant Hill, Calif., Rogers/Pacific, Inc., 59 p.

San Francisco Bay Regional Water Quality Control Board, 2004, East bay plain ground water basin beneficial use evaluation report, Final report.

Schon, J. H., 1996, Physical Properties of Rocks: Fundamentals and Principals of Petrophysics, Handbook of Geophysical Exploration, Seismic Exploration v. 18, Elsevier Science, Inc., Tarrytown, N. Y.

Simpson, R.W., R. W. Graymer, R.C. Jachens, D.A. Ponce, C.M. Wentworth, 2004, Crosssections and maps showing double-difference relocated earthquakes from 1984-2000 along the Hayward and Calaveras faults, California, U.S. Open-File Report 2004-1083a ( http://pubs.usgs.gov/of/2004/1083/explanation.html\#datasourceseqs ).

Sloan, D., 1992, The Yerba Buena mud: Record of the last-interglacial predecessor of San Francisco Bay, California: Geological Society of America, v.104, p. 716-727.

Stanley, R.G., Jachens, R.C., Lillis, P.G., McLaughlin, R.J., Kvenvolden, K.A., Hostettler, F.D., McDougall, K.A., and Magoon, L.B., 2002, Subsurface and Petroleum Geology of the Southwestern Santa Clara Valley (“Silicon Valley”), California: U.S. Geological Survey Professional Paper 1663, 55 p., http://geopubs.wr.usgs.gov/prof-paper/pp1663/

Trask, P. D., and Rolston, J. W., 1951, Engineering geology of San Francisco Bay, California: Bulletin of the Geological Society of America, v. 82, p. 1079-1110.

Unruh, J. R. and Lettis, W. R.,1998, Kinematics of transpressional deformation in the eastern San Francisco Bay region, California. Geology, v. 26, p.19-22. 
Waldhauser, F., and W. L. Ellsworth, 2000, A double-difference earthquake location algorithm: Method and application to the northern Hayward Fault, California, Bull. Seism. Soc. Am., 90, 1353-1368.

Waldhauser, F., and W. L. Ellsworth, 2002, Fault structure and mechanics of the Hayward Fault, California from double-difference earthquake locations, J. Geophys. Res., 107, 3-15.

Wallace, R. E., 1990, General features in the San Andreas fault system, California, in The San Andreas Fault System, California, R. E. Wallace, ed., U.S. Geol. Surv. Prof. Paper 1515, p. 3-12., http://pubs.usgs.gov/pp/1990/1515/

Zoback, M. L., Olson, J. A., and Jachens, R. C., 1995, Seismicity and basement structure beneath south San Francisco Bay, California in Sangines, E. M., Andersen, D. W., and Buising, A. V., eds., Recent geologic studies in the San Francisco Bay area: Pacific section of the Society of Economic Paleontologists and Mineralogists, Book 76, 278 p. 


\section{Figures}

Figure 1. Map of the San Francisco Bay area, with major fault zones and cities of the East Bay Plain and Niles Cone areas. The location of figure 2 and the general location of the seismic transect discussed in the report are shown by the red box. Various cities within the East Bay Plain are listed: $\mathrm{A}=$ Alameda, $\mathrm{F}=$ Fremont, $\mathrm{H}=$ Hayward, $\mathrm{N}=$ Newark, $\mathrm{O}=$ Oakland, $\mathrm{SL}=\mathrm{San}$ Lorenzo, $\mathrm{SLe}=\mathrm{San}$ Leandro, $\mathrm{UC}=$ Union City. Major roads are shown in gray, and major fault zones are shown in yellow.

Figure 2. Parts of the USGS 7.5-minute San Leandro and Hayward topographic maps showing the locations of the East Bay Plain (SL) seismic transect. Individual segments of the transect are labeled SL-1 through SL-6. The dashed line shows the general placement of the seismic arrays.

Figure 3. (a) Geophone elevation along seismic profile SL-1. Elevation is relative to the topographically lowest geophone along the profile. (b) Variation of geophones from a line that connects the first and last geophone along the profile. (c) Shot point elevation along seismic profile SL-1. Elevation is relative to the topographically lowest shot point along the profile. (d) Variation of shot points from a line connecting the first and last shot point along the profile. (e) Fold as a function of distance along the SL-1 seismic profile.

Figure 4. (a) Geophone elevation along seismic profile SL-2. Elevation is relative to the topographically lowest shot point along the profile. (b) Variation of geophones from a line that connects the first and last geophone along the profile. (c) Shot point elevation along seismic profile SL-2. Elevation is relative to the topographically lowest shot point along the profile. (d) Variation of geophones from a line connecting the first and last shot point along the profile. (e) Fold as a function of distance along the SL-2 seismic profile.

Figure 5. (a) Geophone elevation along seismic profile SL-3. Elevation is relative to the topographically lowest shot point along the profile. (b) Variation of geophones from a line that connects the first and last geophone along the profile. (c) Shot point elevation along seismic profile SL-3. Elevation is relative to the topographically lowest shot point along the profile. (d)Variation of geophones from a line connecting the first and last shot point along the profile. (e) Fold as a function of distance along the SL-3 seismic profile. 
Figure 6. (a) Geophone elevation along seismic profile SL-4. Elevation is relative to the topographically lowest shot point along the profile. (b) Variation of geophones from a line that connects the first and last geophone along the profile. (c) Shot point elevation along seismic profile SL-4. Elevation is relative to the topographically lowest shot point along the profile. (d) Variation of geophones from a line connecting the first and last shot point along the profile. (e) Fold as a function of distance along the SL-4 seismic profile.

Figure 7. (a) Geophone elevation along seismic profile SL-5. Elevation is relative to the topographically lowest shot point along the profile. (b) Variation of geophones from a line that connects the first and last geophone along the profile. (c) Shot point elevation along seismic profile SL-5. Elevation is relative to the topographically lowest shot point along the profile. (d) Variation of geophones from a line connecting the first and last shot point along the profile. (e) Fold as a function of distance along the SL-5 seismic profile.

Figure 8. (a) Geophone elevation along seismic profile SL-6. Elevation is relative to the topographically lowest shot point along the profile. (b) Variation of geophones from a line that connects the first and last geophone along the profile. (c) Shot point elevation along seismic profile SL-6. Elevation is relative to the topographically lowest shot point along the profile. (d) Variation of geophones from a line connecting the first and last shot point along the profile. (e) Fold as a function of distance along the SL-6 seismic profile.

Figure 9. P-wave seismic velocity model along the East Bay Plain seismic (SL) transect with various landmarks shown. Cumulative distance is shown along the bottom. Note that in profile view, profiles SL-3 and SL-4 overlap (see fig. 2), but lateral distance between the beginning and end of SL-3 and SL-4, respectively, is several hundred meters. Distance along individual profiles (see figure 2) are shown above the figure. Velocities are in $\mathrm{m} / \mathrm{s}$, and depth and distance are in meters. Depth is relative to the topographically lowest geophone along each seismic profile. The $1500 \mathrm{~m} / \mathrm{s}$ contour, which probably shows lateral variations in the relative depth to continuously saturated sediments (water depths), is shown in white. Because of smoothing in the velocity model, absolute depths of the water table may not be accurate.

Figure 10. A relatively low-frequency (30-60-200-400 Hz) composite seismic reflection image of the upper $1500 \mathrm{~m}$ along the East Bay Plain seismic transect. Stacking fold, elevation, and various landmarks are shown above the figure. Each seismic profile, SL-1 through SL-6, is shown relative to its distance from the southeastern-most geophone along the profile. However, distance between profiles SL-3 and SL4 includes lateral distance between the ends of the profiles. Depth and distance are in meters. Depth is relative to the lowest point along each seismic profile. 
Figure 11. A relatively high-frequency (50-100-200-400 Hz) composite seismic reflection image along the East Bay Plain, plotted as in figure 10. Only the upper $500 \mathrm{~m}$ are shown along the profile because the higher frequencies generally limit the depth of reflection imaging. The locations of various wells with available geophysical and lithologic logs and various landmarks are shown above the figure.

Figure 12. Photograph of the area encompassing the East Bay Plain seismic transect and selected nearby wells. Seismic profiles are shown in red, and perpendicular projections of the wells to the seismic profile are shown in yellow. The base map is modified from the USGS San Leandro and Hayward, California 7.5-minute orthophoto maps.

Figure 13. Seismic image from figure 11 with short-normal resistivity logs (red) and simplified lithologic logs (multi-colored) projected onto the seismic image at perpendicular distances. Sedimentary layers that contain aquifers in some places are shown in blue. Lateral extensions of the aquifer-bearing layers are inferred based on laterally continuous or nearly continuous reflectors. Continuity of reflectors between the profiles is only inferred.

Figure 14. Topographic map of the central East Bay Plain, showing the general location of the East Bay Plain (SL) seismic transect, along which our gravity model is constructed (orange), and the profile along which the model (profile C-C"; in black) of Ponce et al., (2003) is constructed. The yellow dots show earthquake epicenters with size proportional to magnitude. The red line shows the approximate surface trace of the Hayward fault (from Ponce et al., 2003).

Figure 15. (a) Observed (blue) and calculated (red) Bouguer gravity anomaly along the East Bay Plain seismic transect. (b) Gravity model based on seismic-reflectiondetermined depths to basement rocks (green) and the best fit to the Bouguer gravity data. Density (in parentheses) is in grams per cubic centimeter. Because distance between profiles SL-3 and SL-4 is mostly lateral distance, basement depths are extrapolated in that area. 
Figure 16. Observed (black) and calculated (red) (a) magnetic and (b) gravity anomaly

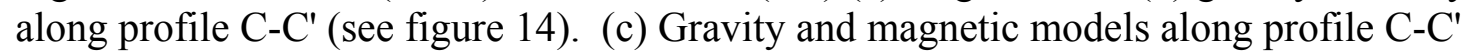
(from Ponce et al., 2003). Geologic symbols: Qa, Quaternary alluvium and related lowdensity materials; Tn, Neroly Sandstone; Ts, undifferentiated Tertiary sedimentary rocks; KJF, Franciscan Complex; Kjm, Joaquin Miller Fm; Kjk, Knoxville Fm; Ko, Oakland conglomerate; Ks, undifferentiated Cretaceous sedimentary rocks; Jb, basalt; Jgb, gabbro; $\mathrm{Jpb}$, pillow basalt; jsv, quartz keratophyre; sp, serpentinite; sp-px, pyroxenite. Geographic and other symbols: SF Bay, San Francisco bay; SL Res., San Leandro reservoir, Inverted red triangles, recent trace of Hayward Fault (HF) and Chabot Fault (CF); D, density in grams/cubic centimeter; S, susceptibility in CGS units; Drill-hole symbol, thickness of offshore sedimentary basin from seismic and gravity data (Marlow et al., 1999); +, seismicity from relocated hypocenters using double-difference relocation method within $5 \mathrm{~km}$ of the profile (Waldhauser and Ellsworth, 2000; 2002). The red rectangle shows the approximate location of the East Bay Plain seismic transect $(2 \mathrm{~km}$ depth).

Figure 17. (a) Composite seismic image (30-60-200-400 Hz) from figure 10 with interpreted layer sequences (blue) containing ground-water aquifers, electric and lithologic well logs, faults (red), and basement topography, as modeled with our SL gravity model (yellow) and the model of Ponce et al. (2003) (orange) north of the SL seismic profile. The basement topography modeled by Ponce et al. (2003) is extrapolated (dashed line) along segments of the SL profile that do not trend northwestward.

Figure 17 (b) Seismic reflection image along profile SL-1, plotted with lower frequencies $(25-50-400-800 \mathrm{~Hz})$ than in figure 17a. Gravity-inferred basement topography (orange Ponce et al., 2003; yellow $=$ SL gravity model) is superimposed on the reflection image.

Figure 18. Interpretative cross section (including wells, electric logs, sedimentary sequences containing aquifers, faults, etc), with basement as inferred from the SL gravity model (black-green). Basement as inferred from the model of Ponce et al. (2003) north of the SL profile is shown in orange. The basement topography modeled by Ponce et al. (2003) is extrapolated (dashed line) along segments of the SL profile that does not trend northwestward. Areas along the East Bay transect with apparent shallow-depth faults are outlined in red above the interpretative cross section.

Figure 19. (a) Velocity model (from figure 9) along the East Bay Plain seismic transect, with the $1500 \mathrm{~m} / \mathrm{s}$ velocity contour (lateral variation in the relative depth of continuously saturated sediments) shown in white (b) Relatively high-frequency (50-100-200-400 Hz) seismic reflection image (from figure 11) with borehole electric logs and interpretative sedimentary sequences that contain aquifers in places. Note that low-velocity zones correlate with apparent zones of near-surface (upper $80 \mathrm{~m}$ ) faulting. 
Figure 20. A relatively low-frequency $(25-50-400-800 \mathrm{~Hz})$ migrated seismic reflection image along profile SL-1. Note the numerous vertically offset layers, particularly those between meters 200 and 400 and meters 1600 and 2500. The red arrows are located over two zones of faulting that are most apparent at about $400 \mathrm{~m}$ depth.

Figure 21. A relatively intermediate-frequency $(35-70-200-400 \mathrm{~Hz})$ migrated seismic reflection image of all profiles along the East Bay Plain seismic transect. Borehole resistivity and lithologic well logs and interpreted sedimentary sequences that sometimes contain aquifers are shown on the seismic section. The pink line in the upper $50 \mathrm{~m}$ shows the $1500 \mathrm{~m} / \mathrm{s}$ velocity contour along the seismic transect (interpolated between seismic profiles) as determined from the SL velocity model (fig. 9).

Figure 22. Seismic reflection image (from figure 17b) along profile SL-1 with hypocenters of earthquakes within $3 \mathrm{~km}$ of the profile. Earthquake locations are from the Northern California Catalog (ANSS, 2004). Note that the hypocenters from nearby small earthquakes largely align with the northeastern edge of the San Leandro Basin. Earthquakes beyond $3 \mathrm{~km}$ from the SL profile are shown in figure 14. 


\section{Appendixes}

\section{Appendix A.}

Coordinates of the beginning and end of each profile in latitude and longitude and in UTM coordinates

\begin{tabular}{|c|c|c|c|c|}
\hline LINE & LAT & LONG & Easting & Northing \\
\hline Start SL1 & $37: 40.1174$ & $-122: 09.8860$ & 573661 & 4169377 \\
\hline End SL1 & $37: 41.0649$ & $-122: 08.3701$ & 575873 & 4171150 \\
\hline Start SL2 & & & & 4171212 \\
\hline End SL2 & $37: 41.0984$ & $-122: 08.3085$ & 575963 & 4171170 \\
\hline & & $-122: 07.8083$ & 576698 & \\
\hline Start SL3 & $37: 41.0727$ & $-122: 07.7788$ & 576742 & 4171172 \\
\hline End SL3 & $37: 41.1566$ & $-122: 07.3337$ & 577394 & 4171333 \\
\hline Start SL4 & $37: 41.2864$ & $-122: 07.4765$ & 577182 & 4171571 \\
\hline End SL4 & $37: 41.3865$ & $-122: 07.3429$ & 577377 & 4171758 \\
\hline Start SL5 & $37: 41.6257$ & $-122: 07.1288$ & & 4172203 \\
\hline End SL5 & $37: 41.7245$ & $-122: 06.9805$ & 577903 & 4172388 \\
\hline Start SL6 & $37: 41.7864$ & $-122: 06.9004$ & & \\
\hline End SL6 & $37: 42.0097$ & $-122: 06.6289$ & 578020 & 4172504 \\
\hline
\end{tabular}

\section{Appendix B}

Distances and elevations along East Bay Seismic Profile 1 (SL-1).

Measurements are relative to the first receiver point at the west end of Profile SL-1.

\begin{tabular}{|c|c|c|c|c|c|}
\hline Station No. & Receiver Dist. (m) & $\begin{array}{l}\text { Receiver Elev. } \\
\text { (m) }\end{array}$ & Station No. & Shot Dist. (m) & Shot Elev. (m) \\
\hline 1 & 0 & 0 & & & \\
\hline 2 & 3.4 & 0.04 & & & \\
\hline 3 & 7.36 & 0.06 & & & \\
\hline 4 & 10.81 & 0.13 & & & \\
\hline 5 & 14.71 & 0.13 & & & \\
\hline 6 & 19.56 & 0.17 & & & \\
\hline 7 & 24.46 & 0.17 & & & \\
\hline 8 & 29.21 & 0.31 & & & \\
\hline 9 & 34.16 & 0.53 & 9 & 34.06 & 0.46 \\
\hline 10 & 39.01 & 0.59 & 10 & 38.76 & 0.59 \\
\hline 11 & 43.96 & 0.57 & 11 & 43.81 & 0.59 \\
\hline 12 & 48.87 & 0.63 & 12 & 48.66 & 0.62 \\
\hline 13 & 53.77 & 0.74 & 13 & 53.47 & 0.74 \\
\hline 14 & 58.62 & 0.74 & 14 & 58.37 & 0.73 \\
\hline 15 & 63.52 & 0.67 & 15 & 63.22 & 0.68 \\
\hline 16 & 68.37 & 0.74 & 16 & 68.17 & 0.77 \\
\hline 17 & 73.52 & 0.78 & 17 & 73.22 & 0.82 \\
\hline 18 & 78.27 & 0.81 & 18 & 78.02 & 0.82 \\
\hline 19 & 83.02 & 0.82 & 19 & 82.92 & 0.84 \\
\hline 20 & 88.07 & 0.81 & 20 & 87.87 & 0.87 \\
\hline 21 & 92.87 & 0.86 & 21 & 92.62 & 0.9 \\
\hline 22 & 97.72 & 0.87 & 22 & 97.47 & 0.91 \\
\hline 23 & 102.67 & 0.9 & 23 & 102.42 & 0.9 \\
\hline 24 & 107.67 & 0.89 & 24 & 107.38 & 0.88 \\
\hline 25 & 112.53 & 0.9 & 25 & 112.22 & 0.86 \\
\hline 26 & 117.37 & 0.89 & 26 & 117.08 & 0.86 \\
\hline 27 & 122.28 & 0.9 & 27 & 121.87 & 0.9 \\
\hline 28 & 127.18 & 0.96 & 28 & 126.92 & 0.99 \\
\hline 29 & 132.12 & 0.97 & 29 & 131.83 & 0.96 \\
\hline 30 & 136.88 & 1.01 & 30 & 136.78 & 1.02 \\
\hline 31 & 141.78 & 1.02 & 31 & 141.58 & 1 \\
\hline 32 & 146.63 & 0.99 & 32 & 146.53 & 1.01 \\
\hline
\end{tabular}




\begin{tabular}{|c|c|c|c|c|c|}
\hline 33 & 151.58 & 0.95 & 33 & 151.33 & 0.97 \\
\hline 34 & 156.43 & 0.95 & 34 & 156.28 & 0.97 \\
\hline 35 & 161.33 & 0.97 & 35 & 161.03 & 1 \\
\hline 36 & 166.18 & 0.9 & 36 & 165.93 & 0.95 \\
\hline 37 & 171.03 & 0.95 & 37 & 170.93 & 0.95 \\
\hline 38 & 175.98 & 0.95 & 38 & 175.68 & 1 \\
\hline 39 & 180.88 & 0.96 & 39 & 180.58 & 0.97 \\
\hline 40 & 185.69 & 0.98 & 40 & 185.54 & 1.05 \\
\hline 41 & 190.58 & 1.03 & 41 & 190.39 & 1.08 \\
\hline 42 & 195.43 & 1.01 & 42 & 195.18 & 1.05 \\
\hline 43 & 200.33 & 1.02 & 43 & 200.29 & 1.03 \\
\hline 44 & 205.18 & 1.05 & & & \\
\hline 45 & 210.09 & 1.09 & 45 & 209.93 & 1.06 \\
\hline 46 & 215.08 & 1.09 & 46 & 214.99 & 1.04 \\
\hline 47 & 220.04 & 1.16 & 47 & 220.04 & 1.13 \\
\hline 48 & 224.99 & 1.2 & 48 & 224.94 & 1.18 \\
\hline 49 & 229.94 & 1.28 & 49 & 230.04 & 1.25 \\
\hline 50 & 234.99 & 1.25 & 50 & 235.14 & 1.29 \\
\hline 51 & 239.99 & 1.13 & 51 & 239.94 & 1.19 \\
\hline 52 & 244.94 & 1.06 & 52 & 244.84 & 1.17 \\
\hline 53 & 249.99 & 1.12 & 53 & 249.93 & 1.18 \\
\hline 54 & 254.94 & 1.09 & 54 & 254.84 & 1.21 \\
\hline 55 & 259.99 & 1.09 & 55 & 260.14 & 1.17 \\
\hline 56 & 264.89 & 1.11 & 56 & 264.89 & 1.11 \\
\hline 57 & 269.98 & 1.22 & 57 & 269.79 & 1.17 \\
\hline 58 & 274.83 & 1.24 & 58 & 274.94 & 1.18 \\
\hline 59 & 279.98 & 1.18 & 59 & 279.83 & 1.15 \\
\hline 60 & 284.89 & 1.13 & 60 & 285.03 & 1.07 \\
\hline 61 & 289.99 & 1.21 & 61 & 289.88 & 1.19 \\
\hline 62 & 294.88 & 1.2 & 62 & 294.79 & 1.22 \\
\hline 63 & 299.99 & 1.16 & 63 & 299.64 & 1.26 \\
\hline 64 & 305.14 & 1.26 & 64 & 304.84 & 1.33 \\
\hline 65 & 309.89 & 1.18 & 65 & 309.84 & 1.16 \\
\hline 66 & 314.84 & 1.29 & 66 & 314.89 & 1.29 \\
\hline 67 & 319.89 & 1.23 & 67 & 319.98 & 1.31 \\
\hline 68 & 324.93 & 1.25 & 68 & 324.89 & 1.29 \\
\hline 69 & 329.94 & 1.37 & 69 & 330.13 & 1.36 \\
\hline 70 & 334.48 & 1.34 & & & \\
\hline 71 & 339.84 & 1.31 & 71 & 339.83 & 1.41 \\
\hline 72 & 344.84 & 1.29 & 72 & 344.89 & 1.29 \\
\hline 73 & 349.84 & 1.32 & & & \\
\hline 74 & 354.84 & 1.27 & 74 & 354.79 & 1.3 \\
\hline 75 & 359.84 & 1.37 & 75 & 359.79 & 1.35 \\
\hline 76 & 364.78 & 1.34 & 76 & 364.98 & 1.31 \\
\hline 77 & 369.78 & 1.32 & & & \\
\hline 78 & 374.78 & 1.35 & 78 & 374.89 & 1.3 \\
\hline 79 & 379.84 & 1.3 & 79 & 379.89 & 1.35 \\
\hline 80 & 384.84 & 1.3 & 80 & 384.83 & 1.36 \\
\hline 81 & 389.94 & 1.4 & 81 & 389.68 & 1.33 \\
\hline 82 & 394.89 & 1.4 & 82 & 394.89 & 1.29 \\
\hline 83 & 399.89 & 1.36 & 83 & 400.08 & 1.32 \\
\hline 84 & 404.84 & 1.43 & 84 & 404.99 & 1.31 \\
\hline 85 & 409.84 & 1.43 & 85 & 409.83 & 1.4 \\
\hline 86 & 414.78 & 1.46 & 86 & 414.83 & 1.4 \\
\hline 87 & 419.89 & 1.41 & & & \\
\hline 88 & 424.84 & 1.56 & 88 & 424.89 & 1.53 \\
\hline 89 & 429.78 & 1.51 & 89 & 429.89 & 1.51 \\
\hline 90 & 434.89 & 1.51 & 90 & 434.89 & 1.45 \\
\hline 91 & 440.03 & 1.48 & & & \\
\hline 92 & 444.74 & 1.37 & 92 & 444.89 & 1.36 \\
\hline 93 & 449.93 & 1.35 & 93 & 449.83 & 1.34 \\
\hline 94 & 454.93 & 1.4 & & & \\
\hline 95 & 459.64 & 1.33 & 95 & 459.64 & 1.35 \\
\hline 96 & 464.59 & 1.32 & 96 & 464.84 & 1.38 \\
\hline 97 & 469.84 & 1.35 & 97 & 469.73 & 1.35 \\
\hline 98 & 474.84 & 1.29 & 98 & 474.73 & 1.44 \\
\hline 99 & 479.74 & 1.35 & 99 & 479.84 & 1.44 \\
\hline 100 & 484.89 & 1.32 & 100 & 484.64 & 1.37 \\
\hline 101 & 489.89 & 1.41 & 101 & 489.58 & 1.49 \\
\hline 102 & 494.89 & 1.44 & 102 & 494.73 & 1.47 \\
\hline
\end{tabular}




\begin{tabular}{|c|c|c|c|c|c|}
\hline 103 & 499.83 & 1.35 & 103 & 499.94 & 1.37 \\
\hline 104 & 504.79 & 1.43 & & & \\
\hline 105 & 509.79 & 1.38 & 105 & 509.84 & 1.41 \\
\hline 106 & 514.68 & 1.34 & 106 & 514.64 & 1.32 \\
\hline 107 & 519.83 & 1.35 & 107 & 519.73 & 1.36 \\
\hline 108 & 524.78 & 1.39 & 108 & 524.83 & 1.38 \\
\hline 109 & 529.78 & 1.4 & & & \\
\hline 110 & 534.74 & 1.43 & 110 & 534.74 & 1.38 \\
\hline 111 & 539.84 & 1.35 & 111 & 539.69 & 1.36 \\
\hline 112 & 544.84 & 1.38 & 112 & 544.69 & 1.35 \\
\hline 113 & 549.79 & 1.45 & 113 & 549.69 & 1.39 \\
\hline 114 & 554.73 & 1.48 & 114 & 554.69 & 1.43 \\
\hline 115 & 559.88 & 1.6 & 115 & 559.74 & 1.51 \\
\hline 116 & 564.58 & 1.5 & 116 & 564.74 & 1.49 \\
\hline 117 & 569.88 & 1.5 & 117 & 569.69 & 1.46 \\
\hline 118 & 574.84 & 1.6 & 118 & 574.84 & 1.56 \\
\hline 119 & 579.79 & 1.59 & & & \\
\hline 120 & 584.88 & 1.64 & 120 & 584.84 & 1.55 \\
\hline 121 & 589.88 & 1.63 & 121 & 589.69 & 1.6 \\
\hline 122 & 594.53 & 1.66 & 122 & 594.64 & 1.67 \\
\hline 123 & 599.83 & 1.7 & 123 & 599.74 & 1.69 \\
\hline 124 & 604.69 & 1.73 & 124 & 604.79 & 1.71 \\
\hline 125 & 609.74 & 1.66 & 125 & 609.69 & 1.6 \\
\hline 126 & 614.84 & 1.69 & 126 & 614.64 & 1.74 \\
\hline 127 & 619.79 & 1.72 & 127 & 619.74 & 1.67 \\
\hline 128 & 624.79 & 1.7 & & & \\
\hline 129 & 629.83 & 1.82 & 129 & 629.64 & 1.71 \\
\hline 130 & 634.83 & 1.61 & 130 & 634.74 & 1.36 \\
\hline 131 & 639.83 & 1.65 & 131 & 639.79 & 1.54 \\
\hline 132 & 644.88 & 1.57 & 132 & 644.89 & 1.43 \\
\hline 133 & 649.88 & 1.43 & 133 & 649.94 & 1.38 \\
\hline 134 & 654.83 & 1.52 & 134 & 654.79 & 1.42 \\
\hline 135 & 659.79 & 1.56 & 135 & 659.79 & 1.52 \\
\hline 136 & 664.84 & 1.72 & 136 & 664.79 & 1.8 \\
\hline 137 & 669.74 & 1.77 & 137 & 669.68 & 1.82 \\
\hline 138 & 674.79 & 1.66 & 138 & 674.79 & 1.71 \\
\hline 139 & 679.94 & 1.69 & 139 & 679.79 & 1.7 \\
\hline 140 & 684.94 & 1.69 & 140 & 684.74 & 1.69 \\
\hline 141 & 689.89 & 1.72 & 141 & 689.79 & 1.73 \\
\hline 142 & 694.89 & 1.69 & & & \\
\hline 143 & 699.94 & 1.51 & 143 & 699.89 & 1.64 \\
\hline 144 & 704.92 & 1.48 & & & \\
\hline 145 & 709.89 & 1.44 & 145 & 709.79 & 1.47 \\
\hline 146 & 714.84 & 1.68 & 146 & 714.74 & 1.76 \\
\hline 147 & 719.69 & 1.69 & 147 & 719.79 & 1.75 \\
\hline 148 & 724.74 & 1.77 & 148 & 724.79 & 1.77 \\
\hline 149 & 729.78 & 1.71 & 149 & 729.83 & 1.76 \\
\hline 150 & 734.78 & 1.83 & & & \\
\hline 151 & 739.71 & 1.9 & 151 & 739.68 & 1.94 \\
\hline 152 & 744.66 & 1.91 & 152 & 744.64 & 1.94 \\
\hline 153 & 749.74 & 1.93 & 153 & 749.73 & 1.96 \\
\hline 154 & 754.64 & 1.96 & 154 & 754.64 & 1.98 \\
\hline 155 & 759.68 & 1.96 & 155 & 759.68 & 1.98 \\
\hline 156 & 764.67 & 1.93 & 156 & 764.68 & 1.95 \\
\hline 157 & 769.77 & 1.9 & 157 & 769.79 & 1.91 \\
\hline 158 & 775.16 & 1.9 & 158 & 775.19 & 1.91 \\
\hline 159 & 779.6 & 2.04 & 159 & 779.64 & 2.04 \\
\hline 160 & 784.68 & 1.88 & 160 & 784.73 & 1.88 \\
\hline 161 & 789.64 & 1.89 & 161 & 789.69 & 1.89 \\
\hline 162 & 794.78 & 1.86 & & & \\
\hline 163 & 799.78 & 1.85 & 163 & 799.84 & 1.86 \\
\hline 164 & 804.73 & 1.89 & 164 & 804.79 & 1.9 \\
\hline 165 & 809.58 & 1.92 & 165 & 809.64 & 1.93 \\
\hline 166 & 814.77 & 1.9 & 166 & 814.84 & 1.92 \\
\hline 167 & 819.62 & 1.94 & 167 & 819.69 & 1.96 \\
\hline 168 & 824.62 & 2.01 & 168 & 824.69 & 2.03 \\
\hline 169 & 829.5 & 2.08 & 169 & 829.58 & 2.1 \\
\hline 170 & 834.61 & 2 & 170 & 834.69 & 2.02 \\
\hline 171 & 839.65 & 1.92 & 171 & 839.73 & 1.95 \\
\hline 172 & 844.6 & 1.95 & 172 & 844.69 & 1.98 \\
\hline
\end{tabular}




\begin{tabular}{|c|c|c|c|c|c|}
\hline 173 & 849.64 & 1.97 & 173 & 849.73 & 2 \\
\hline 174 & 854.45 & 1.94 & 174 & 854.54 & 1.97 \\
\hline 175 & 859.49 & 2 & 175 & 859.58 & 2.04 \\
\hline 176 & 864.43 & 2.11 & 176 & 864.53 & 2.15 \\
\hline 177 & 869.43 & 2.14 & 177 & 869.53 & 2.18 \\
\hline 178 & 874.49 & 2.03 & 178 & 874.59 & 2.08 \\
\hline 179 & 879.53 & 1.97 & 179 & 879.64 & 2.02 \\
\hline 180 & 884.53 & 2.01 & 180 & 884.64 & 2.06 \\
\hline 181 & 889.57 & 1.97 & 181 & 889.68 & 2.03 \\
\hline 182 & 894.43 & 2.05 & 182 & 894.54 & 2.11 \\
\hline 183 & 899.62 & 2 & 183 & 899.74 & 2.07 \\
\hline 184 & 904.57 & 2.08 & 184 & 904.69 & 2.15 \\
\hline 185 & 909.47 & 2.08 & 185 & 909.59 & 2.16 \\
\hline 186 & 914.42 & 2.06 & 186 & 914.54 & 2.15 \\
\hline 187 & 919.57 & 2.07 & 187 & 919.69 & 2.16 \\
\hline 188 & 924.46 & 2.11 & 188 & 924.59 & 2.21 \\
\hline 189 & 929.46 & 2.17 & 189 & 929.59 & 2.27 \\
\hline 190 & 934.46 & 2.14 & 190 & 934.59 & 2.25 \\
\hline 191 & 939.46 & 2.13 & 191 & 939.59 & 2.25 \\
\hline 192 & 944.46 & 2.07 & 192 & 944.59 & 2.19 \\
\hline 193 & 949.34 & 2.15 & 193 & 949.48 & 2.28 \\
\hline 194 & 954.49 & 2.19 & 194 & 954.63 & 2.32 \\
\hline 195 & 959.45 & 2.22 & 195 & 959.59 & 2.36 \\
\hline 196 & 964.2 & 2.28 & 196 & 964.34 & 2.43 \\
\hline 197 & 969.4 & 2.22 & 197 & 969.54 & 2.37 \\
\hline 198 & 974.14 & 2.11 & 198 & 974.29 & 2.27 \\
\hline 199 & 979.24 & 2.13 & 199 & 979.39 & 2.29 \\
\hline 200 & 984.49 & 2.23 & 200 & 984.64 & 2.4 \\
\hline 201 & 989.46 & 2.3 & 201 & 989.59 & 2.47 \\
\hline 202 & 994.57 & 2.23 & 202 & 994.69 & 2.39 \\
\hline 203 & 999.49 & 2.2 & 203 & 999.59 & 2.36 \\
\hline 204 & 1004.51 & 2.2 & 204 & 1004.59 & 2.36 \\
\hline 205 & 1009.38 & 2.27 & 205 & 1009.44 & 2.42 \\
\hline 206 & 1014.39 & 2.38 & 206 & 1014.44 & 2.53 \\
\hline 207 & 1019.35 & 2.4 & 207 & 1019.38 & 2.55 \\
\hline 208 & 1024.53 & 2.4 & 208 & 1024.54 & 2.54 \\
\hline 209 & 1029.54 & 2.34 & 209 & 1029.54 & 2.48 \\
\hline 210 & 1034.46 & 2.35 & 210 & 1034.44 & 2.48 \\
\hline 211 & 1039.27 & 2.26 & 211 & 1039.23 & 2.39 \\
\hline 212 & 1044.59 & 2.41 & 212 & 1044.54 & 2.54 \\
\hline 213 & 1049.61 & 2.53 & 213 & 1049.54 & 2.65 \\
\hline 214 & 1054.63 & 2.48 & 214 & 1054.54 & 2.6 \\
\hline 215 & 1059.59 & 2.54 & 215 & 1059.49 & 2.66 \\
\hline 216 & 1064.41 & 2.56 & 216 & 1064.29 & 2.67 \\
\hline 217 & 1069.73 & 2.59 & 217 & 1069.59 & 2.7 \\
\hline 218 & 1074.65 & 2.57 & 218 & 1074.49 & 2.68 \\
\hline 219 & 1079.71 & 2.66 & 219 & 1079.54 & 2.76 \\
\hline 220 & 1084.48 & 2.73 & 220 & 1084.29 & 2.83 \\
\hline 221 & 1089.68 & 2.76 & 221 & 1089.53 & 2.82 \\
\hline 222 & 1094.49 & 2.52 & 222 & 1094.38 & 2.53 \\
\hline 223 & 1099.56 & 2.57 & 223 & 1099.49 & 2.54 \\
\hline 224 & 1104.46 & 2.67 & 224 & 1104.44 & 2.6 \\
\hline 225 & 1109.57 & 2.72 & 225 & 1109.59 & 2.61 \\
\hline 226 & 1114.23 & 2.72 & 226 & 1114.29 & 2.56 \\
\hline 227 & 1119.29 & 2.83 & 227 & 1119.39 & 2.63 \\
\hline 228 & 1124.19 & 3.17 & 228 & 1124.34 & 2.91 \\
\hline 229 & 1129.14 & 3.32 & & & \\
\hline 230 & 1134.19 & 3.46 & & & \\
\hline 231 & 1139.04 & 3.07 & & & \\
\hline 232 & 1144.24 & 3.17 & & & \\
\hline 233 & 1149.19 & 3.07 & & & \\
\hline 234 & 1150.33 & 4.66 & 234 & 1150.38 & 4.67 \\
\hline 235 & 1155.38 & 4.88 & 235 & 1155.54 & 4.73 \\
\hline 236 & 1160.23 & 4.53 & 236 & 1160.49 & 4.67 \\
\hline 237 & 1165.18 & 4.25 & 237 & 1165.43 & 4.5 \\
\hline 238 & 1170.18 & 4.15 & 238 & 1170.29 & 4.23 \\
\hline 239 & 1175.13 & 4.05 & 239 & 1175.23 & 4.11 \\
\hline 240 & 1180.13 & 3.95 & 240 & 1180.18 & 4.05 \\
\hline 241 & 1185.03 & 3.9 & 241 & 1185.08 & 3.96 \\
\hline 242 & 1190.03 & 3.95 & 242 & 1190.08 & 4.01 \\
\hline
\end{tabular}




\begin{tabular}{|c|c|c|c|c|c|}
\hline 243 & 1195.12 & 3.96 & 243 & 1195.18 & 4.02 \\
\hline 244 & 1200.02 & 4.18 & 244 & 1200.08 & 4.24 \\
\hline 245 & 1204.96 & 4.4 & 245 & 1205.03 & 4.46 \\
\hline 246 & 1209.96 & 4.26 & 246 & 1210.03 & 4.33 \\
\hline 247 & 1214.7 & 4.07 & 247 & 1214.78 & 4.14 \\
\hline 248 & 1219.85 & 3.98 & 248 & 1219.93 & 4.05 \\
\hline 249 & 1224.59 & 4.04 & 249 & 1224.68 & 4.11 \\
\hline 250 & 1229.64 & 4.11 & 250 & 1229.73 & 4.18 \\
\hline 251 & 1234.68 & 4.1 & 251 & 1234.77 & 4.17 \\
\hline 252 & 1239.57 & 4.1 & 252 & 1239.67 & 4.17 \\
\hline 253 & 1244.47 & 4.08 & 253 & 1244.57 & 4.15 \\
\hline 254 & 1249.56 & 4.07 & 254 & 1249.67 & 4.14 \\
\hline 255 & 1254.46 & 4.11 & 255 & 1254.57 & 4.18 \\
\hline 256 & 1259.26 & 4.03 & 256 & 1259.38 & 4.11 \\
\hline 257 & 1264.41 & 3.94 & 257 & 1264.53 & 4.02 \\
\hline 258 & 1269.3 & 3.97 & 258 & 1269.43 & 4.05 \\
\hline 259 & 1274.19 & 3.96 & 259 & 1274.32 & 4.04 \\
\hline 260 & 1279.18 & 4.02 & 260 & 1279.32 & 4.1 \\
\hline 261 & 1284.13 & 3.95 & 261 & 1284.27 & 4.03 \\
\hline 262 & 1289.15 & 4.04 & 262 & 1289.28 & 4.13 \\
\hline 263 & 1293.89 & 4.05 & 263 & 1294.02 & 4.14 \\
\hline 264 & 1299 & 4.03 & 264 & 1299.12 & 4.13 \\
\hline 265 & 1303.85 & 3.99 & 265 & 1303.97 & 4.1 \\
\hline 266 & 1308.91 & 3.98 & 266 & 1309.02 & 4.09 \\
\hline 267 & 1313.81 & 4.04 & 267 & 1313.92 & 4.16 \\
\hline 268 & 1318.82 & 4.06 & 268 & 1318.92 & 4.19 \\
\hline 269 & 1323.81 & 3.89 & 269 & 1323.91 & 4.03 \\
\hline 270 & 1328.68 & 3.89 & 270 & 1328.77 & 4.03 \\
\hline 271 & 1333.74 & 3.85 & 271 & 1333.82 & 4 \\
\hline 272 & 1338.64 & 4.02 & 272 & 1338.72 & 4.18 \\
\hline 273 & 1343.65 & 3.98 & 273 & 1343.72 & 4.14 \\
\hline 274 & 1348.75 & 4.03 & 274 & 1348.82 & 4.2 \\
\hline 275 & 1353.51 & 4.04 & 275 & 1353.57 & 4.22 \\
\hline 276 & 1358.61 & 4.17 & 276 & 1358.67 & 4.35 \\
\hline 277 & 1363.36 & 4.08 & 277 & 1363.41 & 4.27 \\
\hline 278 & 1368.31 & 4.1 & 278 & 1368.36 & 4.29 \\
\hline 279 & 1373.26 & 4.12 & 279 & 1373.46 & 4.35 \\
\hline 280 & 1378.37 & 4.23 & 280 & 1378.42 & 4.4 \\
\hline 281 & 1383.31 & 4.23 & 281 & 1383.36 & 4.46 \\
\hline 282 & 1388.26 & 4.24 & 282 & 1388.51 & 4.42 \\
\hline 283 & 1392.97 & 4.29 & 283 & 1393.21 & 4.47 \\
\hline 284 & 1398.08 & 4.3 & 284 & 1398.31 & 4.49 \\
\hline 285 & 1403.09 & 4.38 & 285 & 1403.31 & 4.57 \\
\hline 286 & 1408.05 & 4.37 & 286 & 1408.26 & 4.56 \\
\hline 287 & 1412.96 & 4.33 & 287 & 1413.16 & 4.53 \\
\hline 288 & 1417.97 & 4.27 & 288 & 1418.16 & 4.47 \\
\hline 289 & 1422.78 & 4.3 & 289 & 1422.96 & 4.51 \\
\hline 290 & 1427.89 & 3.41 & 290 & 1428.06 & 3.62 \\
\hline 291 & 1432.75 & 4.39 & 291 & 1432.91 & 4.6 \\
\hline 292 & 1437.82 & 4.35 & 292 & 1437.96 & 4.57 \\
\hline 293 & 1442.73 & 4.35 & 293 & 1442.86 & 4.57 \\
\hline 294 & 1447.74 & 4.37 & 294 & 1447.86 & 4.59 \\
\hline 295 & 1452.6 & 4.3 & 295 & 1452.71 & 4.53 \\
\hline 296 & 1457.61 & 4.29 & 296 & 1457.71 & 4.52 \\
\hline 297 & 1462.67 & 4.31 & 297 & 1462.76 & 4.55 \\
\hline 298 & 1467.63 & 4.39 & 298 & 1467.71 & 4.63 \\
\hline 299 & 1472.54 & 4.44 & 299 & 1472.61 & 4.68 \\
\hline 300 & 1477.54 & 4.38 & 300 & 1477.6 & 4.63 \\
\hline 301 & 1482.6 & 4.51 & 301 & 1482.65 & 4.76 \\
\hline 302 & 1487.51 & 4.73 & 302 & 1487.61 & 4.84 \\
\hline 303 & 1492.41 & 5.12 & 303 & 1492.56 & 5.08 \\
\hline 304 & 1497.3 & 5.4 & 304 & 1497.5 & 5.22 \\
\hline 305 & 1502.2 & 5.07 & 305 & 1502.5 & 5.38 \\
\hline 306 & 1507.1 & 4.58 & 306 & 1507.4 & 4.89 \\
\hline 307 & 1511.91 & 4.65 & 307 & 1512.2 & 4.96 \\
\hline 308 & 1516.86 & 4.63 & 308 & 1517.15 & 4.94 \\
\hline 309 & 1521.92 & 4.69 & 309 & 1522.21 & 5 \\
\hline 310 & 1526.92 & 4.62 & 310 & 1527.2 & 4.93 \\
\hline 311 & 1531.92 & 4.63 & 311 & 1532.2 & 4.94 \\
\hline 312 & 1536.77 & 4.72 & 312 & 1537.05 & 5.03 \\
\hline
\end{tabular}




\begin{tabular}{|c|c|c|c|c|c|}
\hline 313 & 1541.82 & 4.57 & 313 & 1542.1 & 4.87 \\
\hline 314 & 1546.73 & 4.53 & 314 & 1547 & 4.83 \\
\hline 315 & 1551.68 & 4.59 & 315 & 1551.95 & 4.89 \\
\hline 316 & 1556.57 & 4.63 & 316 & 1556.84 & 4.93 \\
\hline 317 & 1561.68 & 4.59 & 317 & 1561.94 & 4.89 \\
\hline 318 & 1566.53 & 4.6 & 318 & 1566.79 & 4.9 \\
\hline 319 & 1571.54 & 4.61 & 319 & 1571.8 & 4.91 \\
\hline 320 & 1576.5 & 4.53 & 320 & 1576.75 & 4.83 \\
\hline 321 & 1581.4 & 4.57 & 321 & 1581.65 & 4.87 \\
\hline 322 & 1586.31 & 4.56 & 322 & 1586.55 & 4.86 \\
\hline 323 & 1591.27 & 4.59 & 323 & 1591.5 & 4.89 \\
\hline 324 & 1596.07 & 4.6 & 324 & 1596.29 & 4.9 \\
\hline 325 & 1601.14 & 4.61 & 325 & 1601.35 & 4.91 \\
\hline 326 & 1606.14 & 4.59 & 326 & 1606.34 & 4.89 \\
\hline 327 & 1610.95 & 4.59 & 327 & 1611.14 & 4.89 \\
\hline 328 & 1616.01 & 4.62 & 328 & 1616.19 & 4.92 \\
\hline 329 & 1620.98 & 4.67 & 329 & 1621.15 & 4.97 \\
\hline 330 & 1626.09 & 4.63 & 330 & 1626.25 & 4.93 \\
\hline 331 & 1630.89 & 4.58 & 331 & 1631.04 & 4.88 \\
\hline 332 & 1635.8 & 4.61 & 332 & 1635.94 & 4.91 \\
\hline 333 & 1640.86 & 4.59 & 333 & 1640.99 & 4.89 \\
\hline 334 & 1645.77 & 4.68 & 334 & 1645.89 & 4.98 \\
\hline 335 & 1650.87 & 4.66 & 335 & 1650.98 & 4.96 \\
\hline 336 & 1655.69 & 4.64 & 336 & 1655.79 & 4.94 \\
\hline 337 & 1660.7 & 4.73 & 337 & 1660.79 & 5.03 \\
\hline 338 & 1665.5 & 4.77 & 338 & 1665.58 & 5.07 \\
\hline 339 & 1670.52 & 4.76 & 339 & 1670.59 & 5.06 \\
\hline 340 & 1675.58 & 4.72 & 340 & 1675.64 & 5.02 \\
\hline 341 & 1680.49 & 4.72 & 341 & 1680.54 & 5.02 \\
\hline 342 & 1685.43 & 4.68 & 342 & 1685.49 & 4.98 \\
\hline 343 & 1690.4 & 4.74 & 343 & 1690.48 & 5.05 \\
\hline 344 & 1695.24 & 4.83 & 344 & 1695.33 & 5.14 \\
\hline 345 & 1700.08 & 4.67 & 345 & 1700.18 & 4.99 \\
\hline 346 & 1705.23 & 4.69 & 346 & 1705.34 & 5.01 \\
\hline 347 & 1710.01 & 4.72 & 347 & 1710.13 & 5.05 \\
\hline 348 & 1714.89 & 4.77 & 348 & 1715.03 & 5.1 \\
\hline 349 & 1719.93 & 4.69 & 349 & 1720.08 & 5.03 \\
\hline 350 & 1724.87 & 4.76 & 350 & 1725.03 & 5.1 \\
\hline 351 & 1730.01 & 4.77 & 351 & 1730.18 & 5.11 \\
\hline 352 & 1734.79 & 4.78 & 352 & 1734.98 & 5.13 \\
\hline 353 & 1739.63 & 4.56 & 353 & 1739.83 & 4.91 \\
\hline 354 & 1744.77 & 4.74 & 354 & 1744.98 & 5.1 \\
\hline 355 & 1749.7 & 4.72 & 355 & 1749.93 & 5.08 \\
\hline 356 & 1754.64 & 4.89 & 356 & 1754.88 & 5.26 \\
\hline 357 & 1759.43 & 4.86 & 357 & 1759.68 & 5.23 \\
\hline 358 & 1764.37 & 4.83 & 358 & 1764.63 & 5.21 \\
\hline 359 & 1769.3 & 4.93 & 359 & 1769.58 & 5.31 \\
\hline 360 & 1774.39 & 4.98 & 360 & 1774.68 & 5.37 \\
\hline 361 & 1779.33 & 5.03 & 361 & 1779.63 & 5.42 \\
\hline 362 & 1784.17 & 5.24 & 362 & 1784.48 & 5.63 \\
\hline 363 & 1789.2 & 5.35 & 363 & 1789.52 & 5.74 \\
\hline 364 & 1794.14 & 5.33 & & & \\
\hline 365 & 1799.09 & 5.24 & 365 & 1799.43 & 5.63 \\
\hline 366 & 1804.18 & 5.13 & 366 & 1804.53 & 5.52 \\
\hline 367 & 1808.96 & 5.1 & 367 & 1809.32 & 5.49 \\
\hline 368 & 1813.86 & 5.06 & 368 & 1814.23 & 5.45 \\
\hline 369 & 1818.84 & 5.07 & 369 & 1819.22 & 5.46 \\
\hline 370 & 1823.83 & 4.95 & 370 & 1824.22 & 5.34 \\
\hline 371 & 1828.77 & 4.99 & 371 & 1829.17 & 5.38 \\
\hline 372 & 1833.75 & 4.9 & 372 & 1834.17 & 5.3 \\
\hline 373 & 1838.49 & 4.96 & 373 & 1838.92 & 5.36 \\
\hline 374 & 1843.23 & 4.98 & 374 & 1843.67 & 5.38 \\
\hline 375 & 1848.22 & 4.99 & 375 & 1848.67 & 5.39 \\
\hline 376 & 1853.11 & 4.95 & 376 & 1853.57 & 5.35 \\
\hline 377 & 1858.1 & 4.96 & 377 & 1858.57 & 5.36 \\
\hline 378 & 1863.24 & 5.09 & 378 & 1863.72 & 5.49 \\
\hline 379 & 1868.13 & 5.09 & 379 & 1868.62 & 5.49 \\
\hline 380 & 1873.12 & 5.15 & 380 & 1873.62 & 5.55 \\
\hline 381 & 1878.06 & 5.14 & 381 & 1878.57 & 5.54 \\
\hline 382 & 1883.09 & 5.09 & 382 & 1883.57 & 5.49 \\
\hline
\end{tabular}




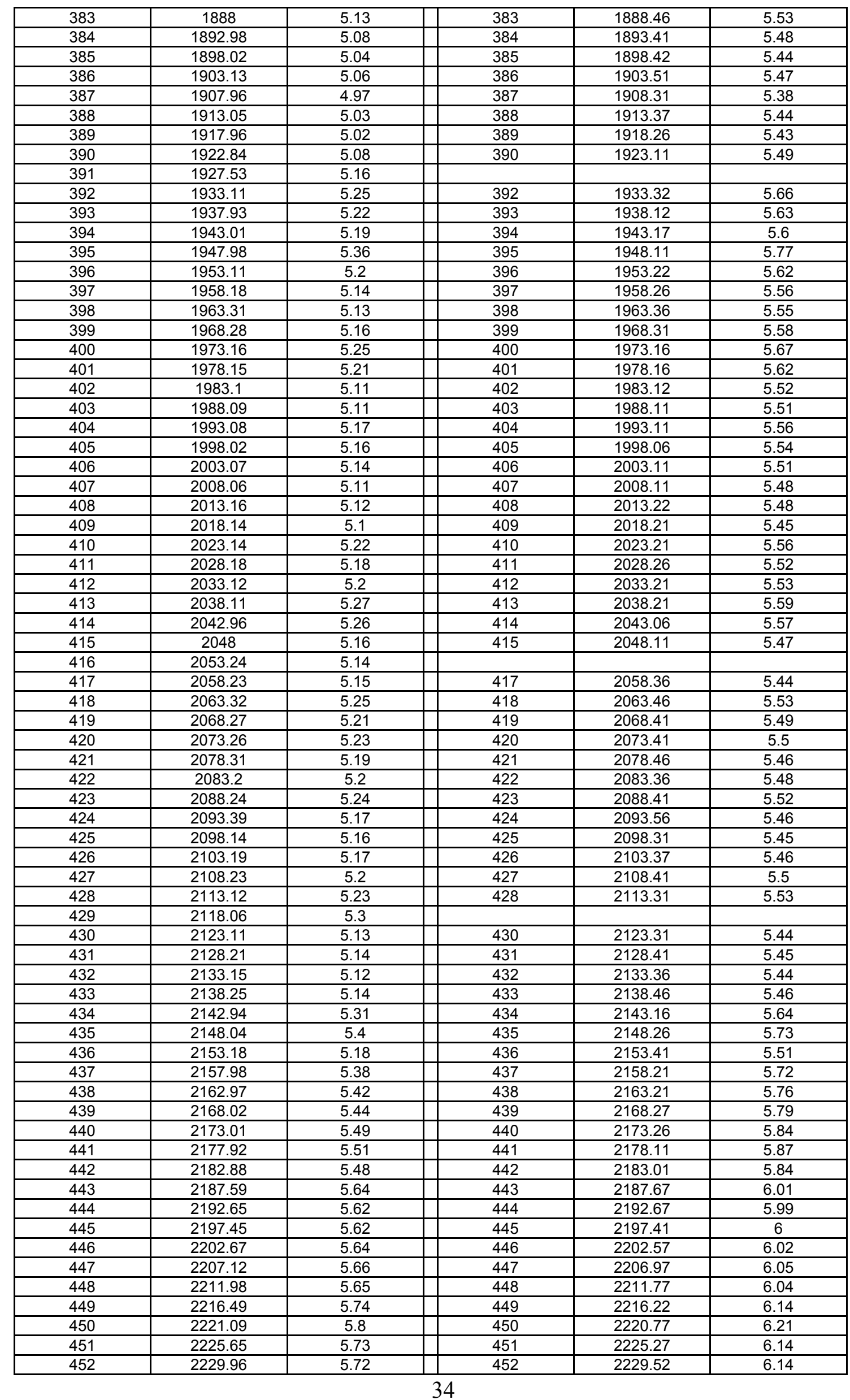




\begin{tabular}{|c|c|c|c|c|c|}
\hline 453 & 2234.77 & 5.72 & 453 & 2234.27 & 6.14 \\
\hline 454 & 2238.64 & 5.68 & 454 & 2238.08 & 6.11 \\
\hline 455 & 2242.74 & 5.61 & 455 & 2242.13 & 6.04 \\
\hline 456 & 2246.61 & 5.84 & 456 & 2245.94 & 6.28 \\
\hline 457 & 2250.57 & 5.55 & & & \\
\hline 458 & 2254.51 & 5.8 & 458 & 2253.73 & 6.25 \\
\hline 459 & 2258.18 & 5.81 & 459 & 2257.34 & 6.26 \\
\hline 460 & 2261.99 & 5.71 & 460 & 2261.09 & 6.17 \\
\hline 461 & 2266.07 & 5.57 & 461 & 2265.19 & 6.01 \\
\hline 462 & 2269.76 & 5.56 & 462 & 2268.9 & 5.98 \\
\hline 463 & 2273.35 & 5.5 & 463 & 2272.5 & 5.91 \\
\hline 464 & 2276.78 & 5.56 & 464 & 2275.95 & 5.95 \\
\hline 465 & 2280.56 & 5.35 & 465 & 2279.75 & 5.72 \\
\hline 466 & 2284 & 5.46 & 466 & 2283.21 & 5.81 \\
\hline 467 & 2287.74 & 5.25 & 467 & 2286.96 & 5.58 \\
\hline 468 & 2291.57 & 5.3 & 468 & 2290.81 & 5.62 \\
\hline 469 & 2295.36 & 5.37 & & & \\
\hline 470 & 2298.94 & 5.62 & 470 & 2298.21 & 5.9 \\
\hline 471 & 2302.83 & 5.63 & 471 & 2302.12 & 5.89 \\
\hline 472 & 2306.76 & 5.7 & 472 & 2306.07 & 5.94 \\
\hline 473 & 2310.84 & 5.7 & 473 & 2310.17 & 5.93 \\
\hline 474 & 2314.98 & 5.72 & & & \\
\hline 475 & 2319.26 & 5.79 & & & \\
\hline 476 & 2323.74 & 5.68 & 476 & 2323.12 & 5.85 \\
\hline 477 & 2328.13 & 5.79 & 477 & 2327.53 & 5.94 \\
\hline 478 & 2332.81 & 5.86 & 478 & 2332.23 & 6 \\
\hline 479 & 2337.3 & 5.89 & 479 & 2336.73 & 6.01 \\
\hline 480 & 2341.78 & 5.98 & 480 & 2341.23 & 6.08 \\
\hline 481 & 2346.61 & 5.95 & 481 & 2346.08 & 6.05 \\
\hline 482 & 2351.4 & 5.97 & 482 & 2350.89 & 6.06 \\
\hline 483 & 2356.12 & 5.99 & 483 & 2355.63 & 6.08 \\
\hline 484 & 2361.01 & 5.99 & 484 & 2360.54 & 6.08 \\
\hline 485 & 2366.23 & 6.04 & 485 & 2365.78 & 6.13 \\
\hline 486 & 2370.92 & 6.14 & 486 & 2370.49 & 6.23 \\
\hline 487 & 2376.09 & 6.28 & 487 & 2375.68 & 6.36 \\
\hline 488 & 2381.13 & 6.2 & 488 & 2380.74 & 6.28 \\
\hline 489 & 2386.16 & 6.29 & 489 & 2385.79 & 6.37 \\
\hline 490 & 2391.29 & 6.24 & 490 & 2390.94 & 6.31 \\
\hline 491 & 2396.03 & 6.26 & 491 & 2395.69 & 6.33 \\
\hline 492 & 2401.01 & 6.4 & 492 & 2400.69 & 6.47 \\
\hline 493 & 2405.94 & 6.49 & & & \\
\hline 494 & 2411.12 & 6.53 & & & \\
\hline 495 & 2415.95 & 6.55 & 495 & 2415.69 & 6.61 \\
\hline 496 & 2420.98 & 6.58 & & & \\
\hline 497 & 2425.81 & 6.58 & 497 & 2425.59 & 6.64 \\
\hline 498 & 2430.84 & 6.55 & 498 & 2430.64 & 6.6 \\
\hline 499 & 2435.97 & 6.54 & 499 & 2435.79 & 6.59 \\
\hline 500 & 2440.79 & 6.57 & 500 & 2440.63 & 6.62 \\
\hline 501 & 2445.78 & 6.61 & 501 & 2445.64 & 6.65 \\
\hline 502 & 2450.77 & 6.71 & 502 & 2450.64 & 6.75 \\
\hline 503 & 2455.65 & 6.66 & 503 & 2455.54 & 6.69 \\
\hline 504 & 2460.79 & 6.6 & 504 & 2460.69 & 6.63 \\
\hline 505 & 2465.77 & 6.5 & 505 & 2465.69 & 6.52 \\
\hline 506 & 2470.61 & 6.47 & & & \\
\hline 507 & 2475.74 & 6.39 & 507 & 2475.69 & 6.4 \\
\hline 508 & 2480.63 & 6.19 & 508 & 2480.59 & 6.19 \\
\hline 509 & 2485.61 & 6.06 & 509 & 2485.59 & 6.06 \\
\hline 510 & 2490.65 & 5.92 & 510 & 2490.64 & 5.91 \\
\hline 511 & 2495.58 & 5.82 & 511 & 2495.59 & 5.8 \\
\hline 512 & 2500.56 & 5.77 & 512 & 2500.59 & 5.75 \\
\hline 513 & 2505.5 & 5.8 & 513 & 2505.54 & 5.77 \\
\hline 514 & 2510.58 & 5.83 & & & \\
\hline 515 & 2515.62 & 5.9 & 515 & 2515.69 & 5.86 \\
\hline 516 & 2520.6 & 5.93 & 516 & 2520.69 & 5.88 \\
\hline 517 & 2525.49 & 5.91 & 517 & 2525.59 & 5.86 \\
\hline 518 & 2530.43 & 6.03 & 518 & 2530.55 & 5.97 \\
\hline 519 & 2535.46 & 6.04 & 519 & 2535.59 & 5.98 \\
\hline 520 & 2540.44 & 6.05 & 520 & 2540.59 & 5.98 \\
\hline 521 & 2545.21 & 6.06 & 521 & 2545.34 & 6 \\
\hline 522 & 2550.33 & 6.08 & 522 & 2550.44 & 6.03 \\
\hline
\end{tabular}




\begin{tabular}{|c|c|c|c|c|c|}
\hline 523 & 2555.27 & 6.06 & 523 & 2555.35 & 6.02 \\
\hline 524 & 2560.38 & 6.15 & 524 & 2560.44 & 6.12 \\
\hline 525 & 2565.45 & 6.39 & 525 & 2565.49 & 6.37 \\
\hline 526 & 2569.72 & 6.67 & 526 & 2569.74 & 6.66 \\
\hline 527 & 2574.55 & 6.94 & 527 & 2574.54 & 6.94 \\
\hline 528 & 2579.13 & 7.02 & 528 & 2579.1 & 7.03 \\
\hline 529 & 2584.05 & 7.06 & 529 & 2584 & 7.08 \\
\hline 530 & 2588.72 & 7.07 & 530 & 2588.65 & 7.1 \\
\hline 531 & 2593.65 & 7.08 & 531 & 2593.55 & 7.12 \\
\hline 532 & 2598.17 & 7.12 & 532 & 2598.05 & 7.17 \\
\hline 533 & 2602.89 & 7.1 & 533 & 2602.75 & 7.16 \\
\hline 534 & 2607.73 & 7.05 & 534 & 2607.56 & 7.12 \\
\hline 535 & 2612.29 & 7.14 & 535 & 2612.1 & 7.22 \\
\hline 536 & 2617.07 & 7.16 & 536 & 2616.86 & 7.25 \\
\hline 537 & 2621.69 & 7.14 & 537 & 2621.46 & 7.24 \\
\hline 538 & 2626.26 & 7.19 & 538 & 2626 & 7.3 \\
\hline 539 & 2630.54 & 7.05 & 539 & 2630.26 & 7.17 \\
\hline 540 & 2635.76 & 7.17 & 540 & 2635.46 & 7.3 \\
\hline 541 & 2640.3 & 7.14 & 541 & 2640.01 & 7.27 \\
\hline 542 & 2645.09 & 7.22 & & & \\
\hline 543 & 2649.77 & 7.16 & 543 & 2649.51 & 7.29 \\
\hline 544 & 2654.61 & 7.16 & 544 & 2654.36 & 7.29 \\
\hline 545 & 2659.15 & 7.22 & 545 & 2658.91 & 7.34 \\
\hline 546 & 2663.85 & 7.18 & 546 & 2663.62 & 7.3 \\
\hline 547 & 2668.68 & 7.22 & 547 & 2668.47 & 7.34 \\
\hline 548 & 2673.17 & 7.19 & 548 & 2672.97 & 7.31 \\
\hline 549 & 2677.96 & 7.22 & 549 & 2677.77 & 7.34 \\
\hline 550 & 2682.59 & 7.24 & 550 & 2682.42 & 7.36 \\
\hline 551 & 2687.18 & 7.24 & 551 & 2687.02 & 7.36 \\
\hline 552 & 2691.88 & 7.28 & 552 & 2691.73 & 7.4 \\
\hline 553 & 2696.67 & 7.29 & 553 & 2696.53 & 7.41 \\
\hline 554 & 2701.41 & 7.36 & 554 & 2701.28 & 7.48 \\
\hline 555 & 2705.99 & 7.38 & 555 & 2705.88 & 7.5 \\
\hline 556 & 2710.73 & 7.41 & 556 & 2710.63 & 7.52 \\
\hline 557 & 2715.52 & 7.44 & 557 & 2715.43 & 7.55 \\
\hline 558 & 2720.66 & 7.46 & 558 & 2720.58 & 7.57 \\
\hline 559 & 2725.39 & 7.47 & 559 & 2725.33 & 7.58 \\
\hline 560 & 2730.43 & 7.45 & 560 & 2730.38 & 7.56 \\
\hline 561 & 2735.41 & 7.47 & 561 & 2735.38 & 7.55 \\
\hline 562 & 2740.34 & 7.47 & 562 & 2740.33 & 7.51 \\
\hline 563 & 2745.43 & 7.47 & 563 & 2745.44 & 7.48 \\
\hline 564 & 2750.36 & 7.52 & 564 & 2750.38 & 7.5 \\
\hline 565 & 2755.29 & 7.56 & 565 & 2755.33 & 7.5 \\
\hline 566 & 2760.32 & 7.55 & 566 & 2760.38 & 7.46 \\
\hline 567 & 2765.25 & 7.45 & 567 & 2765.33 & 7.33 \\
\hline 568 & 2769.98 & 7.45 & 568 & 2770.08 & 7.29 \\
\hline 569 & 2774.91 & 7.44 & 569 & 2775.03 & 7.25 \\
\hline 570 & 2779.74 & 7.53 & 570 & 2779.87 & 7.31 \\
\hline 571 & 2784.63 & 7.58 & 571 & 2784.78 & 7.33 \\
\hline 572 & 2789.41 & 7.74 & 572 & 2789.58 & 7.45 \\
\hline 573 & 2794.19 & 7.81 & 573 & 2794.38 & 7.49 \\
\hline 574 & 2799.12 & 7.95 & 574 & 2799.33 & 7.6 \\
\hline 575 & 2803.94 & 7.98 & 575 & 2804.17 & 7.59 \\
\hline 576 & 2808.73 & 8.04 & 576 & 2808.97 & 7.62 \\
\hline 577 & 2813.61 & 8.16 & 577 & 2813.87 & 7.71 \\
\hline 578 & 2818.49 & 8 & & & \\
\hline 579 & 2823.32 & 7.64 & 579 & 2823.62 & 7.12 \\
\hline 580 & 2828.32 & 7.41 & 580 & 2828.42 & 7.07 \\
\hline 581 & 2833.17 & 7.66 & 581 & 2833.12 & 7.18 \\
\hline
\end{tabular}

\section{Appendix C}

Distances and elevations along East Bay Seismic Profile 2 (SL-2).

Measurements are relative to the first receiver point at the west end of Profile SL-2.

\begin{tabular}{|c|c|c|c|c|c|c|}
\hline Station No. & Receiver Dist. $(\mathrm{m})$ & $\begin{array}{c}\text { Receiver Elev. } \\
(\mathrm{m})\end{array}$ & Station No. & Shot Dist. $(\mathrm{m})$ & Shot Elev. $(\mathrm{m})$ \\
\hline 1 & 0 & 2.15 & 1 & 0 & 2.15 \\
\hline 2 & 5.05 & 1.63 & 2 & 5.05 & 1.63 \\
\hline
\end{tabular}




\begin{tabular}{|c|c|c|c|c|c|}
\hline 3 & 9.83 & 1.2 & 3 & 9.83 & 1.2 \\
\hline 4 & 14.6 & 0.75 & 4 & 14.6 & 0.75 \\
\hline 5 & 19.23 & 0.44 & 5 & 19.23 & 0.44 \\
\hline 6 & 24.05 & 0.34 & 6 & 24.05 & 0.34 \\
\hline 7 & 28.63 & 0.32 & 7 & 28.63 & 0.32 \\
\hline 8 & 33.51 & 0.29 & 8 & 33.51 & 0.29 \\
\hline 9 & 38.11 & 0.27 & 9 & 38.11 & 0.27 \\
\hline 10 & 42.57 & 0.22 & 10 & 42.57 & 0.22 \\
\hline 11 & 47.04 & 0.16 & 11 & 47.04 & 0.16 \\
\hline 12 & 51.55 & 0.18 & 12 & 51.55 & 0.18 \\
\hline 13 & 55.96 & 0.13 & 13 & 55.96 & 0.13 \\
\hline 14 & 60.49 & 0.11 & & & \\
\hline 15 & 65 & 0.18 & 15 & 65 & 0.18 \\
\hline 16 & 69.47 & 0.17 & 16 & 69.47 & 0.17 \\
\hline 17 & 73.92 & 0.17 & 17 & 73.92 & 0.17 \\
\hline 18 & 78.33 & 0.17 & 18 & 78.33 & 0.17 \\
\hline 19 & 82.86 & 0.18 & 19 & 82.86 & 0.18 \\
\hline 20 & 87.39 & 0.19 & 20 & 87.39 & 0.19 \\
\hline 21 & 91.92 & 0.2 & 21 & 91.92 & 0.2 \\
\hline 22 & 96.45 & 0.2 & 22 & 96.45 & 0.2 \\
\hline 23 & 100.86 & 0.19 & 23 & 100.86 & 0.19 \\
\hline 24 & 105.3 & 0.18 & 24 & 105.3 & 0.18 \\
\hline 25 & 109.76 & 0.15 & 25 & 109.76 & 0.15 \\
\hline 26 & 114.22 & 0.14 & 26 & 114.22 & 0.14 \\
\hline 27 & 118.88 & 0.12 & 27 & 118.88 & 0.12 \\
\hline 28 & 123.55 & 0.08 & 28 & 123.55 & 0.08 \\
\hline 29 & 128.71 & 0.13 & 29 & 128.71 & 0.13 \\
\hline 30 & 133.35 & 0.14 & 30 & 133.35 & 0.14 \\
\hline 31 & 138.36 & 0.18 & 31 & 138.36 & 0.18 \\
\hline 32 & 143.24 & 0.29 & 32 & 143.24 & 0.29 \\
\hline 33 & 148.14 & 0.26 & 33 & 148.14 & 0.26 \\
\hline 34 & 153.17 & 0.4 & 34 & 153.17 & 0.4 \\
\hline 35 & 158.28 & 0.46 & 35 & 158.28 & 0.46 \\
\hline 36 & 163.18 & 0.46 & & & \\
\hline 37 & 168.26 & 0.47 & 37 & 168.26 & 0.47 \\
\hline 38 & 173.29 & 0.55 & 38 & 173.29 & 0.55 \\
\hline 39 & 178.28 & 0.49 & 39 & 178.28 & 0.49 \\
\hline 40 & 183.23 & 0.53 & 40 & 183.23 & 0.53 \\
\hline 41 & 188.17 & 0.6 & 41 & 188.17 & 0.6 \\
\hline 42 & 193.31 & 0.65 & 42 & 193.31 & 0.65 \\
\hline 43 & 198.2 & 0.69 & 43 & 198.2 & 0.69 \\
\hline 44 & 203.22 & 0.57 & 44 & 203.22 & 0.57 \\
\hline 45 & 208.37 & 0.6 & 45 & 208.37 & 0.6 \\
\hline 46 & 213.13 & 0.65 & 46 & 213.13 & 0.65 \\
\hline 47 & 218.22 & 0.69 & 47 & 218.22 & 0.69 \\
\hline 48 & 223.16 & 0.66 & 48 & 223.16 & 0.66 \\
\hline 49 & 228.23 & 0.72 & 49 & 228.23 & 0.72 \\
\hline 50 & 233.25 & 0.76 & 50 & 233.25 & 0.76 \\
\hline 51 & 238.13 & 0.8 & & & \\
\hline 52 & 243.15 & 0.7 & 52 & 243.15 & 0.7 \\
\hline 53 & 248.03 & 0.8 & 53 & 248.03 & 0.8 \\
\hline 54 & 253.04 & 0.87 & 54 & 253.04 & 0.87 \\
\hline 55 & 258.04 & 0.85 & 55 & 258.04 & 0.85 \\
\hline 56 & 263.11 & 0.75 & 56 & 263.11 & 0.75 \\
\hline 57 & 268.02 & 0.93 & 57 & 268.02 & 0.93 \\
\hline 58 & 272.99 & 0.82 & 58 & 272.99 & 0.82 \\
\hline 59 & 277.98 & 0.92 & 59 & 277.98 & 0.92 \\
\hline 60 & 283.27 & 1.03 & 60 & 283.27 & 1.03 \\
\hline 61 & 288.09 & 1.03 & 61 & 288.09 & 1.03 \\
\hline 62 & 293.11 & 1.01 & 62 & 293.11 & 1.01 \\
\hline 63 & 298.08 & 1.02 & 63 & 298.08 & 1.02 \\
\hline 64 & 302.9 & 1.03 & 64 & 302.9 & 1.03 \\
\hline 65 & 307.56 & 1.02 & 65 & 307.56 & 1.02 \\
\hline 66 & 312.39 & 0.76 & 66 & 312.39 & 0.76 \\
\hline 67 & 317.54 & 0.74 & 67 & 317.54 & 0.74 \\
\hline 68 & 322.37 & 0.91 & 68 & 322.37 & 0.91 \\
\hline 69 & 327.34 & 0.94 & 69 & 327.34 & 0.94 \\
\hline 70 & 332.19 & 0.96 & 70 & 332.19 & 0.96 \\
\hline 71 & 337.05 & 0.94 & 71 & 337.05 & 0.94 \\
\hline 72 & 342.27 & 0.97 & 72 & 342.27 & 0.97 \\
\hline
\end{tabular}




\begin{tabular}{|c|c|c|c|c|c|}
\hline 73 & 347.28 & 0.91 & 73 & 347.28 & 0.91 \\
\hline 74 & 352.31 & 0.9 & 74 & 352.31 & 0.9 \\
\hline 75 & 357.27 & 0.92 & 75 & 357.27 & 0.92 \\
\hline 76 & 362.16 & 0.86 & 76 & 362.16 & 0.86 \\
\hline 77 & 367.07 & 0.83 & 77 & 367.07 & 0.83 \\
\hline 78 & 372.13 & 0.78 & 78 & 372.13 & 0.78 \\
\hline 79 & 377.12 & 0.74 & 79 & 377.12 & 0.74 \\
\hline 80 & 382.12 & 0.77 & 80 & 382.12 & 0.77 \\
\hline 81 & 387.06 & 0.8 & 81 & 387.06 & 0.8 \\
\hline 82 & 391.98 & 0.77 & 82 & 391.98 & 0.77 \\
\hline 83 & 396.61 & 0.64 & 83 & 396.61 & 0.64 \\
\hline 84 & 401.26 & 1.06 & 84 & 401.26 & 1.06 \\
\hline 85 & 405.72 & 1.07 & 85 & 405.72 & 1.07 \\
\hline 86 & 409.81 & 1.11 & 86 & 409.81 & 1.11 \\
\hline 87 & 414.04 & 1.03 & 87 & 414.04 & 1.03 \\
\hline 88 & 417.98 & 1.19 & 88 & 417.98 & 1.19 \\
\hline 89 & 422 & 1.18 & 89 & 422 & 1.18 \\
\hline 90 & 426.29 & 1.21 & 90 & 426.29 & 1.21 \\
\hline 91 & 429.87 & 1.22 & 91 & 429.87 & 1.22 \\
\hline 92 & 434.1 & 1.24 & 92 & 434.1 & 1.24 \\
\hline 93 & 438.4 & 1.63 & 93 & 438.4 & 1.63 \\
\hline 94 & 442.56 & 1.67 & 94 & 442.56 & 1.67 \\
\hline 95 & 446.86 & 1.79 & 95 & 446.86 & 1.79 \\
\hline 96 & 451.15 & 1.84 & 96 & 451.15 & 1.84 \\
\hline 97 & 455.59 & 1.87 & 97 & 455.59 & 1.87 \\
\hline 98 & 460.1 & 1.82 & 98 & 460.1 & 1.82 \\
\hline 99 & 464.68 & 1.93 & 99 & 464.68 & 1.93 \\
\hline 100 & 469.57 & 1.88 & 100 & 469.57 & 1.88 \\
\hline 101 & 474.5 & 1.91 & 101 & 474.5 & 1.91 \\
\hline 102 & 479.4 & 1.93 & 102 & 479.4 & 1.93 \\
\hline 103 & 484.34 & 1.92 & 103 & 484.34 & 1.92 \\
\hline 104 & 489.22 & 1.86 & 104 & 489.22 & 1.86 \\
\hline 105 & 494.28 & 1.85 & 105 & 494.28 & 1.85 \\
\hline 106 & 499.22 & 1.79 & 106 & 499.22 & 1.79 \\
\hline 107 & 504.16 & 1.83 & 107 & 504.16 & 1.83 \\
\hline 108 & 509.23 & 1.75 & 108 & 509.23 & 1.75 \\
\hline 109 & 514.21 & 1.8 & 109 & 514.21 & 1.8 \\
\hline 110 & 519.04 & 1.9 & 110 & 519.04 & 1.9 \\
\hline 111 & 524.03 & 1.87 & 111 & 524.03 & 1.87 \\
\hline 112 & 529.02 & 1.87 & 112 & 529.02 & 1.87 \\
\hline 113 & 533.91 & 1.91 & 113 & 533.91 & 1.91 \\
\hline 114 & 538.96 & 1.89 & 114 & 538.96 & 1.89 \\
\hline 115 & 543.81 & 1.9 & 115 & 543.81 & 1.9 \\
\hline 116 & 548.68 & 1.84 & 116 & 548.68 & 1.84 \\
\hline 117 & 553.8 & 1.89 & 117 & 553.8 & 1.89 \\
\hline 118 & 558.67 & 1.89 & 118 & 558.67 & 1.89 \\
\hline 119 & 563.72 & 1.99 & 119 & 563.72 & 1.99 \\
\hline 120 & 568.57 & 2.02 & & & \\
\hline 121 & 573.51 & 2 & 121 & 573.51 & 2 \\
\hline 122 & 578.68 & 2 & 122 & 578.68 & 2 \\
\hline 123 & 583.61 & 2.19 & 123 & 583.61 & 2.19 \\
\hline 124 & 588.62 & 2.2 & 124 & 588.62 & 2.2 \\
\hline 125 & 593.47 & 2.28 & 125 & 593.47 & 2.28 \\
\hline 126 & 598.64 & 2.33 & 126 & 598.64 & 2.33 \\
\hline 127 & 603.52 & 2.34 & 127 & 603.52 & 2.34 \\
\hline 128 & 608.67 & 2.5 & 128 & 608.67 & 2.5 \\
\hline 129 & 613.6 & 2.56 & 129 & 613.6 & 2.56 \\
\hline 130 & 618.56 & 2.55 & 130 & 618.56 & 2.55 \\
\hline 131 & 623.46 & 2.47 & 131 & 623.46 & 2.47 \\
\hline 132 & 628.24 & 2.46 & 132 & 628.24 & 2.46 \\
\hline 133 & 632.94 & 2.54 & 133 & 632.94 & 2.54 \\
\hline 134 & 637.57 & 2.44 & 134 & 637.57 & 2.44 \\
\hline 135 & 642.1 & 2.51 & 135 & 642.1 & 2.51 \\
\hline 136 & 646.7 & 2.42 & 136 & 646.7 & 2.42 \\
\hline 137 & 651.19 & 2.43 & 137 & 651.19 & 2.43 \\
\hline 138 & 655.34 & 2.42 & 138 & 655.34 & 2.42 \\
\hline 139 & 659.49 & 2.43 & 139 & 659.49 & 2.43 \\
\hline 140 & 663.18 & 2.48 & 140 & 663.18 & 2.48 \\
\hline 141 & 666.74 & 2.42 & 141 & 666.74 & 2.42 \\
\hline 142 & 670.55 & 2.44 & 142 & 670.55 & 2.44 \\
\hline
\end{tabular}




\begin{tabular}{|c|c|c|c|c|c|}
\hline 143 & 673.48 & 2.56 & 143 & 673.48 & 2.56 \\
\hline 144 & 677.08 & 2.81 & & & \\
\hline 145 & 680.76 & 3.47 & 145 & 680.76 & 3.47 \\
\hline 146 & 684.11 & 3.6 & 146 & 684.11 & 3.6 \\
\hline 147 & 687.5 & 3.7 & 147 & 687.5 & 3.7 \\
\hline 148 & 691.15 & 3.77 & 148 & 691.15 & 3.77 \\
\hline 149 & 694.31 & 3.81 & 149 & 694.31 & 3.81 \\
\hline 150 & 697.77 & 3.81 & 150 & 697.77 & 3.81 \\
\hline 151 & 701.18 & 3.81 & 151 & 701.18 & 3.81 \\
\hline 152 & 704.84 & 3.77 & 152 & 704.84 & 3.77 \\
\hline 153 & 708.34 & 3.85 & 153 & 708.34 & 3.85 \\
\hline 154 & 711.94 & 3.9 & & & \\
\hline 155 & 715.36 & 3.86 & & & \\
\hline 156 & 718.86 & 3.86 & & & \\
\hline 157 & 722.36 & 3.86 & & & \\
\hline 158 & 725.86 & 3.86 & & & \\
\hline 159 & 729.36 & 3.86 & & & \\
\hline
\end{tabular}

\section{Appendix D}

Distances and elevations along East Bay Seismic Profile 3 (SL-3).

Measurements are relative to the first shotpoint at the west end of Profile SL-3.

\begin{tabular}{|c|c|c|c|c|c|}
\hline Station No. & Receiver Dist. (m) & $\begin{array}{c}\text { Receiver Elev. } \\
(\mathrm{m})\end{array}$ & Station No. & Shot Dist. (m) & Shot Elev. (m) \\
\hline 1 & 0.22 & 0.04 & 1 & 0 & 0.41 \\
\hline 2 & 5.29 & 0.2 & 2 & 5.05 & 0.56 \\
\hline 3 & 10.09 & 0.24 & 3 & 9.84 & 0.59 \\
\hline 4 & 14.87 & 0.23 & 4 & 14.6 & 0.58 \\
\hline 5 & 19.82 & 0.23 & 5 & 19.54 & 0.57 \\
\hline 6 & 24.86 & 0.26 & 6 & 24.56 & 0.59 \\
\hline 7 & 29.79 & 0.12 & & & \\
\hline 8 & 34.52 & 0.25 & 8 & 34.19 & 0.56 \\
\hline 9 & 39.65 & 0.15 & 9 & 39.31 & 0.45 \\
\hline 10 & 44.44 & 0.19 & 10 & 44.08 & 0.49 \\
\hline 11 & 49.4 & 0 & & & \\
\hline 12 & 54.03 & 0.09 & 12 & 53.64 & 0.37 \\
\hline 13 & 58.84 & 0.22 & 13 & 58.44 & 0.49 \\
\hline 14 & 63.13 & 0.49 & 14 & 62.71 & 0.75 \\
\hline 15 & 67.45 & 0.49 & 15 & 67.02 & 0.75 \\
\hline 16 & 72.03 & 0.61 & 16 & 71.58 & 0.86 \\
\hline 17 & 76.74 & 0.6 & 17 & 76.28 & 0.84 \\
\hline 18 & 81.14 & 0.51 & 18 & 80.66 & 0.74 \\
\hline 19 & 85.77 & 0.44 & 19 & 85.28 & 0.66 \\
\hline 20 & 90.24 & 0.35 & 20 & 89.73 & 0.57 \\
\hline 21 & 94.63 & 0.43 & 21 & 94.11 & 0.64 \\
\hline 22 & 99.28 & 0.52 & 22 & 98.74 & 0.72 \\
\hline 23 & 103.68 & 0.65 & 23 & 103.13 & 0.84 \\
\hline 24 & 108.21 & 0.68 & 24 & 107.64 & 0.86 \\
\hline 25 & 112.61 & 1.11 & 25 & 112.03 & 1.28 \\
\hline 26 & 116.62 & 1.66 & 26 & 116.02 & 1.83 \\
\hline 27 & 121.08 & 2.16 & 27 & 120.47 & 2.32 \\
\hline 28 & 125.73 & 2.15 & 28 & 125.1 & 2.3 \\
\hline 29 & 130.29 & 1.71 & 29 & 130.2 & 1.99 \\
\hline 30 & 135.05 & 1.24 & 30 & 135.2 & 1.33 \\
\hline 31 & 140 & 1.02 & 31 & 140.17 & 1.15 \\
\hline 32 & 144.99 & 1.03 & 32 & 145.02 & 1.18 \\
\hline 33 & 149.96 & 1.03 & 33 & 149.8 & 1.2 \\
\hline 34 & 154.85 & 1.04 & 34 & 154.76 & 1.19 \\
\hline 35 & 159.85 & 1.02 & 35 & 159.88 & 1.11 \\
\hline 36 & 164.55 & 0.99 & 36 & 164.64 & 1.12 \\
\hline 37 & 169.66 & 1.03 & & & \\
\hline 38 & 174.34 & 0.94 & 38 & 174.44 & 1.17 \\
\hline 39 & 178.88 & 0.96 & 39 & 179.27 & 1.03 \\
\hline 40 & 183.66 & 0.8 & 40 & 183.94 & 0.98 \\
\hline 41 & 188.16 & 0.89 & 41 & 188.49 & 0.97 \\
\hline 42 & 192.56 & 0.86 & 42 & 192.83 & 1.03 \\
\hline 43 & 197.1 & 0.79 & 43 & 197.37 & 0.95 \\
\hline 44 & 201.57 & 1 & 44 & 201.9 & 0.98 \\
\hline
\end{tabular}




\begin{tabular}{|c|c|c|c|c|c|}
\hline 45 & 205.96 & 1.24 & 45 & 206.25 & 1.24 \\
\hline 46 & 210.51 & 1 & 46 & 210.77 & 1.02 \\
\hline 47 & 215.09 & 1.04 & 47 & 215.31 & 1.08 \\
\hline 48 & 219.53 & 0.94 & 48 & 219.72 & 1 \\
\hline 49 & 223.99 & 0.88 & 49 & 224.14 & 0.96 \\
\hline 50 & 228.68 & 0.69 & 50 & 228.8 & 0.79 \\
\hline 51 & 233.22 & 0.54 & 51 & 233.3 & 0.66 \\
\hline 52 & 238.04 & 0.75 & 52 & 238.09 & 0.89 \\
\hline 53 & 242.9 & 0.47 & 53 & 242.91 & 0.63 \\
\hline 54 & 247.98 & 0.52 & 54 & 247.96 & 0.7 \\
\hline 55 & 252.85 & 0.54 & 55 & 252.8 & 0.74 \\
\hline 56 & 257.79 & 0.53 & 56 & 257.7 & 0.75 \\
\hline 57 & 263.07 & 0.61 & 57 & 262.74 & 0.79 \\
\hline 58 & 267.89 & 0.6 & 58 & 267.56 & 0.79 \\
\hline 59 & 272.85 & 0.79 & 59 & 272.56 & 0.83 \\
\hline 60 & 277.68 & 0.88 & 60 & 277.28 & 0.88 \\
\hline 61 & 282.54 & 0.82 & 61 & 281.96 & 0.9 \\
\hline 62 & 286.84 & 1.08 & 62 & 286.21 & 0.93 \\
\hline 63 & 291.56 & 0.9 & 63 & 290.97 & 1.1 \\
\hline 64 & 296.01 & 0.97 & 64 & 295.37 & 1.27 \\
\hline 65 & 300.35 & 1.03 & 65 & 299.64 & 1.39 \\
\hline 66 & 304.71 & 1.04 & 66 & 304.03 & 1.36 \\
\hline 67 & 308.8 & 1.03 & 67 & 308.14 & 1.32 \\
\hline 68 & 312.87 & 1.12 & 68 & 312.24 & 1.37 \\
\hline 69 & 317.2 & 1.34 & 69 & 316.6 & 1.55 \\
\hline 70 & 321.43 & 1.31 & 70 & 320.86 & 1.48 \\
\hline 71 & 325.63 & 1.45 & 71 & 325.08 & 1.59 \\
\hline 72 & 329.83 & 1.5 & 72 & 329.31 & 1.6 \\
\hline 73 & 334.23 & 1.59 & 73 & 333.53 & 1.66 \\
\hline 74 & 338.5 & 1.66 & 74 & 337.86 & 1.84 \\
\hline 75 & 343.01 & 1.71 & 75 & 342.48 & 1.88 \\
\hline 76 & 347.57 & 1.71 & 76 & 347.17 & 1.82 \\
\hline 77 & 352.3 & 1.75 & 77 & 352.03 & 1.85 \\
\hline 78 & 357.09 & 1.76 & 78 & 356.76 & 1.87 \\
\hline 79 & 361.86 & 1.78 & 79 & 361.65 & 1.83 \\
\hline 80 & 366.71 & 1.82 & 80 & 366.53 & 1.92 \\
\hline 81 & 371.8 & 1.82 & 81 & 371.64 & 1.96 \\
\hline 82 & 376.66 & 1.84 & 82 & 376.64 & 1.98 \\
\hline 83 & 381.58 & 1.84 & 83 & 381.56 & 1.95 \\
\hline 84 & 386.48 & 1.77 & & & \\
\hline 85 & 391.43 & 1.82 & & & \\
\hline 86 & 396.32 & 1.83 & 86 & 396.34 & 1.92 \\
\hline 87 & 400.92 & 2.04 & & & \\
\hline 88 & 405.54 & 2.13 & 88 & 405.76 & 2.23 \\
\hline 89 & 409.76 & 1.76 & 89 & 410 & 1.87 \\
\hline 90 & 414.28 & 1.59 & & & \\
\hline 91 & 419.32 & 1.61 & 91 & 419.58 & 1.74 \\
\hline 92 & 423.59 & 1.6 & & & \\
\hline 93 & 428.17 & 1.56 & 93 & 428.46 & 1.71 \\
\hline 94 & 433.07 & 1.56 & & & \\
\hline 95 & 437.6 & 1.49 & & & \\
\hline 96 & 442.05 & 1.54 & 96 & 442.38 & 1.72 \\
\hline 97 & 446.33 & 1.59 & 97 & 446.67 & 1.78 \\
\hline 98 & 450.93 & 1.6 & 98 & 451.39 & 1.72 \\
\hline 99 & 455.53 & 1.56 & & & \\
\hline 100 & 460.07 & 1.51 & 100 & 460.53 & 1.68 \\
\hline 101 & 464.55 & 1.49 & 101 & 465 & 1.61 \\
\hline 102 & 469.27 & 1.46 & 102 & 469.61 & 1.58 \\
\hline 103 & 474.25 & 1.42 & 103 & 474.59 & 1.62 \\
\hline 104 & 478.99 & 1.41 & 104 & 479.21 & 1.61 \\
\hline 105 & 484 & 1.49 & 105 & 483.96 & 1.58 \\
\hline 106 & 488.97 & 1.47 & 106 & 488.91 & 1.57 \\
\hline 107 & 493.99 & 1.67 & 107 & 493.92 & 1.78 \\
\hline 108 & 499.05 & 1.66 & 108 & 498.96 & 1.78 \\
\hline 109 & 504.08 & 1.72 & 109 & 503.98 & 1.85 \\
\hline 110 & 509.12 & 1.83 & 110 & 509 & 1.97 \\
\hline 111 & 514.04 & 1.81 & 111 & 513.9 & 1.96 \\
\hline 112 & 519.33 & 1.79 & 112 & 519.18 & 1.95 \\
\hline 113 & 524.19 & 1.88 & 113 & 524.02 & 2.05 \\
\hline 114 & 529.17 & 1.94 & 114 & 528.99 & 2.12 \\
\hline
\end{tabular}




\begin{tabular}{|c|c|c|c|c|c|}
\hline 115 & 534.95 & 2.02 & 115 & 534.75 & 2.21 \\
\hline 116 & 538.7 & 2.06 & 116 & 538.92 & 2.14 \\
\hline 117 & 543.78 & 2.15 & 117 & 543.46 & 2.21 \\
\hline 118 & 548.12 & 2.19 & 118 & 548.4 & 2.31 \\
\hline 119 & 553.42 & 2.14 & & & \\
\hline 120 & 558.36 & 2.13 & & & \\
\hline 121 & 562.8 & 2.06 & & & \\
\hline 122 & 567.65 & 2.06 & 122 & 567.94 & 2.21 \\
\hline 123 & 572.63 & 2.03 & 123 & 572.87 & 2.18 \\
\hline 124 & 577.3 & 2.05 & 124 & 577.49 & 2.19 \\
\hline 125 & 582.34 & 2.04 & 125 & 582.48 & 2.18 \\
\hline 126 & 587.01 & 2.05 & 126 & 587.1 & 2.19 \\
\hline 127 & 591.5 & 2.25 & 127 & 591.54 & 2.39 \\
\hline 128 & 596.12 & 2.34 & 128 & 596.52 & 2.59 \\
\hline 129 & 600.92 & 2.38 & 129 & 601.08 & 2.57 \\
\hline 130 & 605.84 & 2.37 & 130 & 606.19 & 2.59 \\
\hline 131 & 610.59 & 2.48 & 131 & 610.93 & 2.46 \\
\hline 132 & 615.22 & 2.36 & 132 & 615.56 & 2.35 \\
\hline 133 & 620.19 & 2.3 & 133 & 620.53 & 2.3 \\
\hline 134 & 625.06 & 2.31 & 134 & 625.4 & 2.33 \\
\hline 135 & 629.63 & 2.24 & 135 & 629.96 & 2.27 \\
\hline 136 & 634.38 & 2.24 & 136 & 634.71 & 2.28 \\
\hline 137 & 639.24 & 2.2 & 137 & 639.57 & 2.25 \\
\hline 138 & 643.85 & 2.16 & 138 & 644.18 & 2.23 \\
\hline 139 & 648.96 & 2.24 & 139 & 649.29 & 2.32 \\
\hline 140 & 653.75 & 2.31 & 140 & 654.09 & 2.3 \\
\hline 141 & 658.15 & 2.29 & 141 & 658.46 & 2.28 \\
\hline 142 & 663.35 & 2.43 & 142 & 663.63 & 2.42 \\
\hline 143 & 667.95 & 2.46 & 143 & 668.19 & 2.46 \\
\hline 144 & 672.73 & 2.41 & 144 & 672.94 & 2.41 \\
\hline
\end{tabular}

\section{Appendix E}

Distances and elevations along East Bay Seismic Profile 4 (SL-4).

Measurements are relative to the first receiver point at the west end of Profile SL-4.

\begin{tabular}{|c|c|c|c|c|c|}
\hline Station No. & Receiver Dist. (m) & $\begin{array}{c}\text { Receiver Elev. } \\
(\mathrm{m})\end{array}$ & Station No. & Shot Dist. (m) & Shot Elev. (m) \\
\hline 1 & 0 & 0.99 & & & \\
\hline 2 & 5.07 & 1.39 & 2 & 5.21 & 1.22 \\
\hline 3 & 10.56 & 1.2 & 3 & 10.27 & 1.22 \\
\hline 4 & 15.21 & 1.12 & 4 & 14.91 & 1.15 \\
\hline 5 & 20.16 & 1.12 & & & \\
\hline 6 & 25.15 & 1.19 & & & \\
\hline 7 & 30.1 & 1.08 & & & \\
\hline 8 & 35.13 & 1.07 & & & \\
\hline 9 & 40.17 & 1.17 & & & \\
\hline 10 & 44.99 & 1.29 & & & \\
\hline 11 & 50.02 & 1.3 & & & \\
\hline 12 & 55.16 & 1.38 & & & \\
\hline 13 & 60.02 & 1.47 & & & \\
\hline 14 & 65.06 & 1.52 & & & \\
\hline 15 & 70.19 & 1.56 & & & \\
\hline 16 & 75.01 & 1.59 & & & \\
\hline 17 & 80 & 1.52 & & & \\
\hline 18 & 85.09 & 1.51 & & & \\
\hline 19 & 90.08 & 1.49 & & & \\
\hline 20 & 95.12 & 1.4 & & & \\
\hline 21 & 99.94 & 1.31 & & & \\
\hline 22 & 104.98 & 1.2 & & & \\
\hline 23 & 110.06 & 1.19 & & & \\
\hline 24 & 115.11 & 1.03 & & & \\
\hline 25 & 120.01 & 1.1 & & & \\
\hline 26 & 125.63 & 1.14 & & & \\
\hline 27 & 130.09 & 1.15 & & & \\
\hline 28 & 135.13 & 1.17 & & & \\
\hline 29 & 140 & 1.07 & & & \\
\hline 30 & 145.04 & 0.98 & & & \\
\hline 31 & 149.94 & 0.82 & & & \\
\hline
\end{tabular}




\begin{tabular}{|c|c|c|c|c|c|}
\hline 32 & 154.98 & 0.7 & 32 & 155 & 0.63 \\
\hline 33 & 160.07 & 0.73 & 33 & 160.22 & 0.69 \\
\hline 34 & 164.44 & 0.76 & 34 & 164.46 & 0.7 \\
\hline 35 & 169.84 & 0.72 & 35 & 170.21 & 0.7 \\
\hline 36 & 174.92 & 0.77 & 36 & 174.94 & 0.71 \\
\hline 37 & 179.91 & 0.72 & 37 & 179.97 & 0.7 \\
\hline 38 & 184.95 & 0.71 & 38 & 184.97 & 0.67 \\
\hline 39 & 190.25 & 0.69 & 39 & 190.1 & 0.7 \\
\hline 40 & 194.94 & 0.68 & 40 & 195.05 & 0.66 \\
\hline 41 & 199.93 & 0.68 & 41 & 199.83 & 0.67 \\
\hline 42 & 204.88 & 0.65 & 42 & 204.86 & 0.63 \\
\hline 43 & 209.93 & 0.63 & 43 & 210.04 & 0.62 \\
\hline 44 & 214.92 & 0.56 & 44 & 214.9 & 0.51 \\
\hline 45 & 219.95 & 0.57 & 45 & 219.71 & 0.54 \\
\hline 46 & 224.82 & 0.55 & 46 & 225.15 & 0.58 \\
\hline 47 & 230.26 & 0.55 & 47 & 230.2 & 0.56 \\
\hline 48 & 234.9 & 0.57 & 48 & 235.02 & 0.56 \\
\hline 49 & 239.89 & 0.55 & 49 & 240.09 & 0.55 \\
\hline 50 & 244.89 & 0.56 & 50 & 244.96 & 0.55 \\
\hline 51 & 249.88 & 0.64 & 51 & 249.96 & 0.62 \\
\hline 52 & 254.92 & 0.65 & 52 & 254.72 & 0.63 \\
\hline 53 & 259.92 & 0.56 & 53 & 259.85 & 0.52 \\
\hline 54 & 264.95 & 0.37 & 54 & 264.97 & 0.5 \\
\hline 55 & 269.91 & 0.48 & & & \\
\hline
\end{tabular}

\section{Appendix F}

Distances and elevations along East Bay Seismic Profile 5 (SL-5).

Measurements are relative to the first receiver point at the west end of Profile SL-5.

\begin{tabular}{|c|c|c|c|c|c|}
\hline Station No. & Receiver Dist. (m) & $\begin{array}{l}\text { Receiver Elev. } \\
(\mathrm{m})\end{array}$ & Station No. & Shot Dist. (m) & Shot Elev. (m) \\
\hline 1 & 0.04 & 0.14 & & & \\
\hline 2 & 5.05 & 0.15 & & & \\
\hline 3 & 9.62 & 0.3 & & & \\
\hline 4 & 14.71 & 0.53 & & & \\
\hline 5 & 19.04 & 0.47 & & & \\
\hline 6 & 24.46 & 0.44 & & & \\
\hline 7 & 30.5 & 0.51 & & & \\
\hline 8 & 35.04 & 0.46 & & & \\
\hline 9 & 40 & 0.41 & 9 & 40.06 & 0.37 \\
\hline 10 & 44.93 & 0.37 & 10 & 44.86 & 0.34 \\
\hline 11 & 49.86 & 0.44 & 11 & 49.71 & 0.41 \\
\hline 12 & 54.87 & 0.56 & 12 & 54.77 & 0.56 \\
\hline 13 & 59.78 & 0.69 & 13 & 59.84 & 0.68 \\
\hline 14 & 64.89 & 0.77 & 14 & 64.74 & 0.76 \\
\hline 15 & 69.95 & 0.78 & & & \\
\hline 16 & 74.91 & 0.79 & 16 & 74.87 & 0.82 \\
\hline 17 & 79.96 & 0.87 & 17 & 79.91 & 0.89 \\
\hline 18 & 84.98 & 0.83 & 18 & 84.92 & 0.85 \\
\hline 19 & 89.83 & 0.89 & 19 & 89.83 & 0.88 \\
\hline 20 & 94.83 & 0.96 & & & \\
\hline 21 & 99.84 & 0.92 & 21 & 99.95 & 0.95 \\
\hline 22 & 104.9 & 1.04 & 22 & 104.96 & 1.05 \\
\hline 23 & 109.91 & 1.07 & 23 & 110.14 & 1.1 \\
\hline 24 & 114.87 & 1.14 & 24 & 114.83 & 1.1 \\
\hline 25 & 119.88 & 1.16 & 25 & 119.9 & 1.15 \\
\hline 26 & 124.9 & 1.17 & 26 & 124.9 & 1.15 \\
\hline 27 & 129.95 & 1.17 & 27 & 129.51 & 1.09 \\
\hline 28 & 135 & 1.21 & 28 & 134.93 & 1.18 \\
\hline 29 & 139.81 & 1.22 & 29 & 139.82 & 1.17 \\
\hline 30 & 144.86 & 1.28 & 30 & 144.83 & 1.26 \\
\hline 31 & 149.87 & 1.24 & 31 & 149.63 & 1.23 \\
\hline 32 & 154.67 & 1.23 & & & \\
\hline 33 & 159.73 & 1.21 & 33 & 159.81 & 1.17 \\
\hline 34 & 164.74 & 1.18 & 34 & 164.61 & 1.14 \\
\hline 35 & 169.8 & 1.13 & 35 & 169.81 & 1.12 \\
\hline 36 & 174.76 & 1.1 & 36 & 174.84 & 1.03 \\
\hline 37 & 179.86 & 1.08 & 37 & 179.69 & 1.07 \\
\hline
\end{tabular}




\begin{tabular}{|c|c|c|c|c|c|}
\hline 38 & 184.83 & 0.99 & 38 & 184.79 & 0.96 \\
\hline 39 & 189.79 & 0.91 & 39 & 189.89 & 0.9 \\
\hline 40 & 194.87 & 0.91 & 40 & 194.77 & 0.88 \\
\hline 41 & 199.83 & 0.88 & 41 & 199.68 & 0.91 \\
\hline 42 & 204.79 & 0.86 & 42 & 204.8 & 0.9 \\
\hline 43 & 209.8 & 0.86 & & & \\
\hline 44 & 214.72 & 0.83 & 44 & 214.68 & 0.88 \\
\hline 45 & 219.68 & 0.86 & 45 & 219.9 & 0.85 \\
\hline 46 & 224.85 & 0.89 & 46 & 224.81 & 0.88 \\
\hline 47 & 229.76 & 0.88 & 47 & 229.68 & 0.88 \\
\hline 48 & 234.73 & 0.89 & 48 & 234.6 & 0.86 \\
\hline 49 & 239.64 & 0.83 & 49 & 239.65 & 0.81 \\
\hline 50 & 244.86 & 0.77 & & & \\
\hline 51 & 250.03 & 0.75 & & & \\
\hline 52 & 254.8 & 0.69 & & & \\
\hline 53 & 259.63 & 0.65 & & & \\
\hline 54 & 264.63 & 0.65 & 54 & 264.74 & 0.64 \\
\hline 55 & 269.48 & 1.26 & & & \\
\hline 56 & 274.56 & 0.87 & & & \\
\hline 57 & 279.64 & 0.47 & & & \\
\hline 58 & 284.38 & 0.46 & 58 & 284.44 & 0.43 \\
\hline
\end{tabular}

\section{Appendix G}

Distances and elevations along East Bay Seismic Profile 6 (SL-6).

Measurements are relative to the first receiver point at the west end of Profile SL-6.

\begin{tabular}{|c|c|c|c|c|c|}
\hline Station No. & Receiver Dist. (m) & $\begin{array}{c}\text { Receiver Elev. } \\
(\mathrm{m})\end{array}$ & Station No. & Shot Dist. (m) & Shot Elev. (m) \\
\hline 1 & 0 & 0.07 & 1 & 0 & 0.07 \\
\hline 2 & 5.64 & 0.17 & 2 & 5.64 & 0.17 \\
\hline 3 & 10.36 & 0 & 3 & 10.36 & 0 \\
\hline 4 & 15.4 & 0.05 & 4 & 15.4 & 0.05 \\
\hline 5 & 20.66 & 0.05 & 5 & 20.66 & 0.05 \\
\hline 6 & 25.52 & 0.16 & 6 & 25.52 & 0.16 \\
\hline 7 & 30.43 & 0.17 & 7 & 30.43 & 0.17 \\
\hline 8 & 35.47 & 0.19 & 8 & 35.47 & 0.19 \\
\hline 9 & 40.51 & 0.2 & 9 & 40.51 & 0.2 \\
\hline 10 & 45.46 & 0.25 & 10 & 45.46 & 0.25 \\
\hline 11 & 50.37 & 0.28 & 11 & 50.37 & 0.28 \\
\hline 12 & 55.54 & 0.26 & 12 & 55.54 & 0.26 \\
\hline 13 & 60.32 & 0.32 & 13 & 60.32 & 0.32 \\
\hline 14 & 65.4 & 0.29 & 14 & 65.4 & 0.29 \\
\hline 15 & 70.53 & 0.24 & 15 & 70.53 & 0.24 \\
\hline 16 & 75.48 & 0.07 & 16 & 75.48 & 0.07 \\
\hline 17 & 80.42 & 0.3 & 17 & 80.42 & 0.3 \\
\hline 18 & 85.45 & 0.24 & 18 & 85.45 & 0.24 \\
\hline 19 & 90.38 & 0.17 & 19 & 90.38 & 0.17 \\
\hline 20 & 95.42 & 0.13 & 20 & 95.42 & 0.13 \\
\hline 21 & 100.42 & 0.54 & 21 & 100.42 & 0.54 \\
\hline 22 & 105.24 & 0.16 & 22 & 105.24 & 0.16 \\
\hline 23 & 110.41 & 0.12 & 23 & 110.41 & 0.12 \\
\hline 24 & 115.36 & 0.26 & 24 & 115.36 & 0.26 \\
\hline 25 & 120.14 & 0.21 & 25 & 120.14 & 0.21 \\
\hline 26 & 125.57 & 0.24 & 26 & 125.57 & 0.24 \\
\hline 27 & 130.35 & 0.28 & 27 & 130.35 & 0.28 \\
\hline 28 & 134.94 & 0.29 & 28 & 134.94 & 0.29 \\
\hline 29 & 140.43 & 0.31 & 29 & 140.43 & 0.31 \\
\hline 30 & 145.33 & 0.48 & 30 & 145.33 & 0.48 \\
\hline 31 & 150.41 & 0.34 & 31 & 150.41 & 0.34 \\
\hline 32 & 155.28 & 0.37 & 32 & 155.28 & 0.37 \\
\hline 33 & 160.24 & 0.34 & 33 & 160.24 & 0.34 \\
\hline 34 & 165.32 & 0.4 & 34 & 165.32 & 0.4 \\
\hline 35 & 170.44 & 0.35 & 35 & 170.44 & 0.35 \\
\hline 36 & 175.42 & 0.36 & 36 & 175.42 & 0.36 \\
\hline 37 & 180.22 & 0.37 & 37 & 180.22 & 0.37 \\
\hline 38 & 185.26 & 0.42 & 38 & 185.26 & 0.42 \\
\hline 39 & 190.3 & 0.46 & 39 & 190.3 & 0.46 \\
\hline 40 & 195.2 & 0.47 & 40 & 195.2 & 0.47 \\
\hline
\end{tabular}




\begin{tabular}{|c|c|c|c|c|c|}
\hline 41 & 200.2 & 0.34 & 41 & 200.2 & 0.34 \\
\hline 42 & 205.11 & 0.1 & 42 & 205.11 & 0.1 \\
\hline 43 & 210.24 & 0.46 & 43 & 210.24 & 0.46 \\
\hline 44 & 215.32 & 0.47 & 44 & 215.32 & 0.47 \\
\hline 45 & 220.27 & 0.41 & 45 & 220.27 & 0.41 \\
\hline 46 & 225.05 & 0.11 & 46 & 225.05 & 0.11 \\
\hline 47 & 230.3 & 0.57 & 47 & 230.3 & 0.57 \\
\hline 48 & 235.21 & 0.57 & 48 & 235.21 & 0.57 \\
\hline 49 & 240.3 & 0.51 & 49 & 240.3 & 0.51 \\
\hline 50 & 245.25 & 0.55 & 50 & 245.25 & 0.55 \\
\hline 51 & 250.33 & 0.54 & 51 & 250.33 & 0.54 \\
\hline 52 & 255.23 & 0.54 & 52 & 255.23 & 0.54 \\
\hline 53 & 260.18 & 0.54 & 53 & 260.18 & 0.54 \\
\hline 54 & 265.27 & 0.51 & 54 & 265.27 & 0.51 \\
\hline 55 & 270.22 & 0.57 & 55 & 270.22 & 0.57 \\
\hline 56 & 275.31 & 0.6 & 56 & 275.31 & 0.6 \\
\hline 57 & 280.21 & 0.54 & 57 & 280.21 & 0.54 \\
\hline 58 & 285.34 & 0.59 & 58 & 285.34 & 0.59 \\
\hline 59 & 290.24 & 0.56 & 59 & 290.24 & 0.56 \\
\hline 60 & 295.25 & 0.61 & 60 & 295.25 & 0.61 \\
\hline 61 & 300.15 & 0.65 & 61 & 300.15 & 0.65 \\
\hline 62 & 305.28 & 0.64 & 62 & 305.28 & 0.64 \\
\hline 63 & 310.18 & 0.69 & 63 & 310.18 & 0.69 \\
\hline 64 & 315.49 & 0.6 & 64 & 315.49 & 0.6 \\
\hline 65 & 320.19 & 0.76 & 65 & 320.19 & 0.76 \\
\hline 66 & 325.23 & 0.71 & 66 & 325.23 & 0.71 \\
\hline 67 & 330.24 & 0.76 & 67 & 330.24 & 0.76 \\
\hline 68 & 335.32 & 0.8 & 68 & 335.32 & 0.8 \\
\hline 69 & 340.18 & 0.74 & 69 & 340.18 & 0.74 \\
\hline 70 & 345.08 & 0.78 & 70 & 345.08 & 0.78 \\
\hline 71 & 350.05 & 0.92 & 71 & 350.05 & 0.92 \\
\hline 72 & 355.22 & 0.93 & 72 & 355.22 & 0.93 \\
\hline 73 & 360.31 & 0.89 & & & \\
\hline 74 & 365.71 & 0.93 & 74 & 365.71 & 0.93 \\
\hline 75 & 370.31 & 0.95 & 75 & 370.31 & 0.95 \\
\hline 76 & 375.07 & 1.04 & 76 & 375.07 & 1.04 \\
\hline 77 & 380.16 & 1.05 & 77 & 380.16 & 1.05 \\
\hline 78 & 385.24 & 1.08 & 78 & 385.24 & 1.08 \\
\hline 79 & 390.06 & 1.13 & 79 & 390.06 & 1.13 \\
\hline 80 & 395.05 & 1.1 & 80 & 395.05 & 1.1 \\
\hline 81 & 400.07 & 0.87 & 81 & 400.07 & 0.87 \\
\hline 82 & 404.36 & 0.98 & 82 & 404.36 & 0.98 \\
\hline 83 & 408.81 & 1.01 & 83 & 408.81 & 1.01 \\
\hline 84 & 412.39 & 1.16 & & & \\
\hline 85 & 417.79 & 1.23 & 85 & 417.79 & 1.23 \\
\hline 86 & 420.3 & 1.31 & 86 & 420.3 & 1.31 \\
\hline 87 & 425.2 & 1.37 & 87 & 425.2 & 1.37 \\
\hline 88 & 429.82 & 1.42 & 88 & 429.82 & 1.42 \\
\hline 89 & 435.19 & 1.41 & 89 & 435.19 & 1.41 \\
\hline 90 & 440.01 & 1.5 & 90 & 440.01 & 1.5 \\
\hline 91 & 445.09 & 1.54 & 91 & 445.09 & 1.54 \\
\hline 92 & 449.96 & 1.64 & 92 & 449.96 & 1.64 \\
\hline 93 & 454.87 & 1.75 & 93 & 454.87 & 1.75 \\
\hline 94 & 459.95 & 1.92 & 94 & 459.95 & 1.92 \\
\hline 95 & 464.9 & 2.09 & 95 & 464.9 & 2.09 \\
\hline 96 & 470.04 & 2.19 & 96 & 470.04 & 2.19 \\
\hline 97 & 474.95 & 2.5 & 97 & 474.95 & 2.5 \\
\hline 98 & 479.85 & 2.8 & 98 & 479.85 & 2.8 \\
\hline 99 & 484.84 & 3.1 & 99 & 484.84 & 3.1 \\
\hline 100 & 489.88 & 3.38 & 100 & 489.88 & 3.38 \\
\hline 101 & 494.89 & 3.74 & 101 & 494.89 & 3.74 \\
\hline 102 & 499.75 & 4.08 & 102 & 499.75 & 4.08 \\
\hline 103 & 504.8 & 4.53 & 103 & 504.8 & 4.53 \\
\hline 104 & 509.84 & 4.9 & 104 & 509.84 & 4.9 \\
\hline 105 & 514.79 & 5.5 & 105 & 514.79 & 5.5 \\
\hline 106 & 519.88 & 5.9 & 106 & 519.88 & 5.9 \\
\hline 107 & 524.61 & 6.22 & 107 & 524.61 & 6.22 \\
\hline 108 & 529.82 & 6.72 & 108 & 529.82 & 6.72 \\
\hline 109 & 534.73 & 7.11 & 109 & 534.73 & 7.11 \\
\hline 110 & 539.86 & 7.6 & 110 & 539.86 & 7.6 \\
\hline
\end{tabular}




\begin{tabular}{|c|c|c|c|c|c|}
\hline 111 & 544.77 & 8.13 & 111 & 544.77 & 8.13 \\
\hline 112 & 549.89 & 8.58 & 112 & 549.89 & 8.58 \\
\hline 113 & 554.8 & 9.05 & 113 & 554.8 & 9.05 \\
\hline 114 & 559.42 & 9.5 & 114 & 559.42 & 9.5 \\
\hline 115 & 564.38 & 9.93 & 115 & 564.38 & 9.93 \\
\hline 116 & 569.29 & 10.43 & 116 & 569.29 & 10.43 \\
\hline 117 & 574.19 & 10.98 & 117 & 574.19 & 10.98 \\
\hline
\end{tabular}




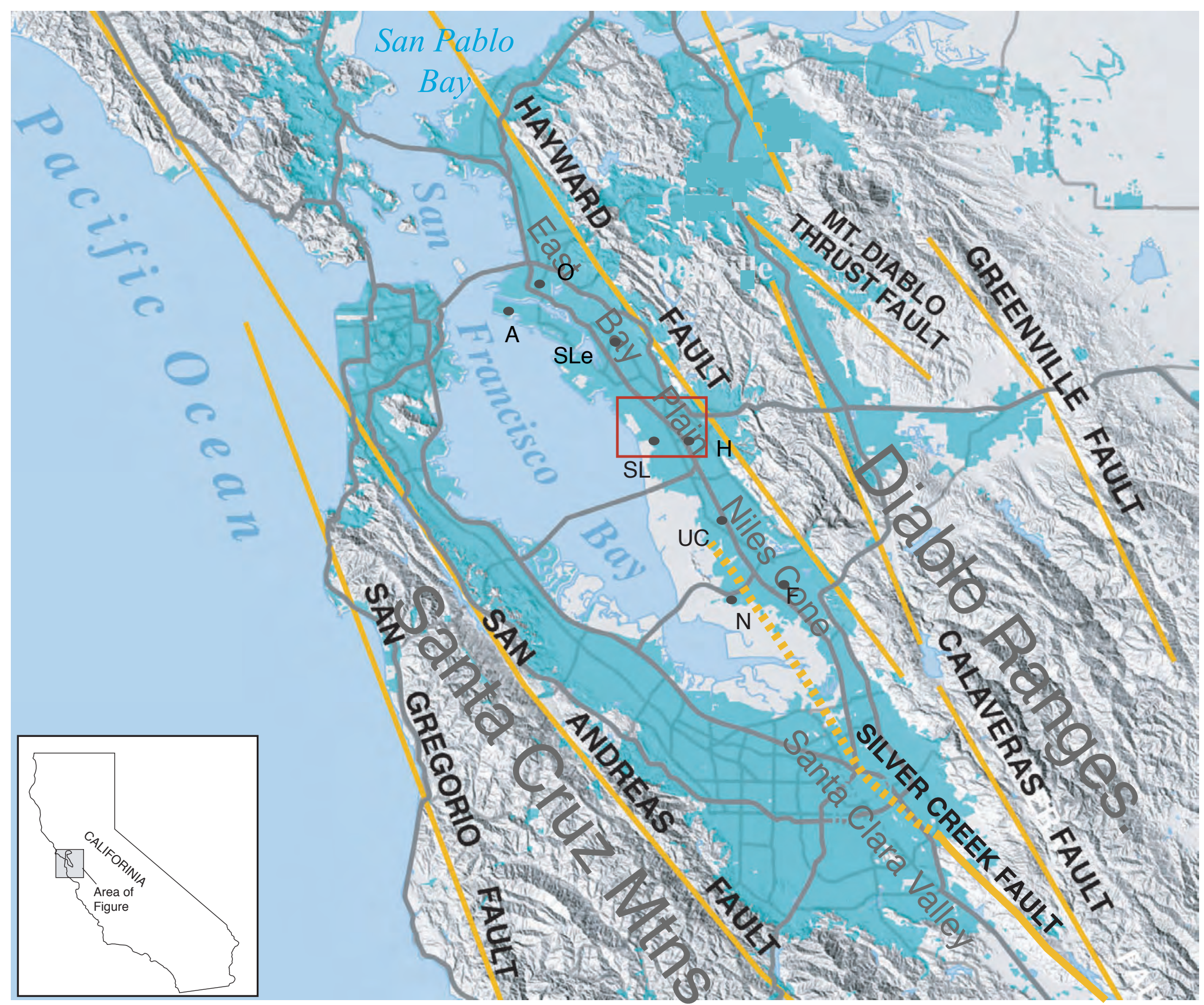


East Bay Plain Seismic Transect

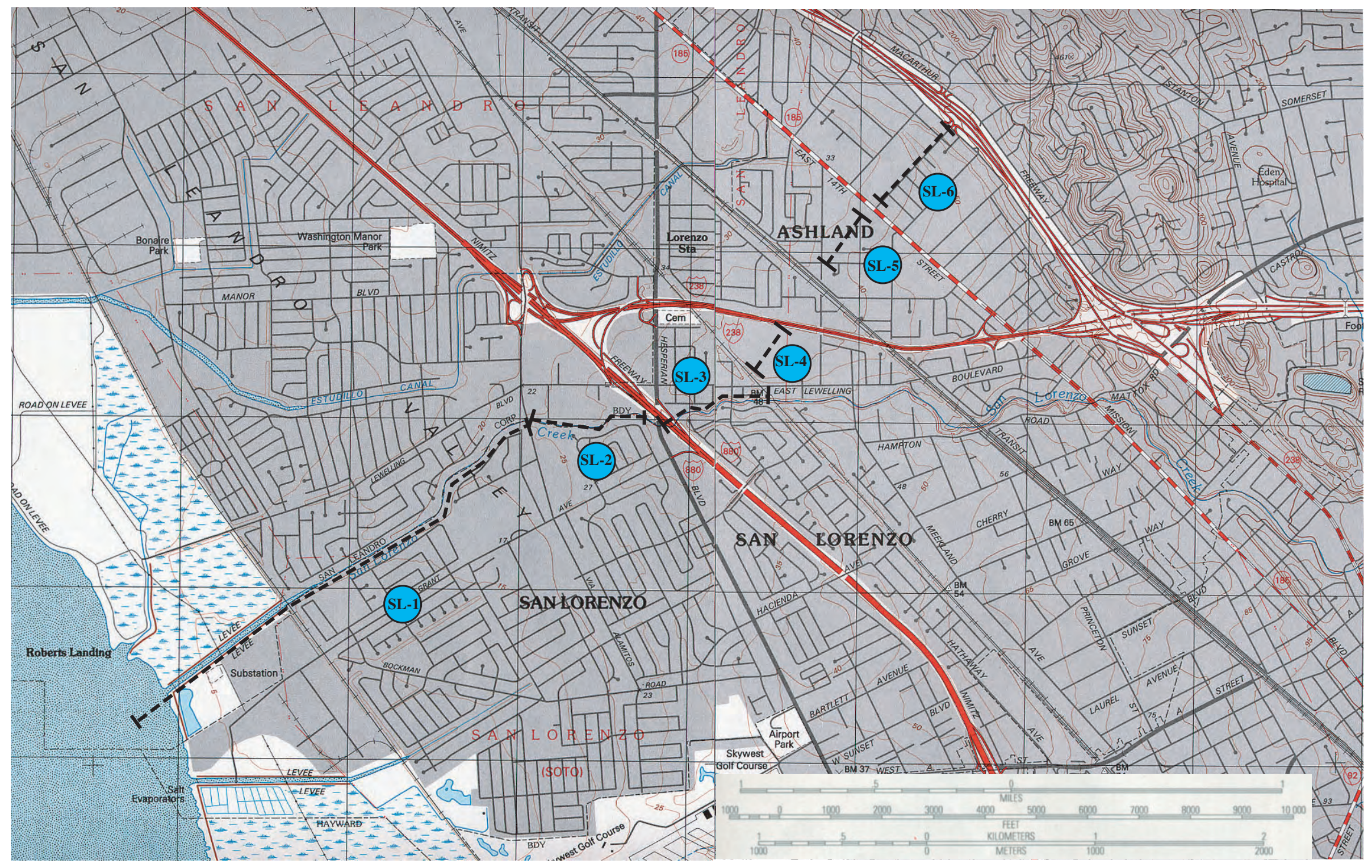

Fig. 2 


\section{Profile SL-1}
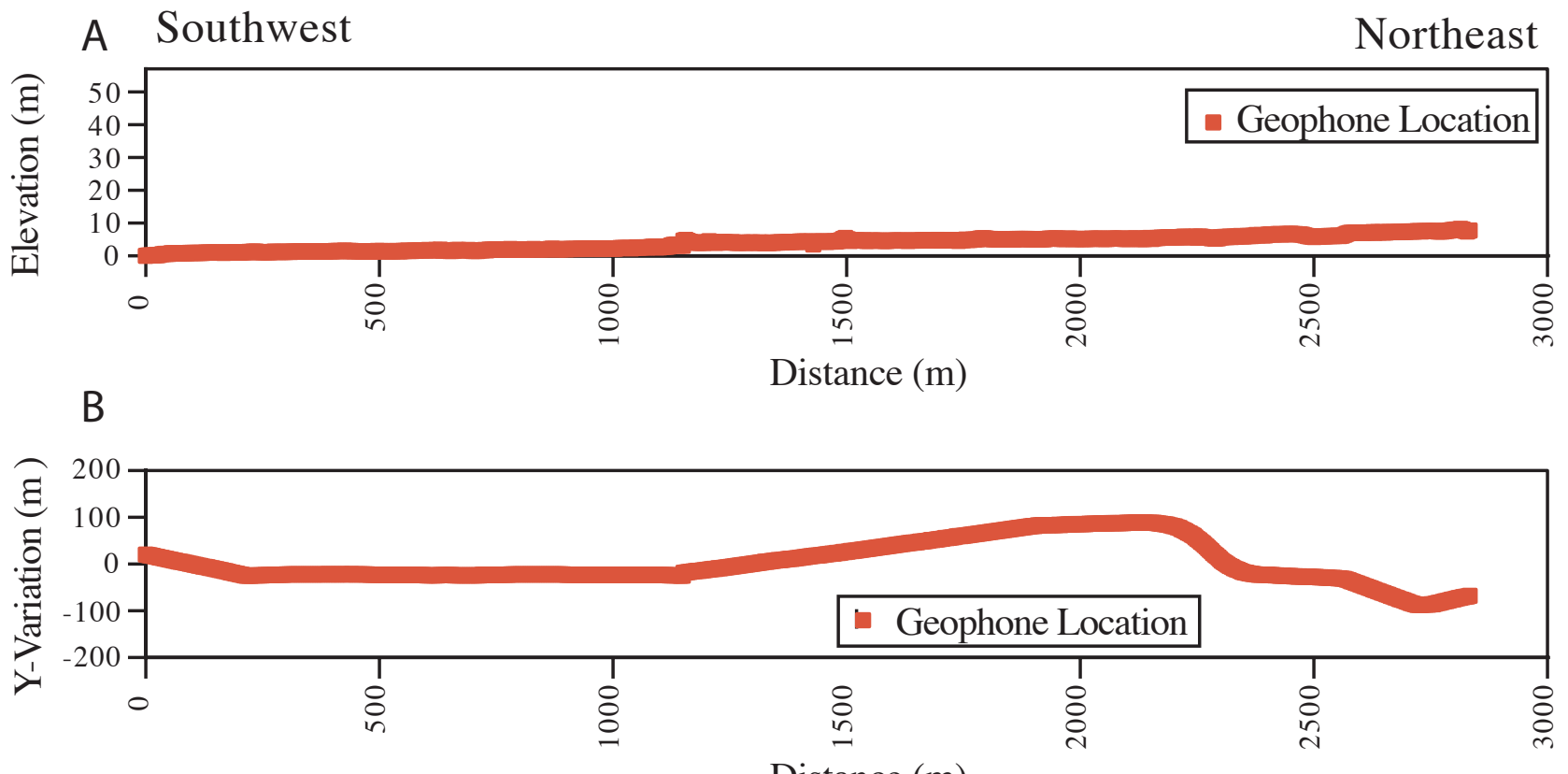

Distance (m)

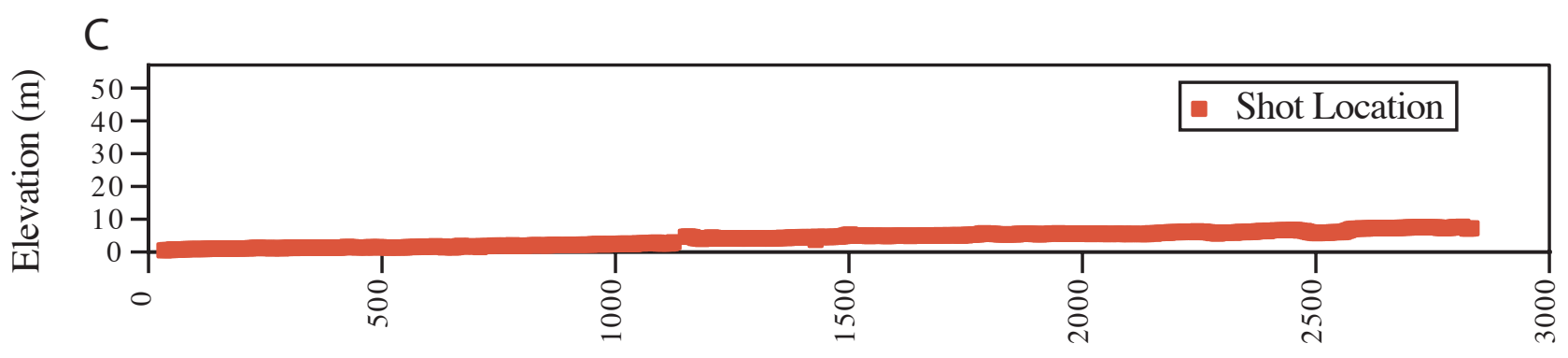

D

Distance (m)

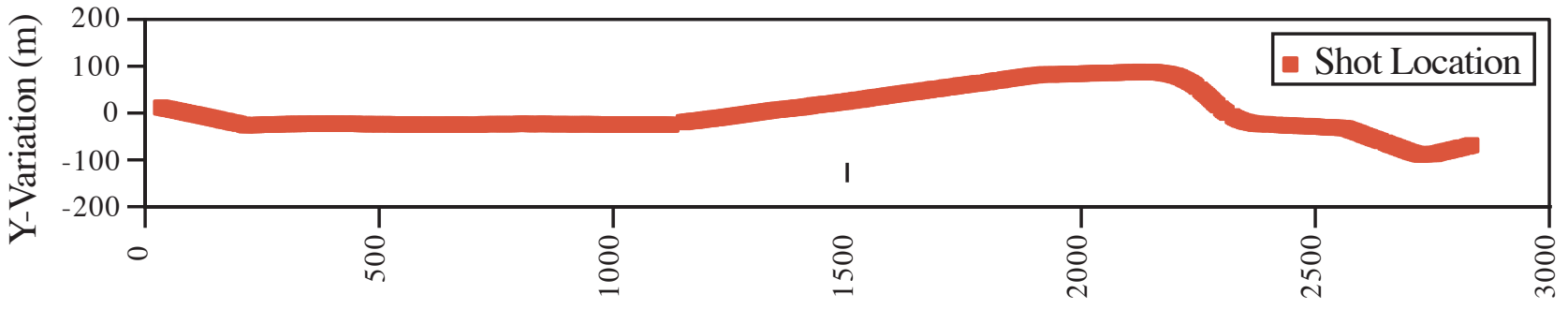

Distance (m)

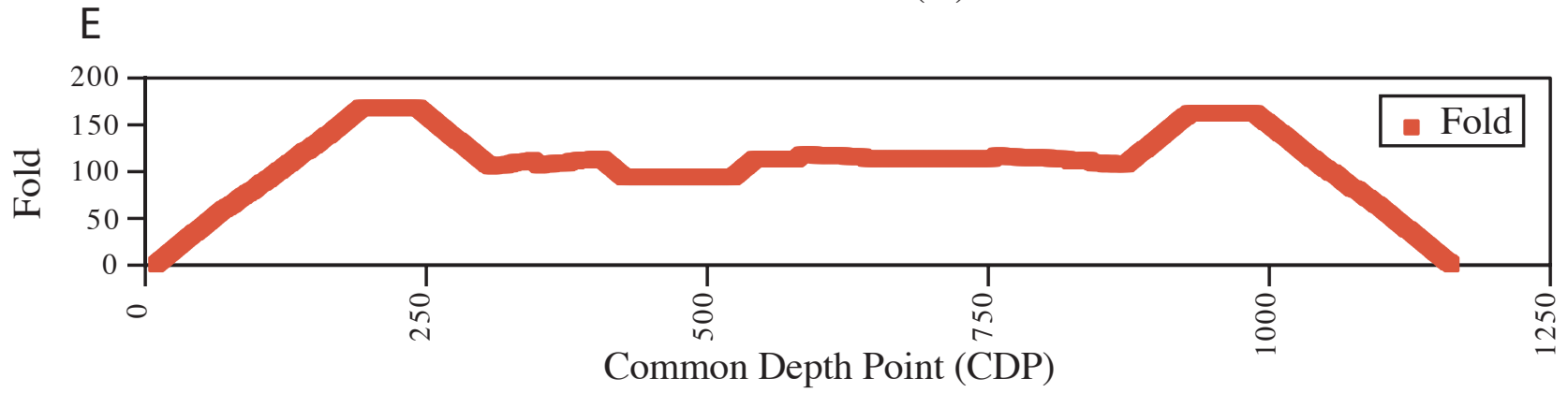

Fig. 3 


\section{Profile SL-2}
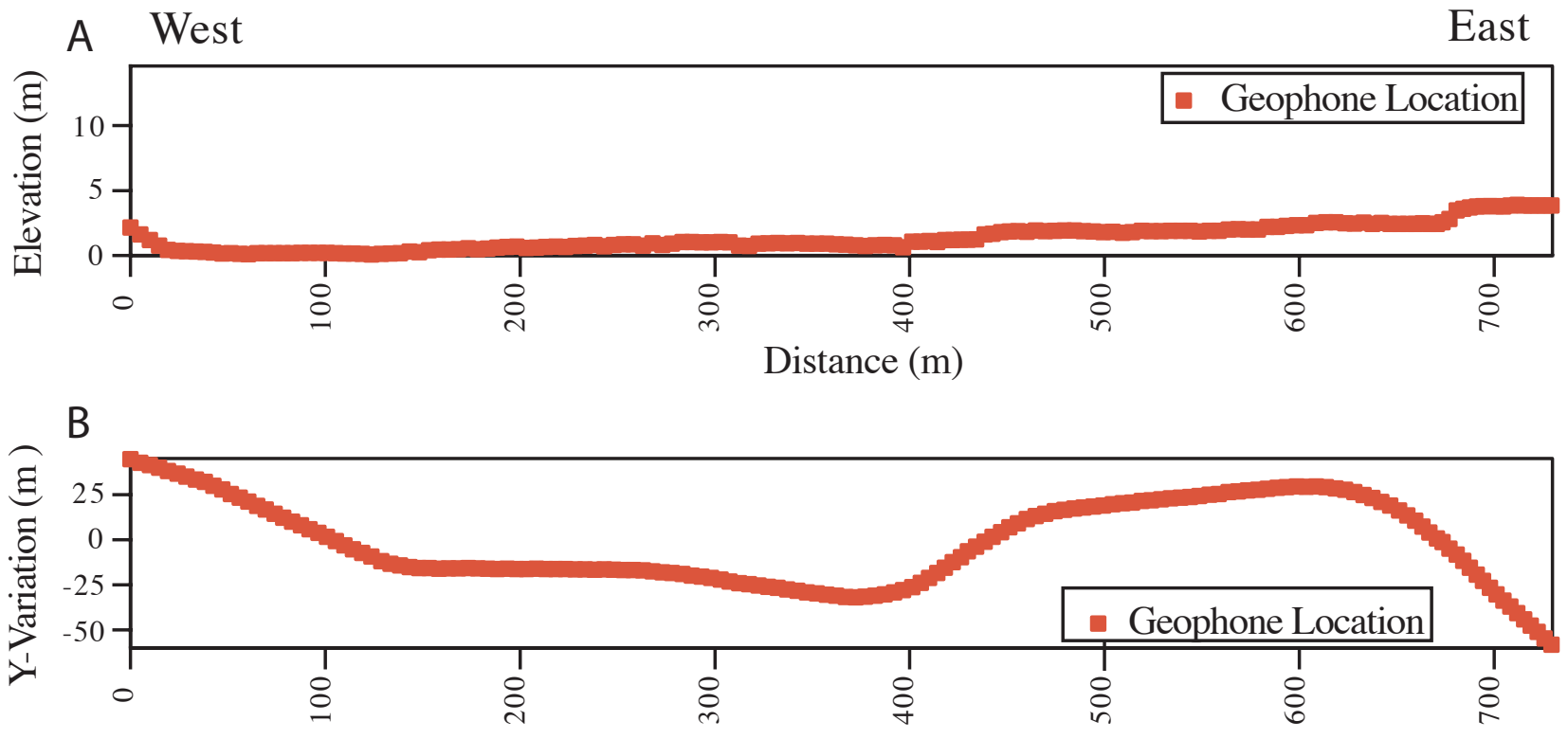

Distance (m)

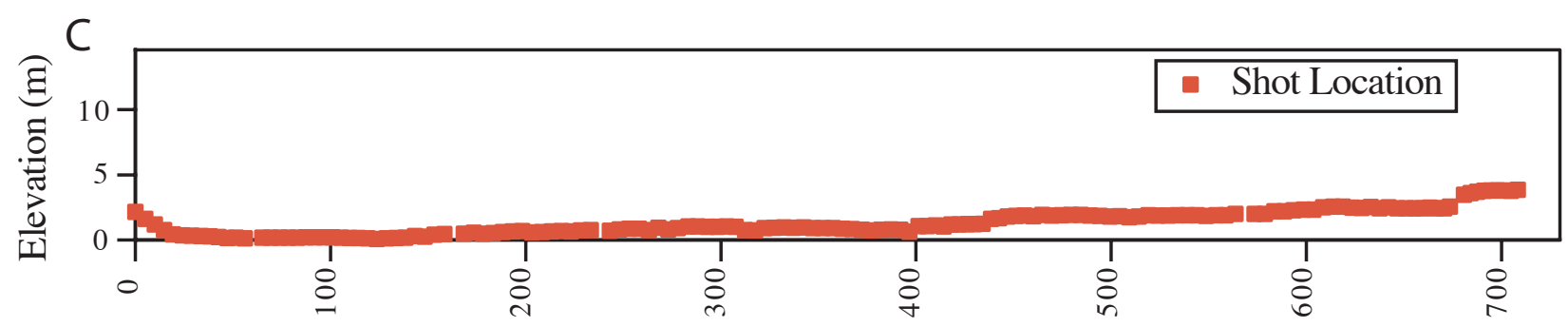

Distance (m)

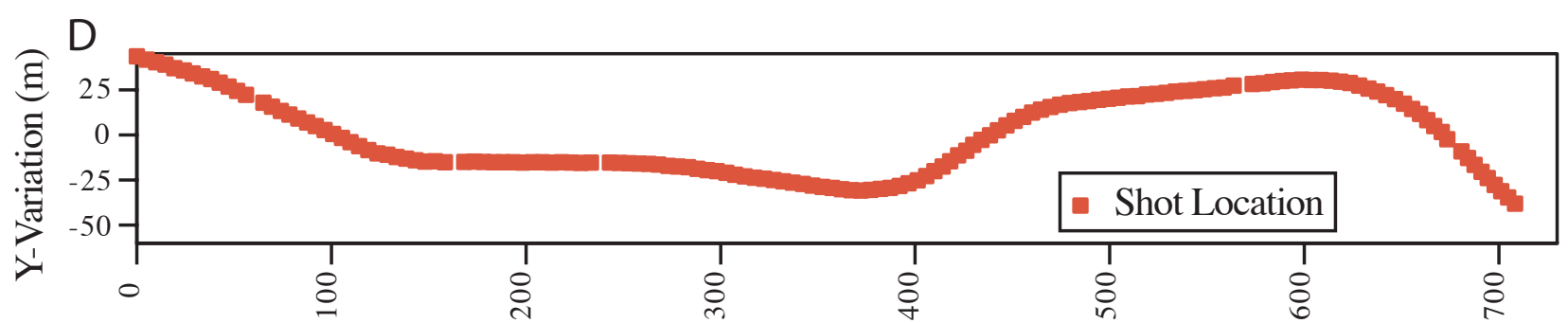

Distance (m)

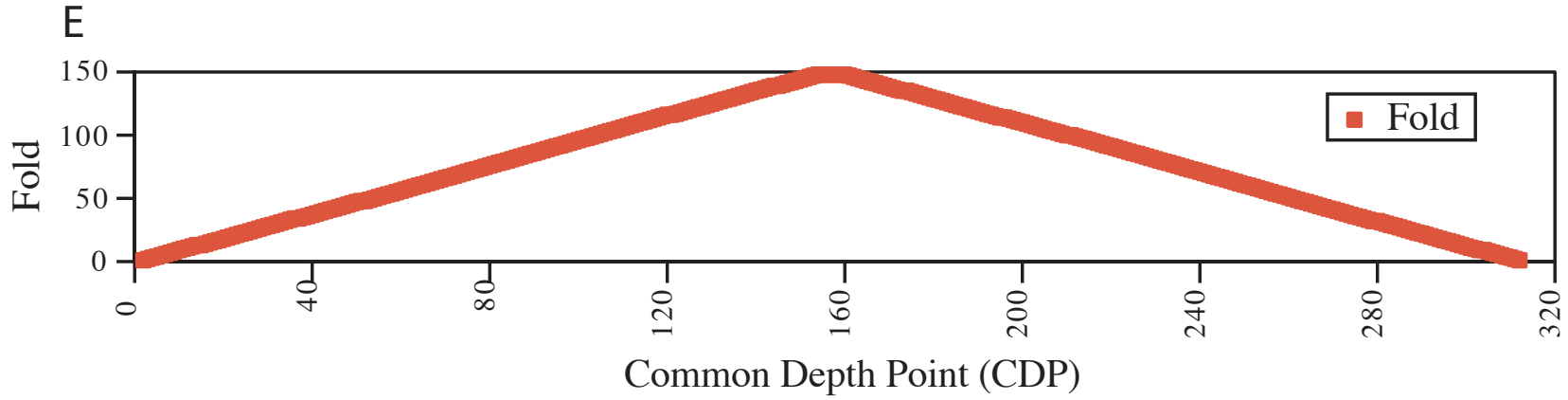

Fig. 4 


\section{Profile SL-3}

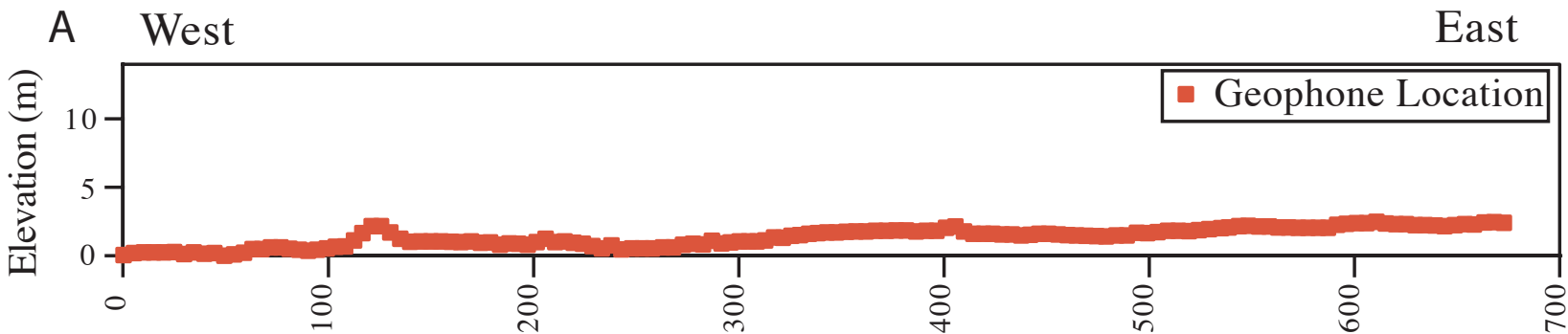

B

Distance (m)

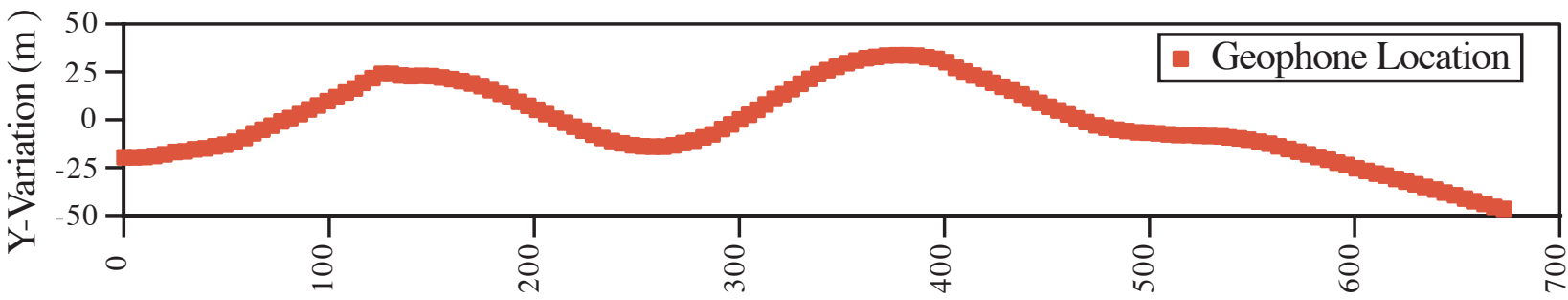

Distance (m)

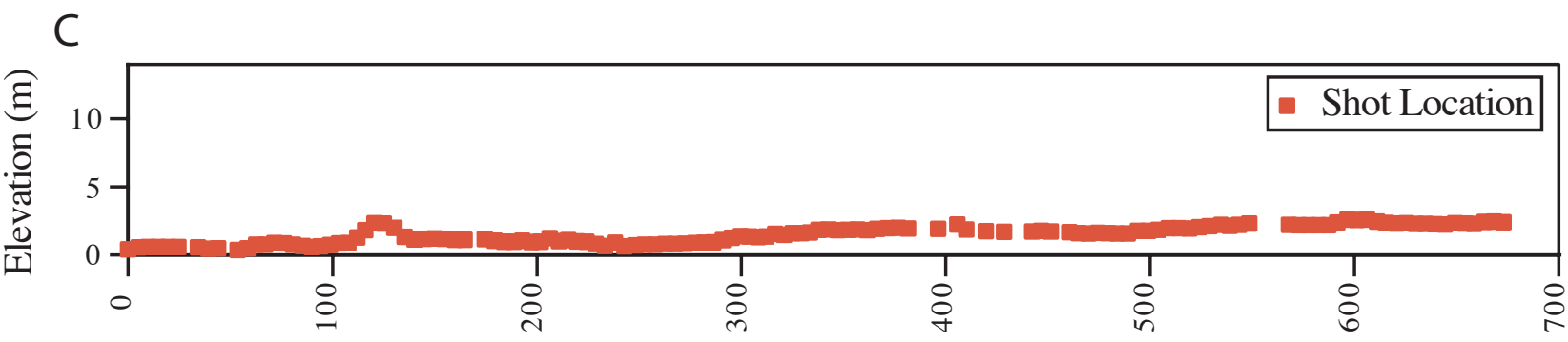

Distance (m)

D

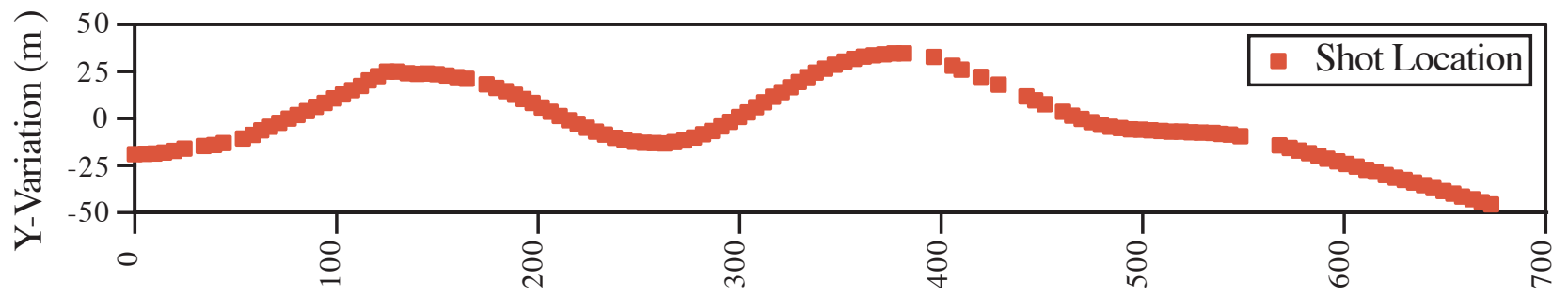

Distance (m)

\section{E}

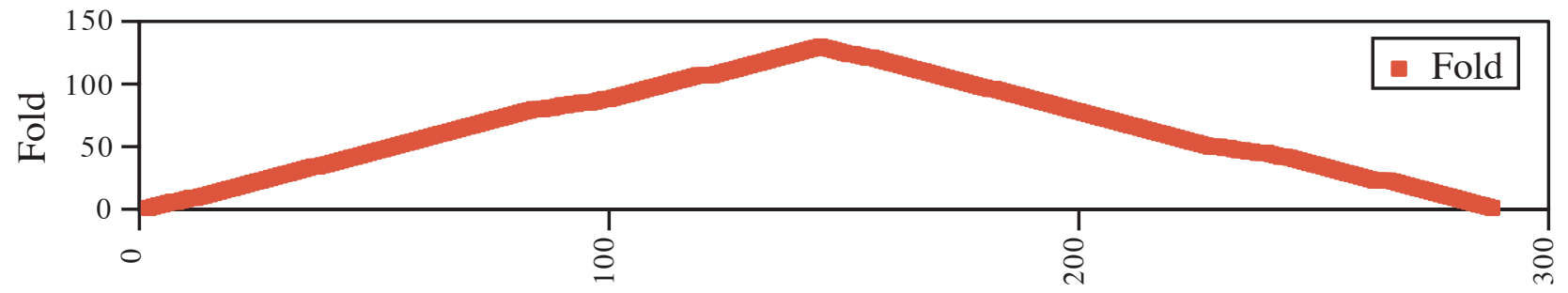

Common Depth Point (CDP)

Fig. 5 


\section{Profile SL-4}

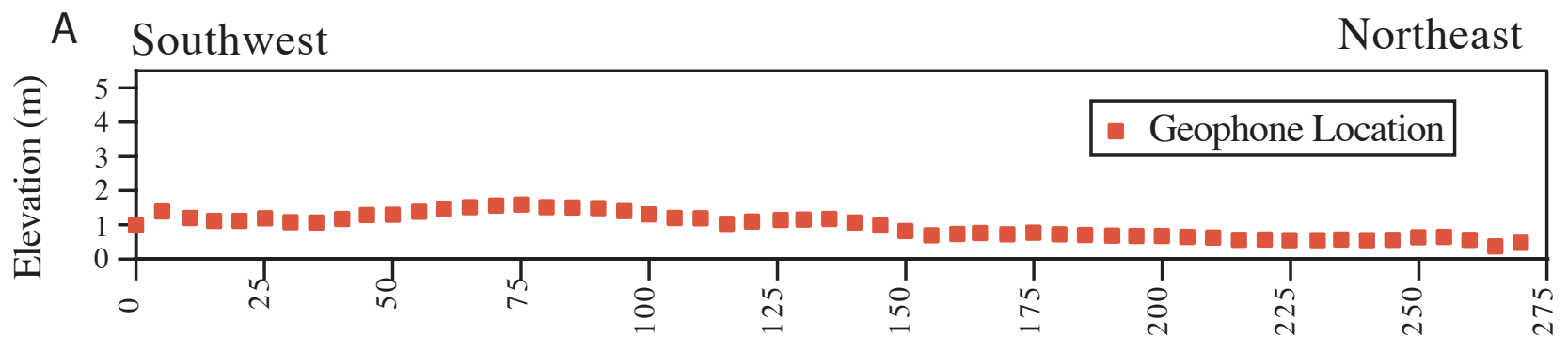

B

Distance (m)

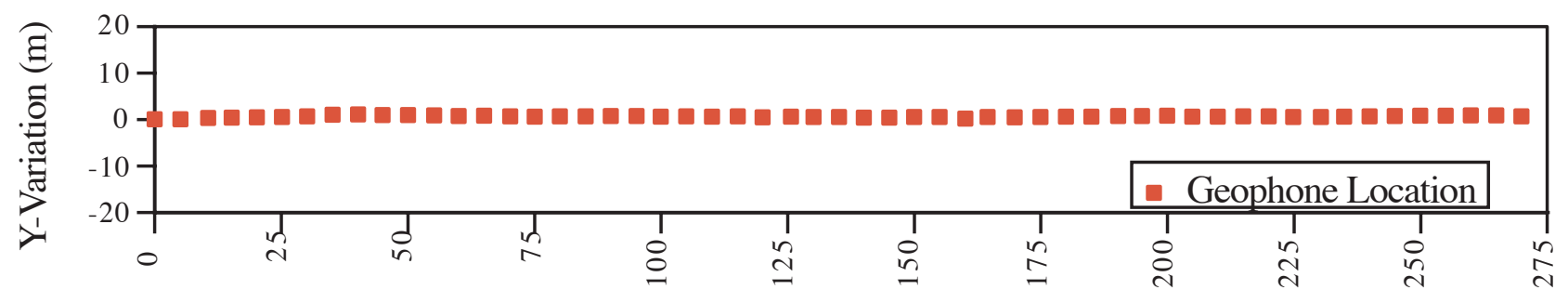

Distance (m)

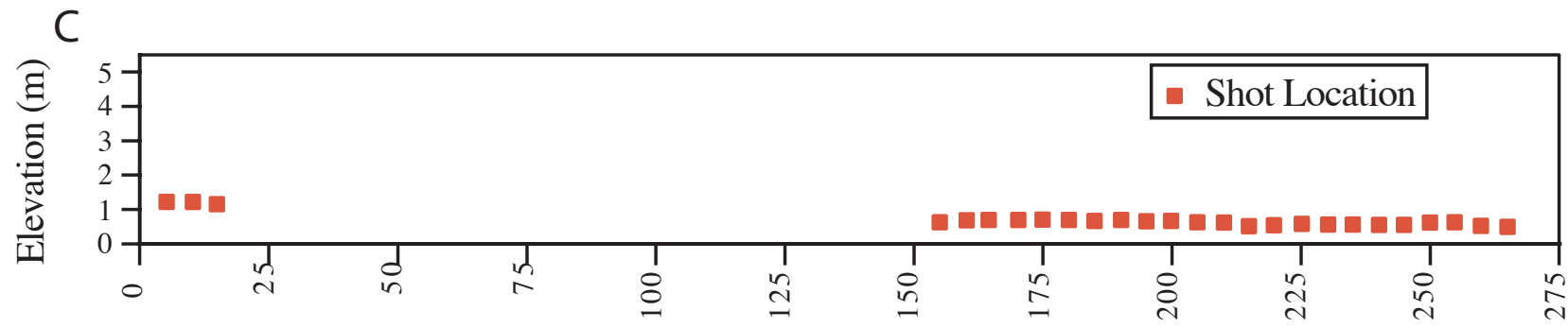

D

Distance (m)

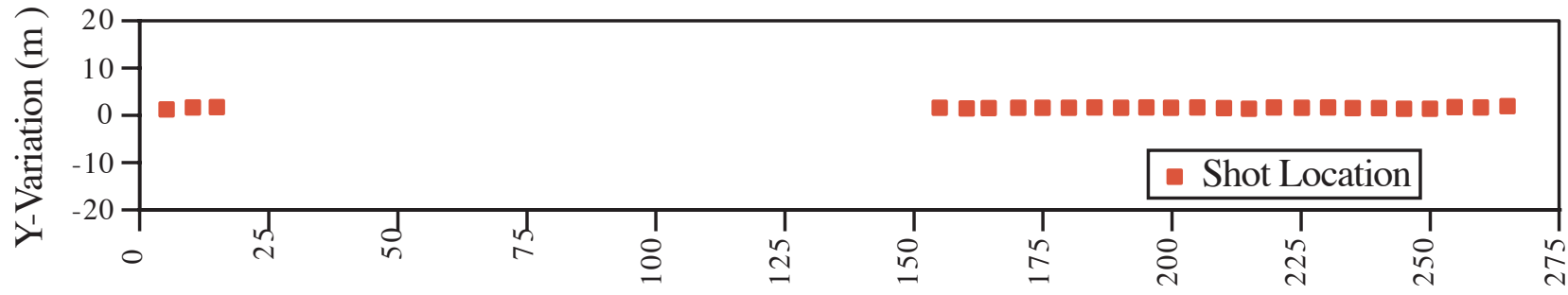

Distance (m)

E

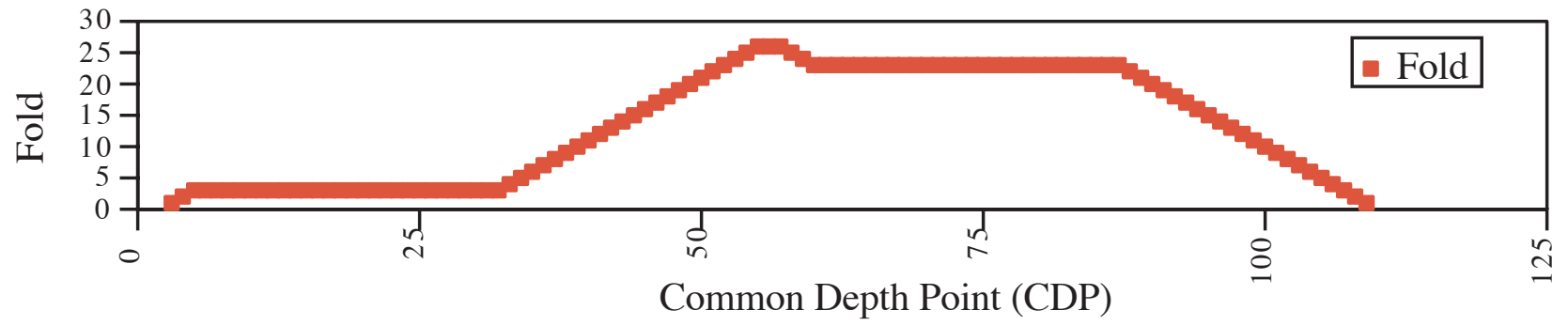

Fig. 6 
Profile SL-5

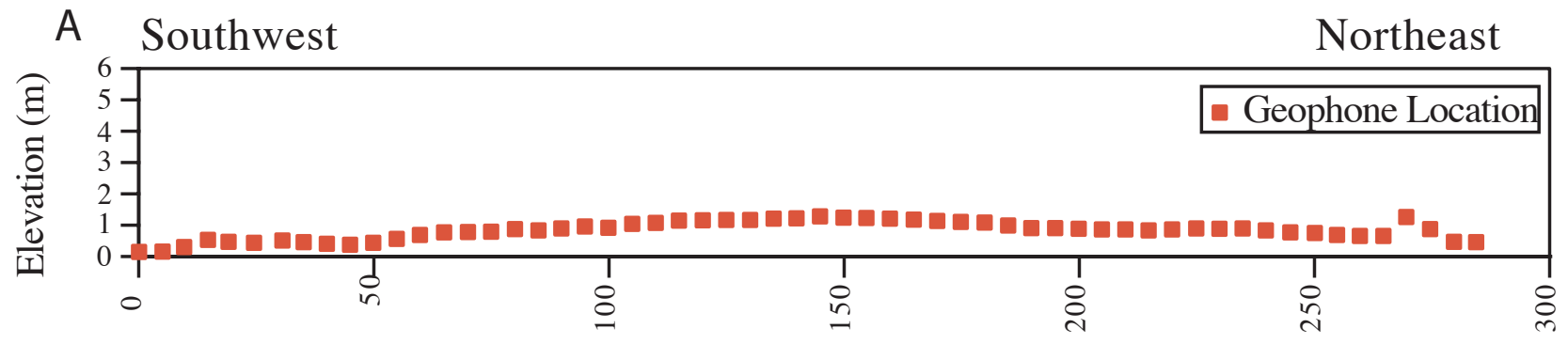

Distance (m)

B

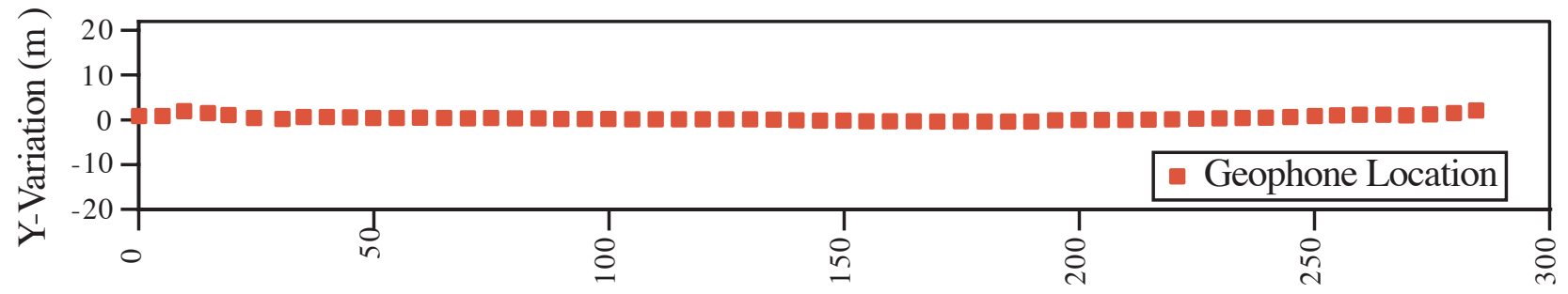

Distance (m)

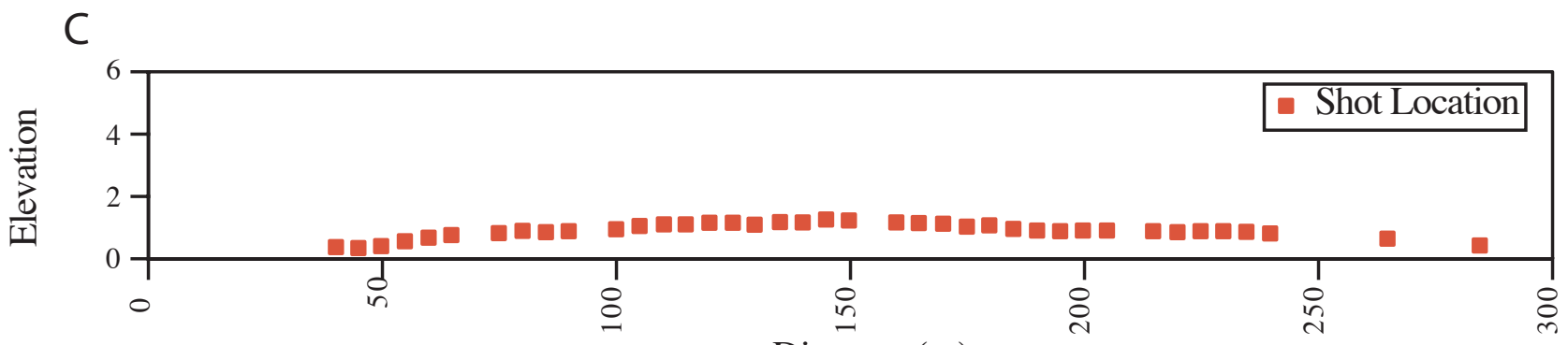

Distance (m)

D

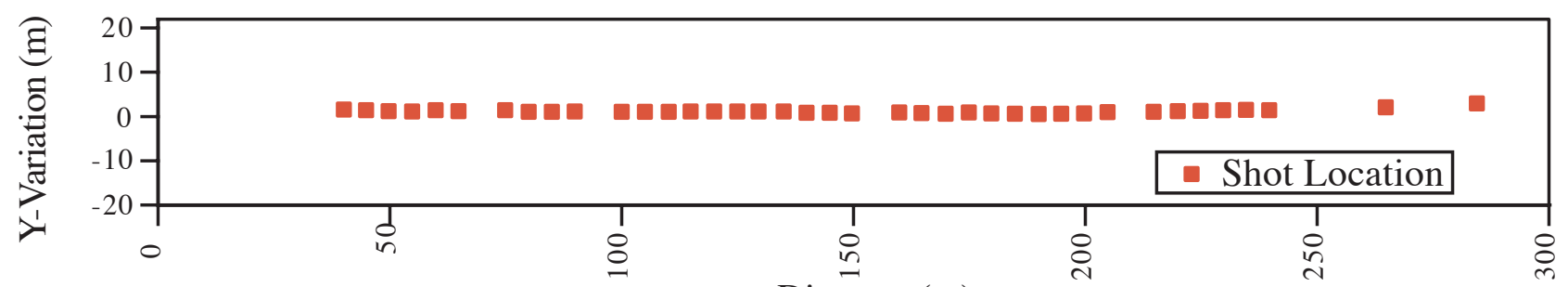

Distance (m)

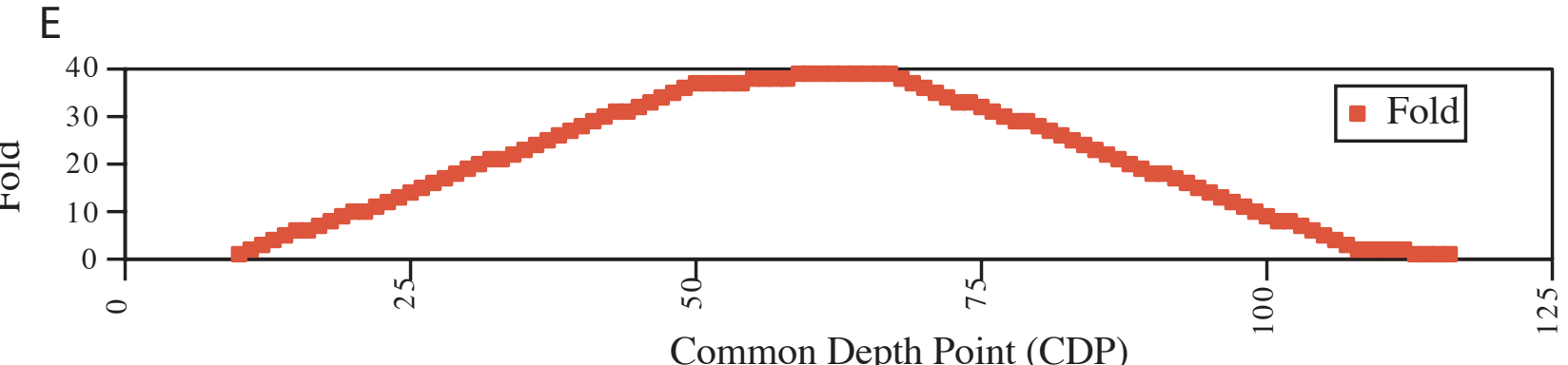

Fig. 7 


\section{Profile SL-6}

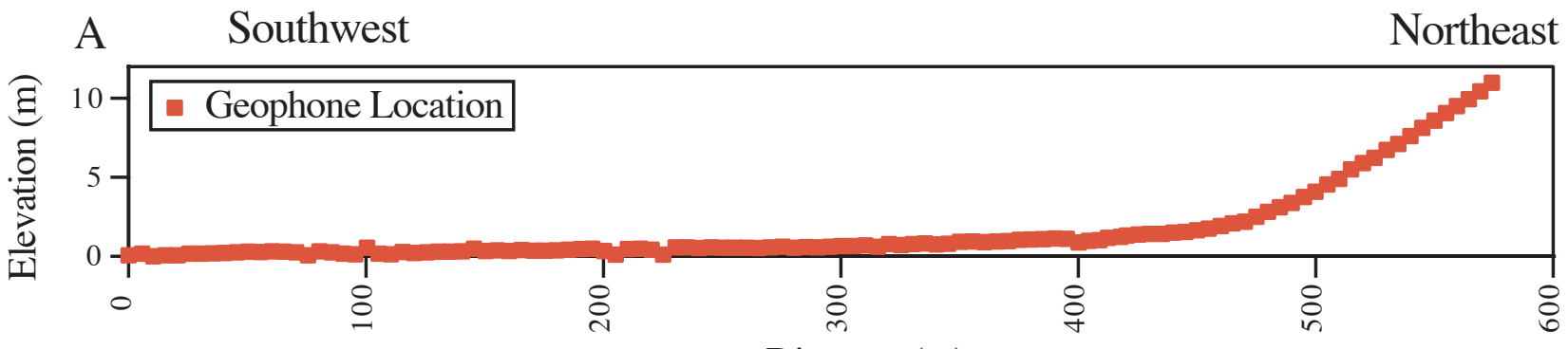

Distance (m)

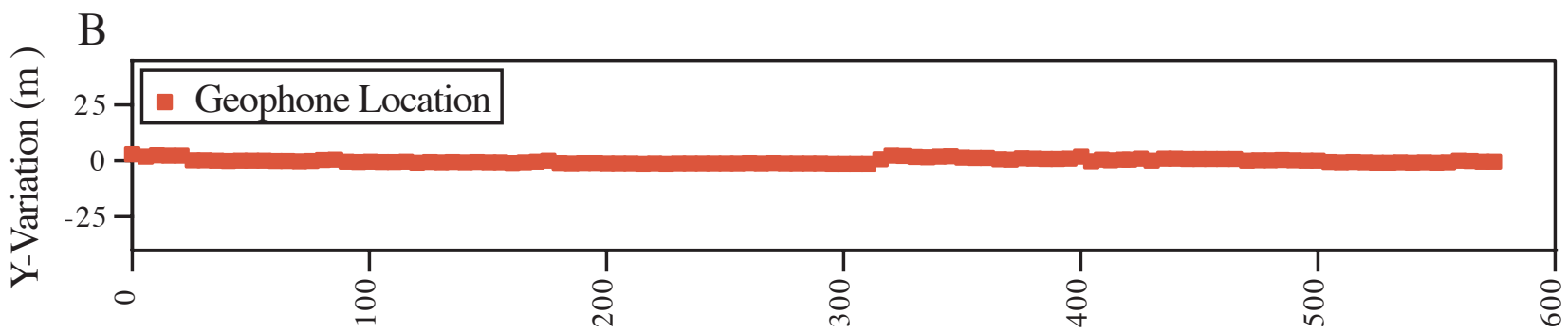

Distance (m)

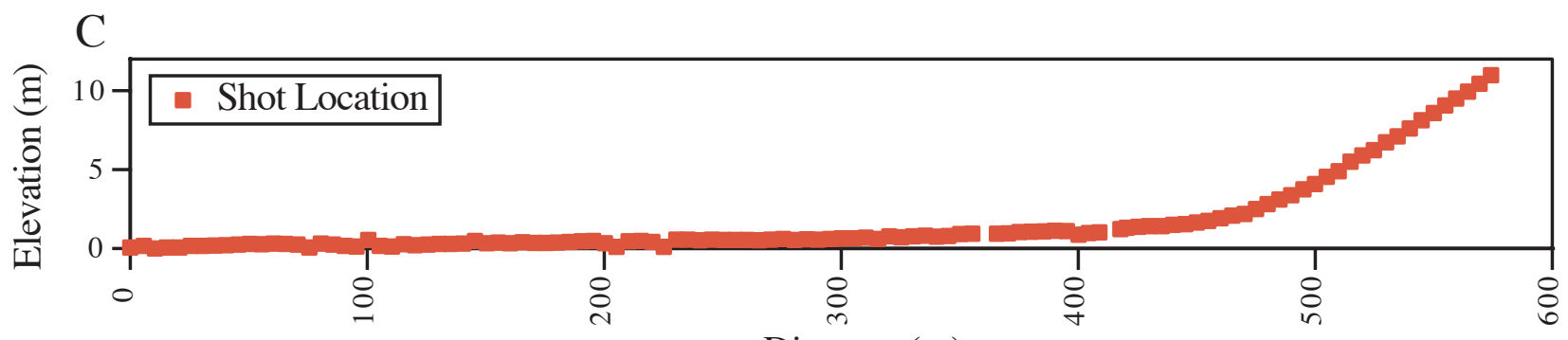

Distance (m)

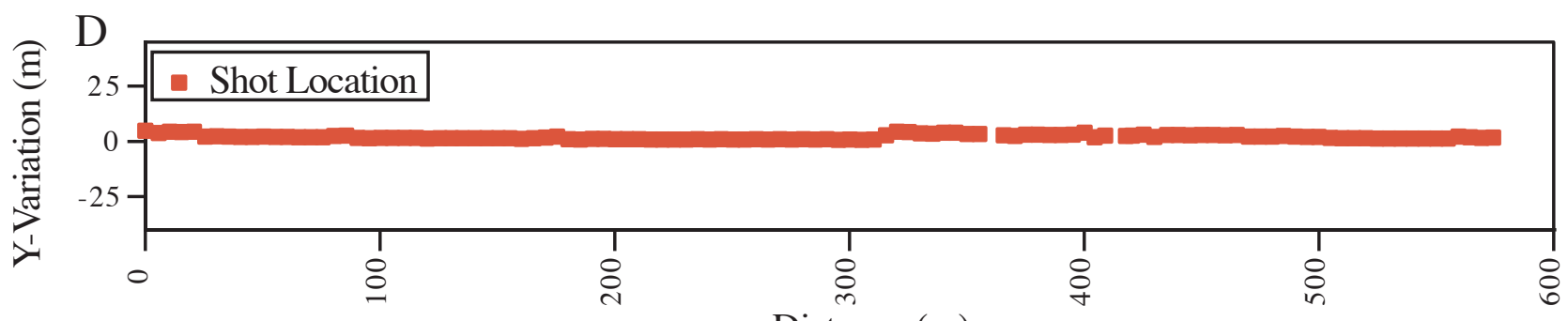

E

Distance (m)

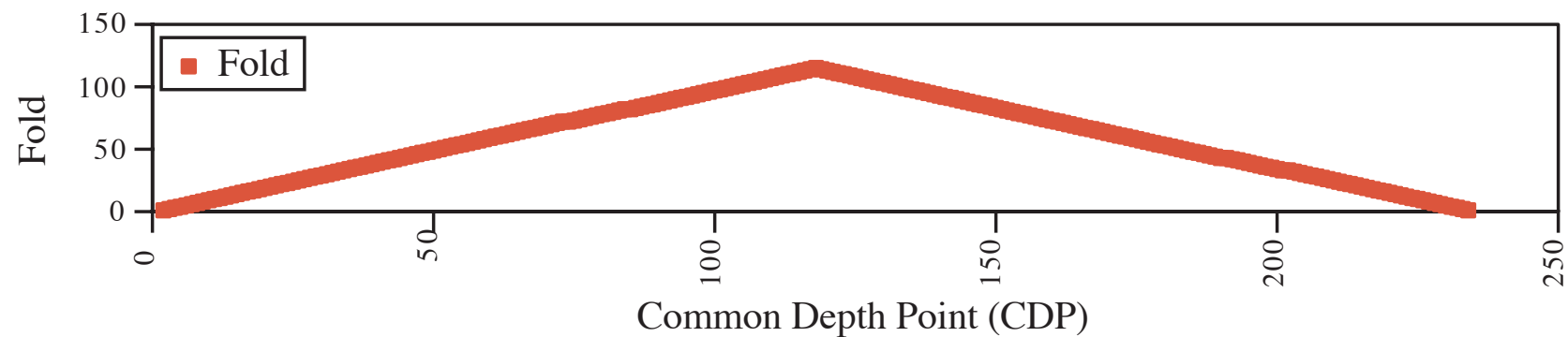

Fig. 8 
Figure 9 is an oversize illustration and is a separate file.

View Figure 9 as a 68" x 13" file (of2006-1084_fig09.pdf; 2.6 MB) 
Figure 10 is an oversize illustration and is a separate file.

View Figure 10 as a 46" x 20" file (of2006-1084_fig10.pdf; 14.3 MB) 
Figure 11 is an oversize illustration and is a separate file.

View Figure 11 as a 68" x 16" file (of2006-1084_fig11.pdf; 9.3 MB) 

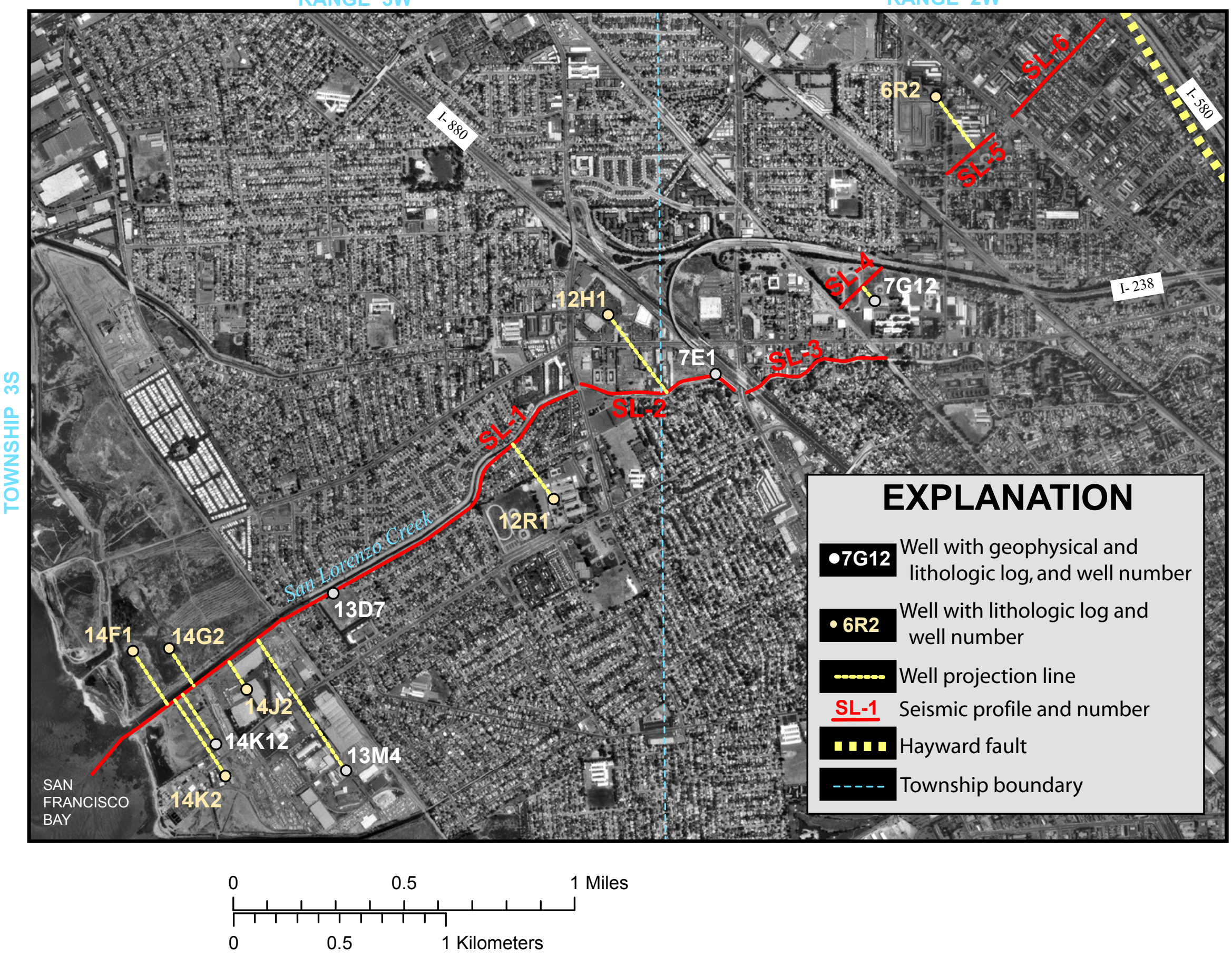

Figure 12. 
Figure 13 is an oversize illustration and is a separate file.

View Figure 13 as a 70" x 16" file (of2006-1084_fig13.pdf; 14.3 MB) 

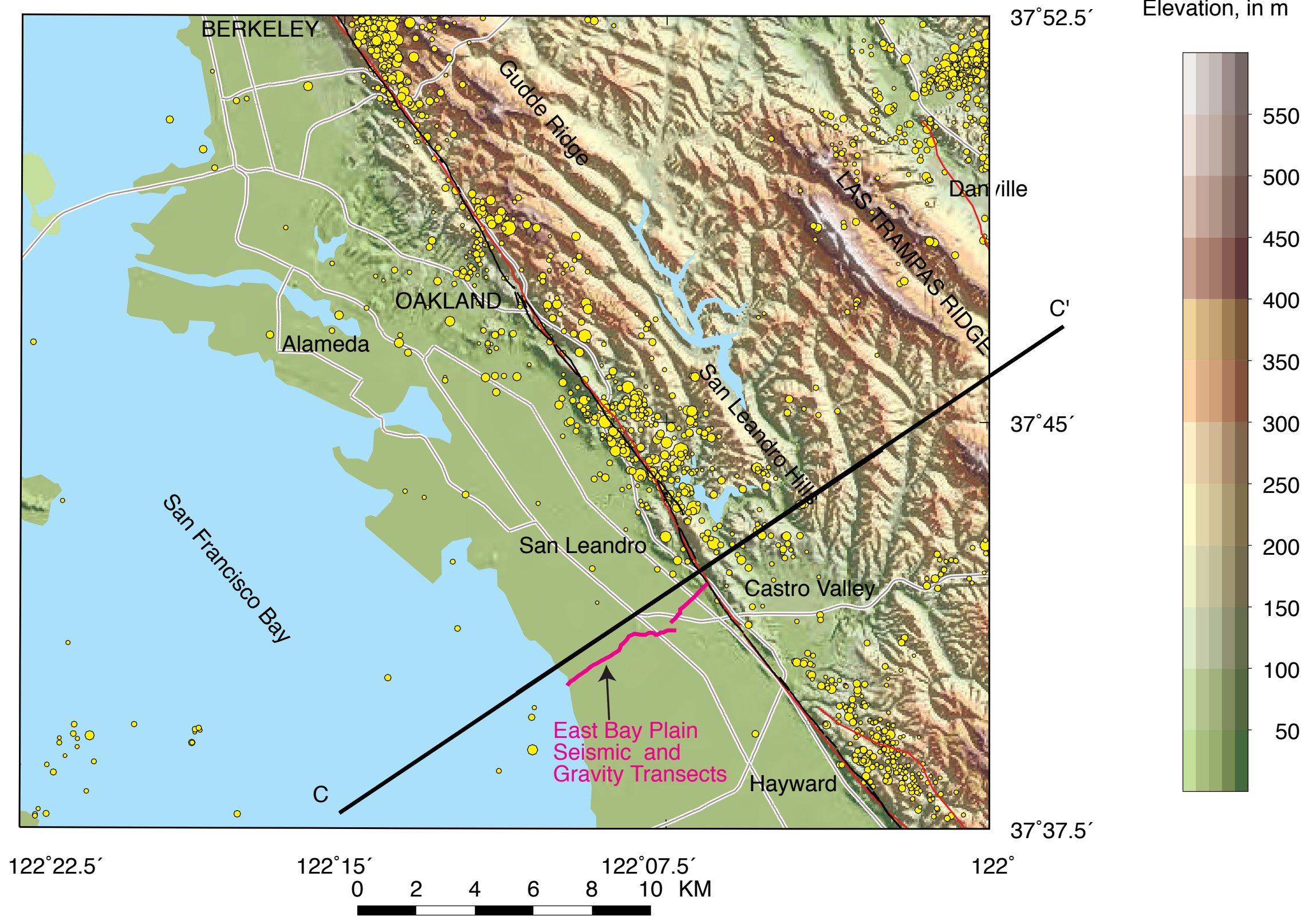

Fig. 14 
A Southwest

Northeast
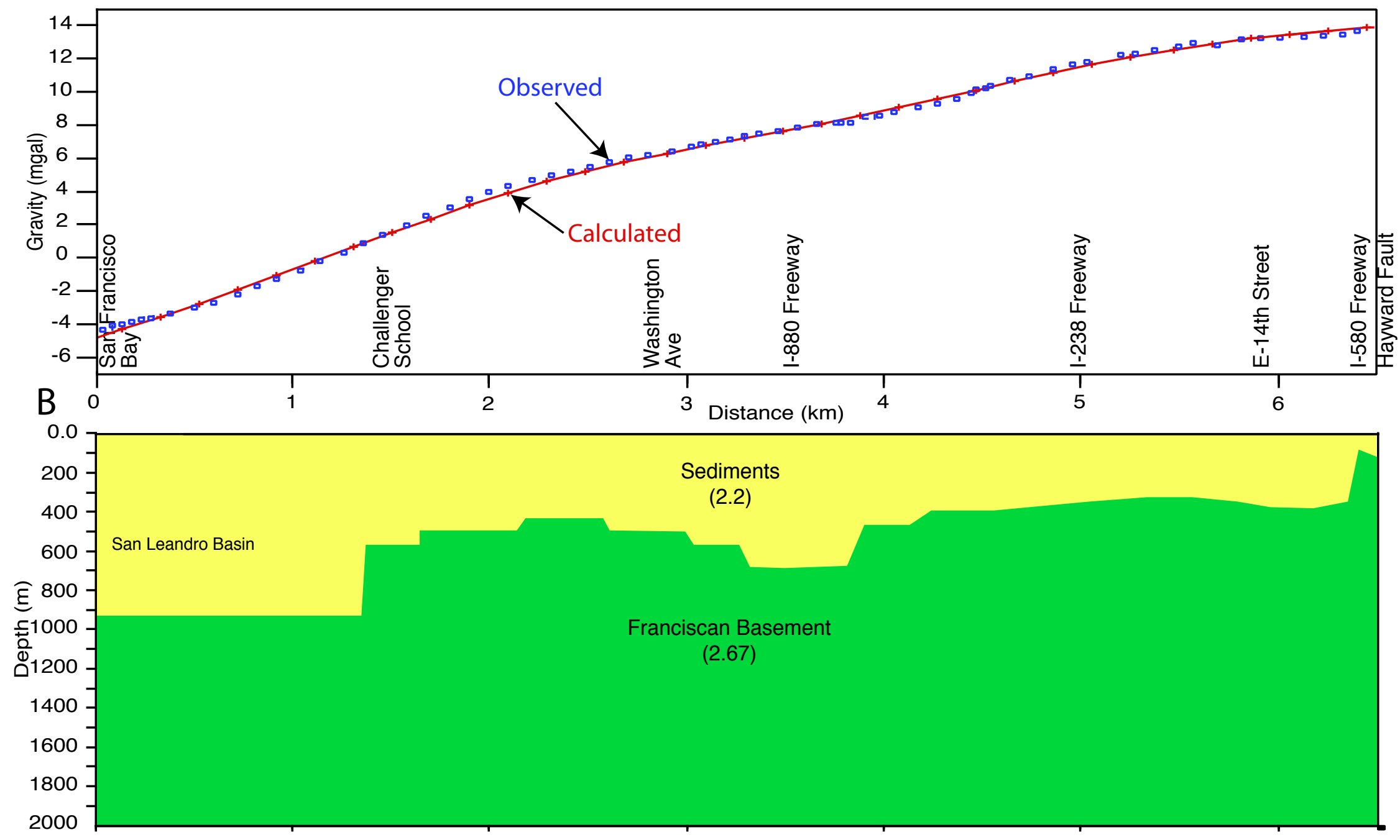

Fig. 15 


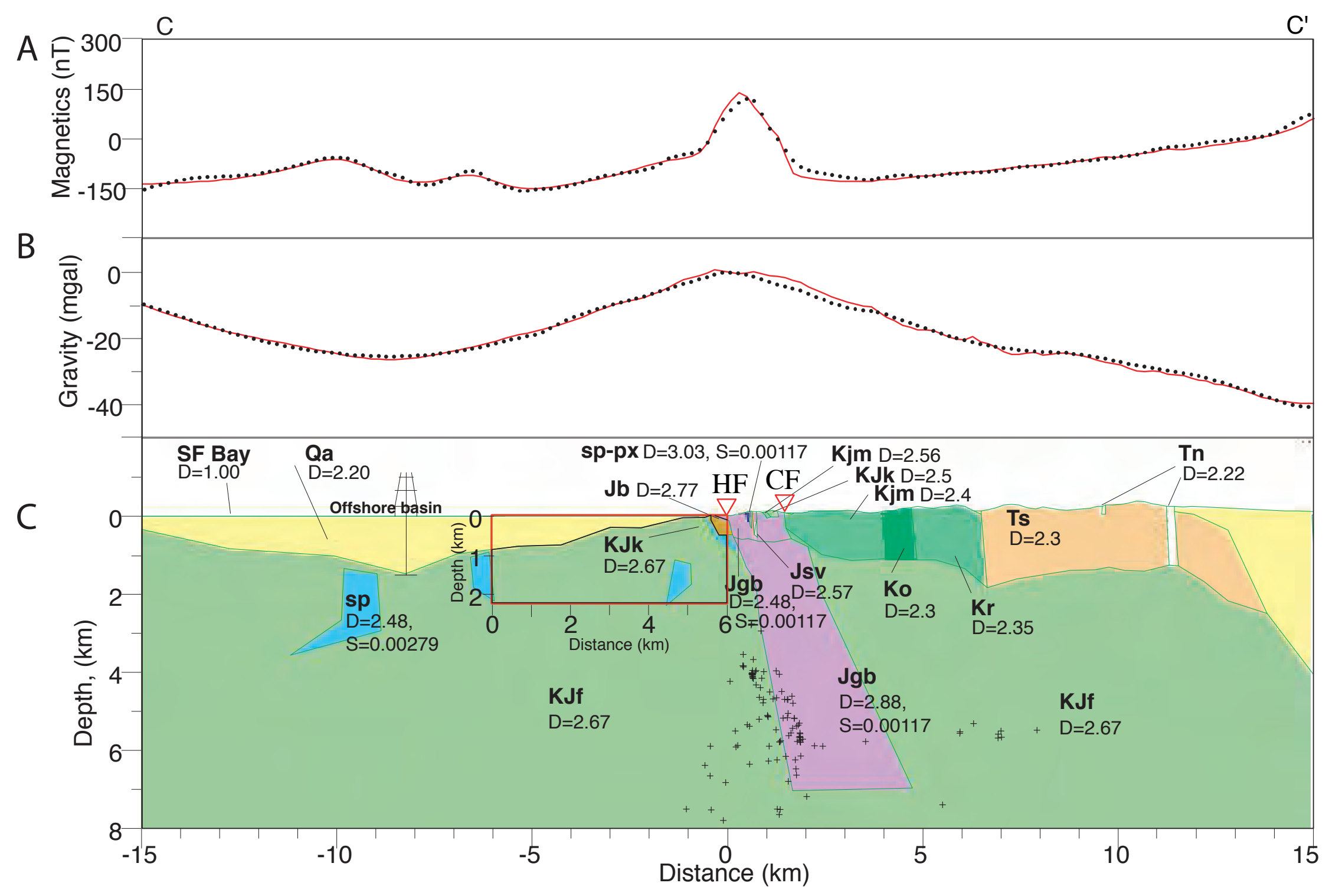

Fig. 16 
Figure $17 \mathrm{a}$ is an oversize illustration and is a separate file.

View Figure 17a as a 46" x 20" file (of2006-1084_fig17a.pdf; 35.1 MB) 


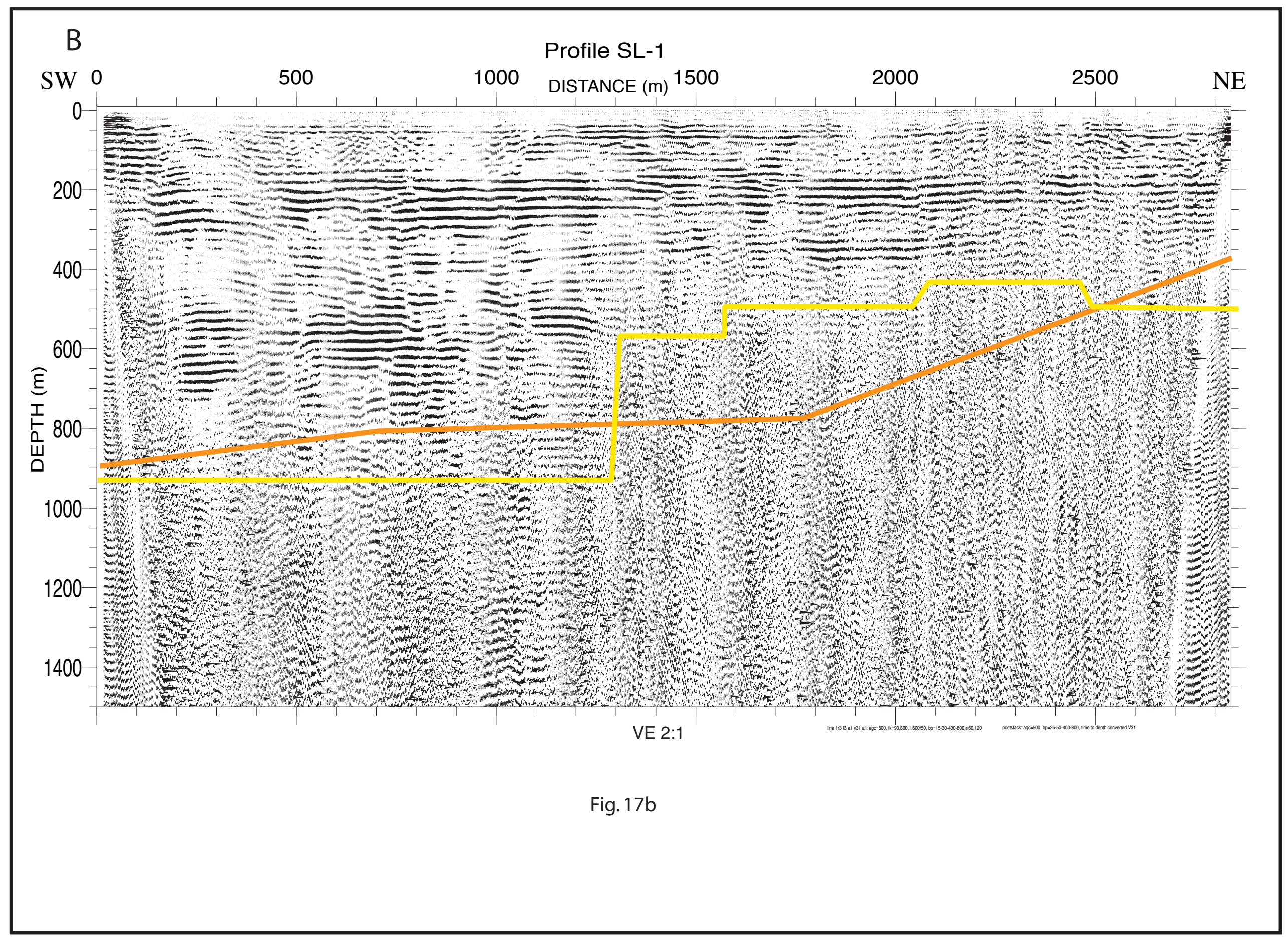




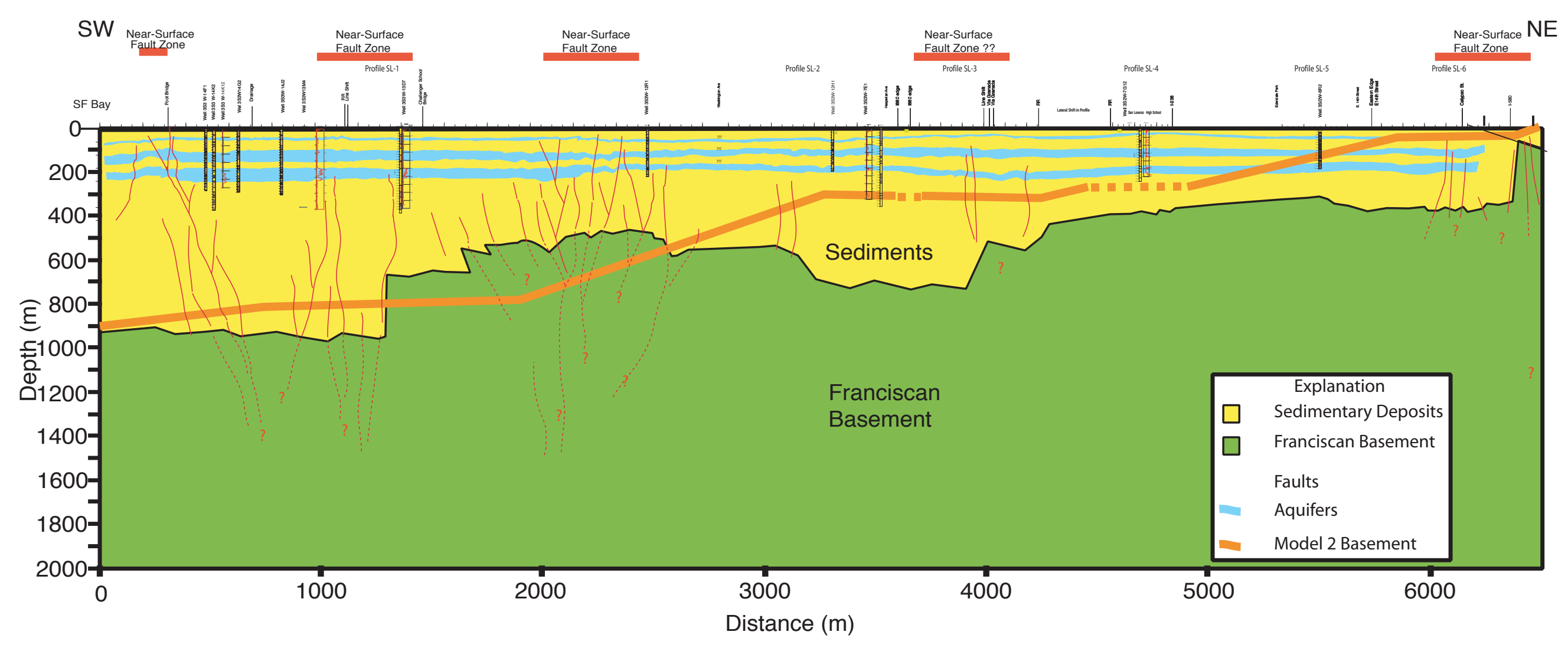

Fig. 18 
Figure 19 is an oversize illustration and is a separate file.

View Figure 19 as a 70" x 17" file (of2006-1084_fig19.pdf; 15.8 MB) 

Figure 21 is an oversize illustration and is a separate file.

View Figure 21 as a 50" x 20" file (of2006-1084_fig21.pdf; 16 MB) 


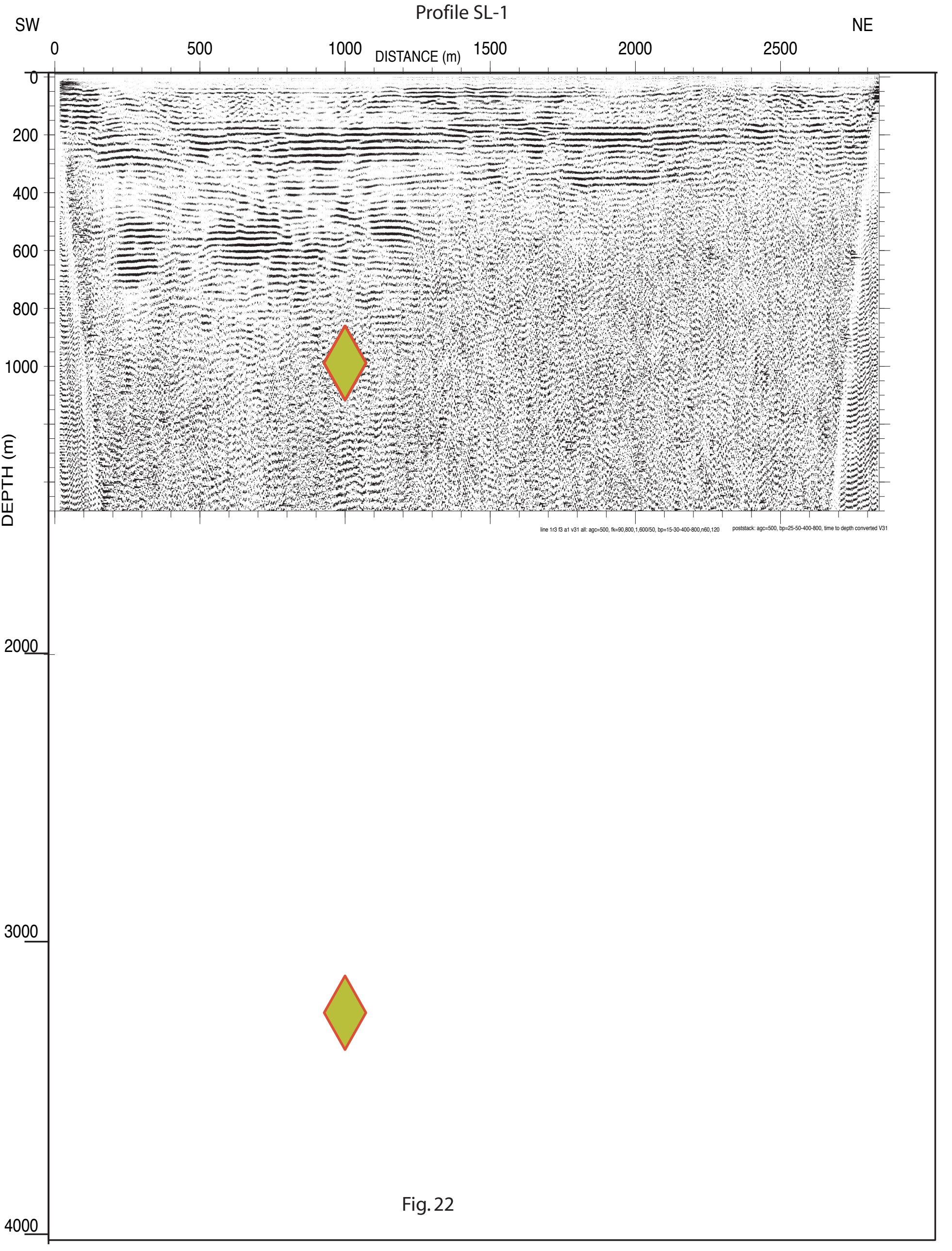

